Florida International University FIU Digital Commons

$11-1-2011$

\title{
Filtering the International Gender Paradigm: Perspectives of Gender in Barbados
}

Astrid Ellie Hurley

Florida International University, aelli004@fiu.edu

DOI: $10.25148 /$ etd.FI11120212

Follow this and additional works at: https://digitalcommons.fiu.edu/etd

\section{Recommended Citation}

Ellie Hurley, Astrid, "Filtering the International Gender Paradigm: Perspectives of Gender in Barbados" (2011). FIU Electronic Theses and Dissertations. 546.

https://digitalcommons.fiu.edu/etd/546

This work is brought to you for free and open access by the University Graduate School at FIU Digital Commons. It has been accepted for inclusion in FIU Electronic Theses and Dissertations by an authorized administrator of FIU Digital Commons. For more information, please contact dcc@fiu.edu. 


\title{
FLORIDA INTERNATIONAL UNIVERSITY \\ Miami, Florida
}

\section{FILTERING THE INTERNATIONAL GENDER PARADIGM: PERSPECTIVES OF GENDER IN BARBADOS}

\author{
A dissertation submitted in partial fulfillment of the \\ requirements for the degree of \\ DOCTOR OF PHILOSOPHY \\ in \\ INTERNATIONAL RELATIONS
}

by

Astrid Soyini Natasha Ellie Hurley

2011 
To: $\quad$ Dean Kenneth Furton

College of Arts and Sciences

This dissertation, written by Astrid Soyini Natasha Ellie Hurley, and entitled Filtering the International Gender Paradigm: Perspectives of Gender in Barbados, having been approved in respect to style and intellectual content, is referred to you for judgment. We have read this dissertation and recommend that it be approved.

Clair Apodaca

Chantalle Verna

Gail Hollander, Co-Major Professor

Patricia Price, Co-Major Professor

Date of Defense: November 1, 2011

The dissertation of Astrid Soyini Natasha Ellie Hurley is approved.

\begin{tabular}{r}
\hline $\begin{array}{r}\text { Dean Kenneth Furton } \\
\text { College of Arts and Sciences }\end{array}$ \\
\hline Dean Lakshmi N. Reddi \\
University Graduate School
\end{tabular}

Florida International University, 2011 
(C) Copyright 2011 by Astrid Soyini Natasha Ellie Hurley

All rights reserved 


\section{DEDICATION}

I dedicate this dissertation to my little brother, Dwight, the inspiration behind pursuing a $\mathrm{PhD}$, and to my daughter, Jenesis, the new beginning that emboldened me to finish it. 


\section{ACKNOWLEDGMENTS}

As a spiritual person, I give thanks first for my intellectual talents, and for the opportunities afforded me to hone the skills necessary to apply those talents in a meaningful way.

I give thanks for the funding received from Florida International University (FIU), in the form of Graduate Assistantships and scholarships, which made my PhD pursuit possible. I am thankful also for the depth and scope of my educational experience at FIU.

I give thanks for the inspiration and direction given me by the professors with whom I have had the pleasure to work in pursuit of my degree. Thank you, Dr. Ken Boodhoo for showing me that it was okay to "stay close to home" in my area of specialization. Thank you, Dr. Gail Hollander for showing me that it was okay to be guided by my heart and, in this way, inspiring the focus of my work. Thank you, Dr. Patricia Price, for "stoking the fire" on those many occasions when I was running out of steam, and for being such an excellent model of scholarly professionalism. Thank you, Dr. Chantalle Verna and Dr. Clair Apodaca for agreeing to come on board in the race for the finish and exercising the flexibility that you did.

I give thanks for the love and support of my family, without whom this dissertation would still be a fleeting thought. Thanks to my dad, Tony, for the head start. Thanks to my sister, Sophia, my mum, Marcilene, my uncle, Devere, and my "El Paso parents,"

Carolyn and Curtis, for the financial and emotional support. Thanks also to my loving husband, Roderick, for his time, positive energy and editorial assistance that helped me to make it to the end. 


\section{ABSTRACT OF THE DISSERTATION \\ FILTERING THE INTERNATIONAL GENDER PARADIGM: PERSPECTIVES OF \\ GENDER IN BARBADOS}

by

Astrid Soyini Natasha Ellie Hurley

Florida International University, 2011

Miami, Florida

Professor Gail Hollander and Professor Patricia Price, Co-major Professors

My work presents a place-specific analysis of how gender paradigms interact

across and within spatial scales: the global, the regional, the national and the personal. It briefly outlines the concepts and measures defining the international gender paradigm, and explores the filtration of this paradigm into assessments and understandings of gender and gender dynamics by and within Barbados. It does this by analyzing the contents of reports of the Barbados government to international bodies assessing the country's performance in the area of gender equality, and by analyzing gendercomparative content of local print news media over the decade of the 1990s, and the first decade of the 2000s. It contextualizes the discussion within the realm of social and economic development. The work shows how the almost singular focus on "women" in the international gender paradigm may depreciate valid gender concerns of men and thus hinder the overall goal of achieving gender equality, that is, achieving just, inclusive societies. 


\section{TABLE OF CONTENTS}

CHAPTER

PAGE

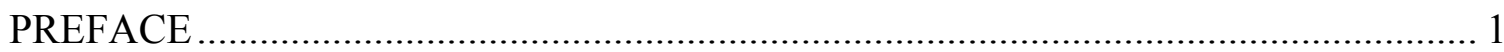

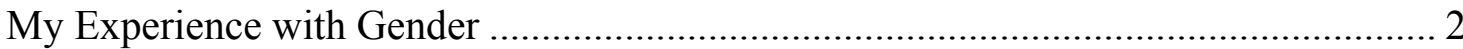

Because I Am a Girl, I Was Favored.................................................................. 2

Because I Am a Girl, Education Was Paramount...................................................... 4

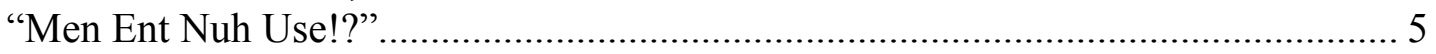

Because I Am a Girl, I Felt Free .................................................................... 7

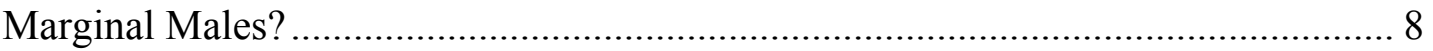

Significance of the Work: Filtering the International Gender Paradigm ....................... 9

Presenting the Barbados Case: Structure of the Work ................................................. 11

I. GENDER PARADIGMS: THE INTERNATIONAL STANDARD AND THE

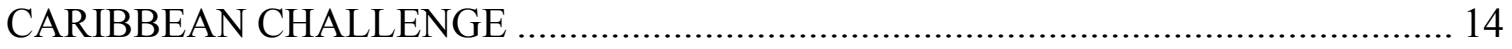

The International Paradigm: A Brief Historical Overview ……………....................... 14

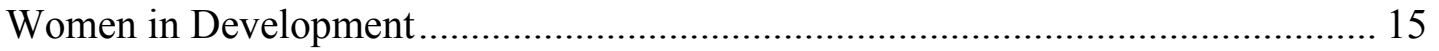

A Shift to Gender Relations? ................................................................................. 16

Monitoring Implementation of the International Paradigm: International Instruments

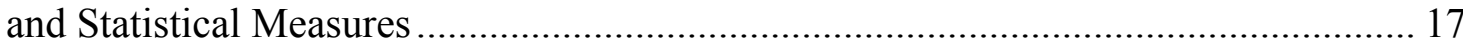

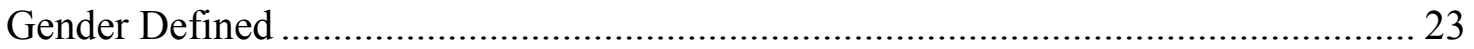

Challenging the Paradigm: The Caribbean Debate …………....................................... 24

Understanding the Gaps: The Need for Further Exploration ......................................... 30

II. IMPLEMENTING THE GENDER PARADIGM: GENDER AND DEVELOPMENT

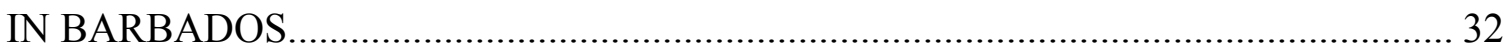

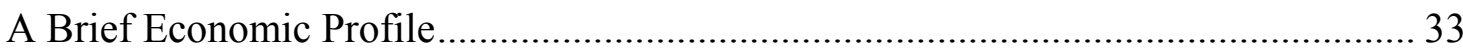

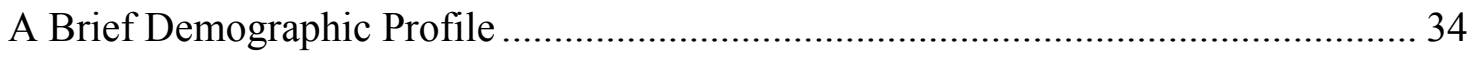

Human Development...................................................................................... 35

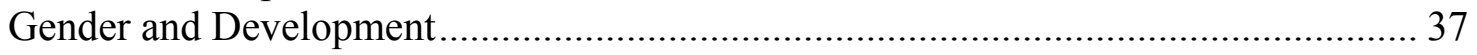

International Commitments and Domestic Action.................................................. 43

Social Status and Gender Policy in Barbados …………....................................... 48

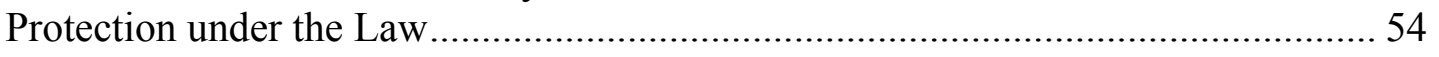

Gender Policy and Education ................................................................................. 55

Gender, Employment and Wages ………………………..................................... 56

Gender Policy and Political Participation.................................................................. 57

Conclusion: The Barbadian State and the International Gender Paradigm................... 59

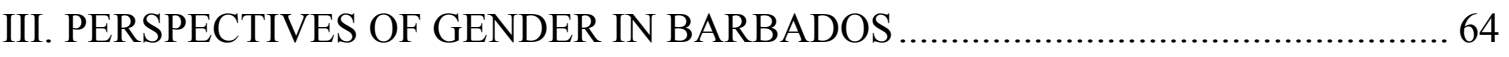

Sourcing Public Perspectives: Mining the Media ………............................................. 64

Perspectives on Feminism and the Women's Movement .......................................... 68

Perspectives of Gender and Society in Barbados........................................................... 69

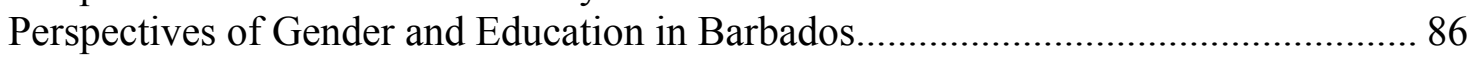

Perspectives of Gender and Employment in Barbados ................................................ 91 
Perspectives of Gender and Policy in Barbados

Conclusion: The Perceived Gender Dynamic in Barbados.......................................... 100

IV. SOCIOECONOMICS AND GENDER IN BARBADOS: REALITY AND

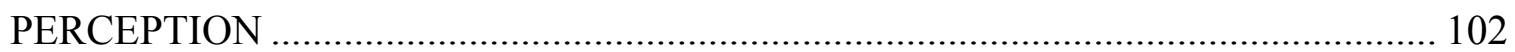

The SES Focus of Gender and Development: Outlining the Paradigm ...................... 103

Gender and Education in Barbados: The Facts ......................................................... 105

Gender and Employment in Barbados: Reality and Perception................................ 118

Gender on the Political Front ........................................................................... 132

Conclusion: Does the Reality of Barbadian Gender Dynamics Match the Perspectives

Observed at the State and Local Levels? ................................................................... 134

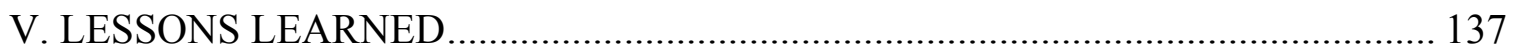

The International Gender Paradigm is About Women............................................. 138

Filtering the International Gender Paradigm: Unequal Application .......................... 139

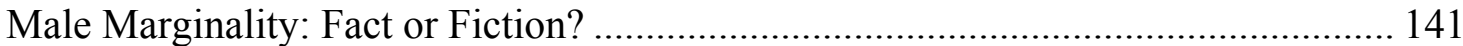

Leveraging the Lessons Learned ......................................................................... 142

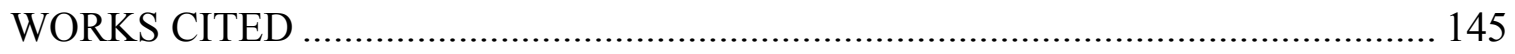

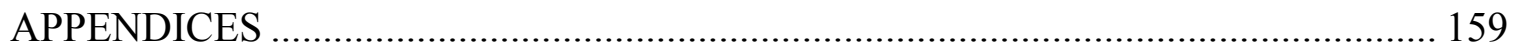

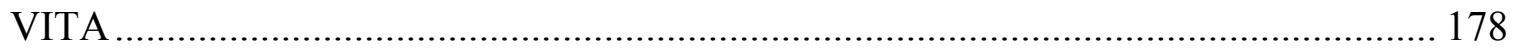




\section{LIST OF FIGURES}

FIGURE

PAGE

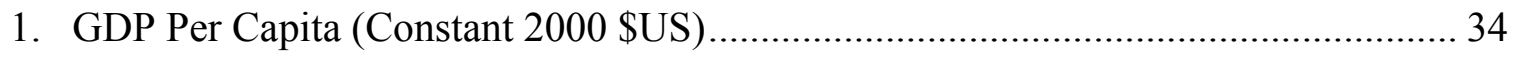

2. Barbados Trends in Human Development (Measured as HDI) ............................... 37

3. Barbados Trends in Gendered Human Development and Women's Empowerment

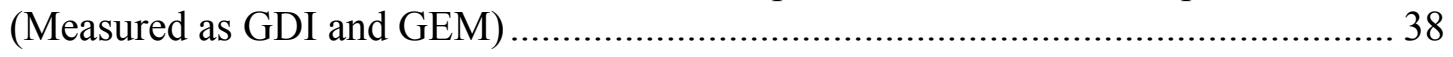

4. Barbados Trends in Gendered Human Development (Measured as GDI) ................ 39

5. Barbados Trends in Women's Empowerment (Measured as GEM) ......................... 39

6. Barbados Trends in Male and Female Life Expectancy, 1995-2007 ....................... 41

7. Barbados Trends in Male and Female Literacy Rates, 1995-2007 ......................... 41

8. Barbados Trends in Male and Female Combined Enrollment Ratios, 1995-2007 ..... 42

9. Male and Female Estimated Earned Income, 1997-2007 .................................... 42

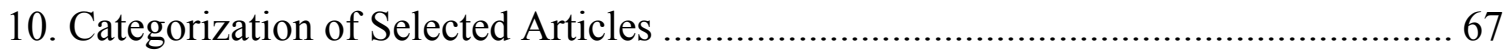

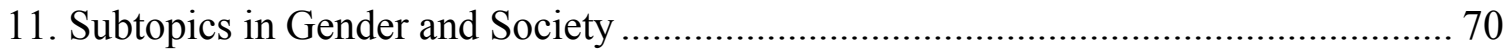

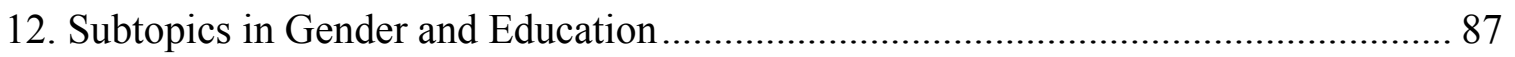

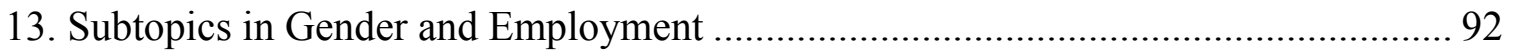

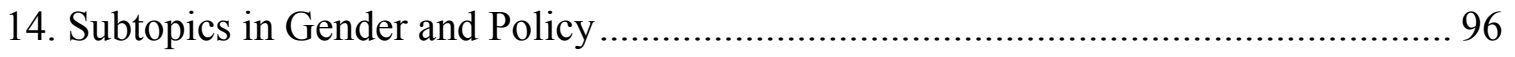

15. Male and Female Shares in Public Secondary Education Compared to Shares in

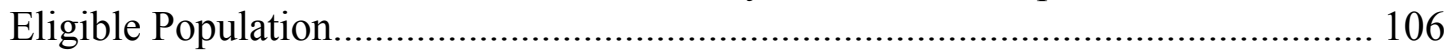

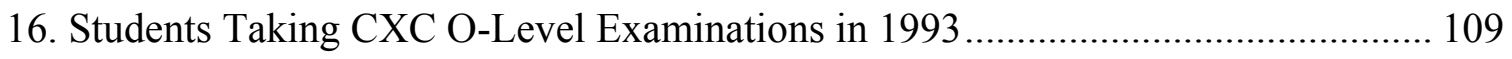

17. Students Taking General/Technical Proficiency CXC Examinations in 1993 ......... 109

18. CXC Exam Passes at General/Technical Proficiency in 1993, by Sex................... 110

19. Proportion of Exam Takers Attempting each Exam Category in 1993, by Sex ...... 110

20. Passing Rate at General/Technical Proficiency in 1993, by Sex .......................... 110 
21. Proportion of Total Exam Takers Achieving Passes at General/Technical Proficiency

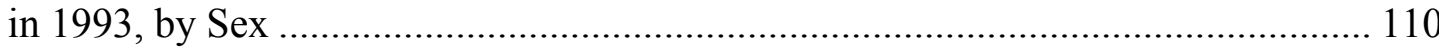

22. Students Taking CXC O-Level Examinations in 2003 ......................................... 112

23. Students Taking General/Technical Proficiency CXC Examinations in 2003 ......... 112

24. CXC Exam Passes at General/Technical Proficiency in 2003, by Sex.................... 112

25. Proportion of Exam Takers Attempting each Exam Category in 2003, by Sex ....... 112

26. Passing Rate at General/Technical Proficiency in 2003, by Sex ............................. 113

27. Proportion of Total Exam Takers Achieving Passes at General/Technical Proficiency

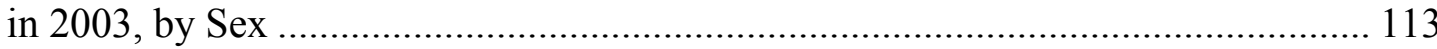

28. Students Taking CXC O-Level Examinations in 2009.......................................... 114

29. Students Taking General/Technical Proficiency CXC Examinations in 2009 ......... 114

30. CXC Exam Passes at General/Technical Proficiency in 2009, by Sex..................... 114

31. Proportion of Total Exam Takers Achieving Passes at General/Technical Proficiency

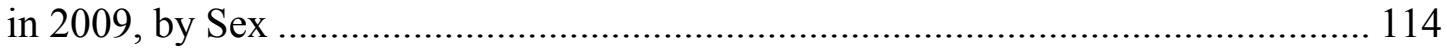

32. Passing Rate at General/Technical Proficiency in 2009, by Sex .............................. 115

33. Proportion of Total Exam Takers Achieving Passes at General/Technical Proficiency

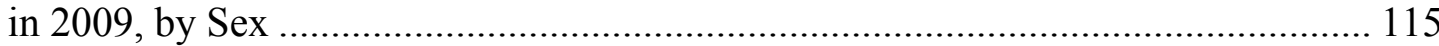

34. Total Tertiary Enrollment 1990-2008 ……………........................................... 116

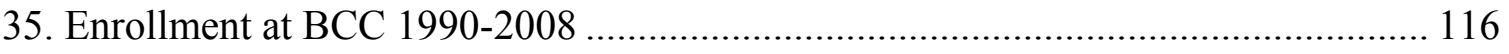

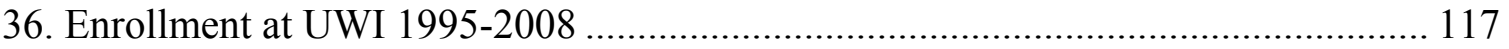

37. Enrollment at Erdiston Teachers' College 1995-2008 …........................................ 117

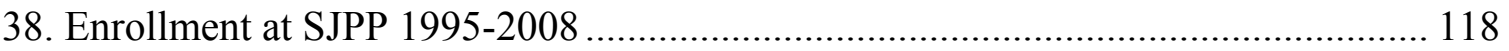

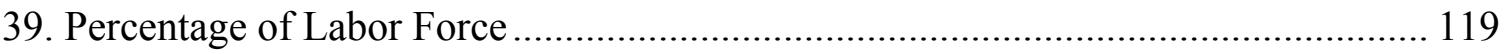

40. Labor force Participation for Ages 15+ by Sex ...................................................... 120 
41. Unemployment Rates 1980-2008 by Sex ……………....................................... 121

42. Male Employment by Economic Activity .......................................................... 126

43. Female Employment by Economic Activity ……………..................................... 127

44. Employment Activity as a Share of Total Employment .......................................... 128

45. Employment Activity as a Share of Employment (by sex)................................... 129

46. Economic Activity as a Share of GDP............................................................. 130

47. Proportion of Total Employment by Occupation and Sex...................................... 131

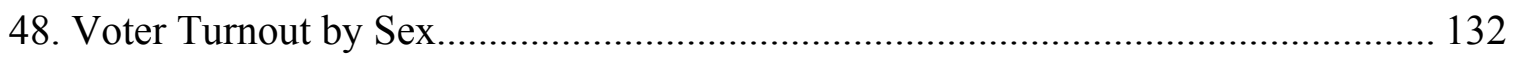

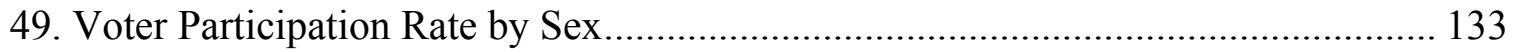




\section{LIST OF ABBREVIATIONS}

$\begin{array}{ll}\text { BBD } & \text { Barbados Dollars } \\ \text { BCC } & \text { Barbados Community College } \\ \text { BEC } & \text { Barbados Employers' Confederation } \\ \text { CARICOM } & \text { Caribbean Community } \\ \text { CEDAW } & \text { Convention on the Elimination of All Forms of Discrimination against } \\ & \text { Women/Committee on the Elimination of All Forms of Discrimination } \\ \text { CXC } & \text { Caribbean Examination Council } \\ \text { ECLAC } & \text { United Nations Economic Commission for Latin America and the } \\ \text { FIU } & \text { Caribbean } \\ \text { GA } & \text { Florida International University } \\ \text { GAOR } & \text { General Assembly (United Nations) } \\ \text { GDI } & \text { General Assembly Official Records (United Nations) } \\ \text { GDP } & \text { Gender Development Index } \\ \text { GEM } & \text { Gross Domestic Product } \\ \text { GII } & \text { Gender Empowerment Measure } \\ \text { GNI } & \text { Gender Inequality Index } \\ \text { HDI } & \text { Gross National Income } \\ \text { HDR } & \text { Human Development Index } \\ \text { ILM } & \text { International Legal Materials } \\ \text { IMF } & \text { International Labour Organization } \\ & \text { International Monetary Fund } \\ & \end{array}$


LABORSTA International Labour Organization Database on Labour Statistics

MDGs Millennium Development Goals

MESA Men's Educational Support Association (Barbados)

NACG National Advisory Council on Gender (Barbados)

NCSW National Commission on the Status of Women (Barbados)

NOW National Organization of Women (Barbados)

OECD Organization for Economic Cooperation and Development

SAR Special Administrative Region

SES Socioeconomic Status

SJPP Samuel Jackman Prescod Polytechnic (Barbados)

UN United Nations

UNDP United Nations Development Programme

UNESCO United Nations Economic, Scientific and Cultural Organization

UNICEF United Nations Children's Fund

UNIFEM United Nations Development Fund for Women

UNTS United Nations Treaty Series

USD United States Dollars

UWI University of the West Indies

WAMM Meeting of Commonwealth Ministers Responsible for Women's Affairs

WID Women in Development 


\section{PREFACE}

I began my studies in International Relations at Florida International University, in 2002, with a keen interest in how global social policy informs and is informed by the lived experiences of everyday people. As part of my studies, I was exposed to feminist theorizing on the construction of gender identity and the concept of gender dynamics, and how these did and can affect development policy at all levels from the individual to the national. ${ }^{1}$ I found myself in a situation of dissonance, sensitive to what I perceived as a paradigm which framed gender dynamics as limited femininity versus dominant masculinity, because, though I could see where it might apply in some spaces, in some places, I could not quite fit my own experience within this frame. I was also sensitive to the fact that this dominant paradigm was the benchmark against which the level of development of countries, like my own, is judged at an international level, and as such, it is this paradigm that would most likely inform national action and responses to perceived shortcomings and raised concerns in the area of gender dynamics. I began to wonder how these two realities interacted with each other in shaping the "everyday" of females and males in my country, and what lessons, if any, might be learned from seeking to outline this interaction. As such, my work both maps and interprets the contents of this dissonance. An understanding of my own experience with gender - my own mental framing of gender dynamics - is thus a necessary foundation to an appreciation of my work.

\footnotetext{
${ }^{1}$ While the concept of development policy is most readily understood as a documented course of action, procedure and/or regulation of government or other decision-making institution, it can also be understood as the guiding principles habitually used by individuals and groups in their decision-making processes.
} 


\section{My Experience with Gender}

\section{Because I Am a Girl, I Was Favored}

I was born and raised on the island of Barbados, a small country in the Eastern Caribbean, born of mercantilism and plantation slavery. I was born into a low-income family. My mum was a self-employed dressmaker, working from home, and my father a porter at the island's commercial dairy. I was the third of my mother's children and the first of my father's. Between my mum and my dad, they were five of us, two girls and three boys, but one of my father's sons, the one a year younger than I, lived with his mum in another part of the island, in a neighborhood very similar to mine. Being of a workingclass household and Afro-Caribbean ethnicity, I fell into the majority. As a female, I also belonged to the more populous sex. Most things that defined me were pretty typical, especially in my neighborhood, the largest government housing scheme on the island. The one atypical characteristic of my composition, especially for my class and color, was that I lived with both my mum and dad, and they were married. Most other people I knew, though not estranged from their fathers, lived with their mum, an aunt, grandmother, godmother, or some combination of these.

My father only ever wanted a daughter, and it was obvious. I could expound on the details but my brothers would probably prefer that I did not. This preference for female children, or at least first-born females, is actually not that uncommon in Barbados, especially among the working class. Girls are seen as less trouble, more responsible,

more focused and, frankly, more useful (Lynch-Foster 2004, Quinlan 2006,The Barbados Advocate 2009). Of course, as a child, I never questioned the source of this perception. I 
never thought twice about how this perception shaped my "everyday," nor that of the males around me; I just rolled with it, living it in both expected and unexpected ways.

The position of favor, which I experienced, transcended my home, which is how I knew it was not something unique to my family and me. I saw it played out most often at school. In fact, I must admit I sometimes used it mischievously to evoke a sense of "girl power" in my 'tween years. Around age nine our ten, (around 1990), I noticed that our school headmaster began to stress the boy-girl interactions very much. He instituted a new rule that any boy who hit a girl would be punished (get lashes), regardless of the reason. He said this was because boys, who were becoming young men, needed to learn to be fair to girls and treat them with respect. I always found this rule quite laughable, not because of the lesson it tried to teach, but because of the seemingly skewed assessment of fairness that it embodied. At this age, most of us girls were bigger than our male classmates, and a few of us were much bigger. By age ten, I was about five feet plus two or three inches, weighed approximately 100 pounds and was renowned in my year group for my strength (especially when angry). I was not the tallest. There were many other girls in my year group, about four in my class alone, who were taller than I was. When this rule came into play, the four or five of us big girls in my class began to make mischief with it. We became a body guard gang of sorts, taking on any boy that dared to upset any girl in our class. We would chase him down, steal his shoes, rough him up, anything to provoke a tussle, and then revel in the plethora of lashes he would receive versus our more lenient punishment, while he was lectured on the proper way for a young man to conduct himself in a dispute with a lady. 
I also remember teachers always expecting girls to be smarter than boys and I also remember taking that to heart. Throughout both elementary and secondary school I was in the "first stream" class (the class of top-skilled students in English and mathematics). In most cases, girls made up the majority of students in my class. The top student in my class was always a female, and the most challenged was always a male. For me that was just the normal course of things, and I never even really stopped to consider what came between. In elementary school, I was that top student, and my closest competition was usually my best friend, Beverly. However, I do remember once, in Class 2 (age 8 or so), when I got second position in Mathematics and was much dismayed by the taunting I received from teacher and classmates alike because a boy, my friend Damian, had beat me to the top. I also remember that when it was time to move on to secondary school, girls had to score more than boys to get into the top-ranked schools so that the numbers of girls and boys would be equal.

\section{Because I Am a Girl, Education Was Paramount}

"Try and go to school and learn, so you don't have to depend on no man. 'Cause when yuh eat soldier man bread yuh have to tek soldier man blows, and no man ent to mek you no maid." These are the words of my mother. This particular warning held high rank among those that were constantly repeated to me throughout the years. Roughly interpreted, she was telling me that education was the route to financial independence and freedom from obligatory and even possibly harmful relationships. The characteristics of financial independence and the assumed strength and power this brings, are elements highly associated with being a successful woman in the Barbadian context, and across the Anglophone Caribbean. At least that was how I experienced it. 
Some of this seemed to stem from a general idea that it is easier for men to find income outside of formal business circles, the idea that boys could find some means to get by, while a girl needed to secure "employment." It was not okay for a girl to be not interested in school, nor to leave school without some kind of qualification. This was seen as dooming oneself to dependence and obligation. Boys on the other hand could be "not into to the school thing" as they could always find some kind of "labor work" or "work with their hands." Girls could work with their hands too - needle work, cooking, light electronics - but even these handy girls were encouraged to seek some kind of certificate so they could pursue these talents within mainstream employment. So there was definitely some corralling of labor force expectations and consequently, income pursuits, but I never felt like it was putting me at some disadvantage to my brothers or the other males around me. In fact, I felt like it was giving me a one-up really.

\section{“Men Ent Nuh Use!?”}

Most of the women around me, and even some of the men, seemed to ascribe a general worthlessness and redundancy to men, one that seemed to be fed by a rift between economic expectations and reality. I remember a conversation with a male friend of mine, back in 2003, where we shared or thoughts on the comparative roles of men and women in Barbados. He was 23 at the time, and a Master's student in the field of Engineering. He described Barbadian society as more dependent on the female role, and referred to Barbadian men as stagnant and complacent, while suggesting that Barbadian women were naturally progressive and responsible. I can't ever forget his synopsis of the role of Barbadian men, that is, they "breed and get fed." I always wondered if he ever stopped to question his defeated assessment of what our society expected of him. 
Research on the political economy of gender dynamics in the domestic sphere in Barbados and the wider Anglophone Caribbean also suggests that women have tended to maintain families because of men's and women's labor market experiences. Researchers have argued that, for women in the Caribbean, including Barbados, the economic options afforded them meant (and increasingly means) that an unemployed or marginally employed man is a drain on resources, and therefore, the household would do better without him (Morrissey 1998).

Even with these admonitions, however, I still never got the sense that men were assigned to some second-class status. It was quite the paradox actually. These "useless" men were still ascribed with some level of privilege. Boys could be outside more, while girls had to make sure they took time to mind their studies. Boys also had the privilege of feeling a bit less moral pressure. Girls were expected to fit into a Christian moral mold, especially with regard to sexual behavior. This moral expectation waned once you became economically independent because, at this point, you were able to take care of any children you might bear as a "consequence" of stepping out of this mold. Both girls and boys were given domestic chores, but girls were usually given more care responsibilities for younger brothers and sisters, where they existed. Males were also often ascribed a level of titular headship within their domestic relationships: head of the table, biggest share of food, more likely to get help with their chores. I say titular because this came across as such a front at times. Whenever I would ask my mother to make a decision on something, she would tell me to ask my father. He, in turn, would either ask me what my mother said, or ask my mother what the decision should be. And what a problem it would be if he made a choice for me of which my mum did not approve. 


\section{Because I Am a Girl, I Felt Free}

Despite the higher expectations for girls, I never once wished I were a boy. In a way, I felt like I had more freedom to just be; especially when it came to some of the subtler, more psychological aspects of life. I liked that my collection of toys could include tea sets, dolls, Spiderman and rocket ships and that it was just as okay for me to watch Thunder Cats as it was for me to watch My Little Pony. I could play "what the boys played," or play "what the girls played" depending on my mood, but it was only okay for boys to play like boys (at least voluntarily for any extended period). While it was okay for a girl to be a bit rough and tumble (which I was), a boy who was not was seen as some kind of deviant. Neat handwriting equaled writing like a girl, concern about tidiness equaled acting like a girl, preferring to stay inside and read equaled acting like a girl. No boy wanted to be known for acting like a girl because that made him less of a boy, and in fact, he may be called a girl by adults and peers alike - it questioned his sexuality. As a boy, unless you were going into hard science, business or some creative, skill-based pursuit you better be pursuing that other field as self-employed or a sidehustle, but to enter mainstream employment in fields other than these would be simply less than manly. On the other hand, as a female, these limitations did not apply in quite the same way. Though pursuit of more administrative, clerical and care-oriented fields was more expected, another pursuit did not necessarily undermine your feminine identity, it may shift what kind of girl or woman you were seen as (that is a whole other dimension of gender in Barbados for future exploration), but you were still a girl or woman. As my own interests changed throughout the years, I remember neighbors, females and males 
alike, envisioning my future employment as everything from writer to police officer, doctor, lawyer and politician.

\section{Marginal Males?}

By the time I started my matriculation at FIU, I had been exposed to an on-going public debate in Barbados, and the wider Caribbean, on the social and economic status of men. Politicians, academics and the general public were imbued in discussions on male marginalization - the idea that men were being systemically disadvantaged and that the greater political attention being paid to females was partly to blame. While some thought the existence of male marginalization to be blatantly obvious, others surmised the rising discussion of the phenomenon as a response born of fear of lost privilege by males who now found themselves competing with females on equal terms. My introduction to feminist theories and gender dynamics within international development, and the resulting dissonance, made me even more sensitive to this debate. Although I never agreed with all the arguments I could certainly identify with many of them. I would think of my brothers, who were always being compared to their sisters, intellectually, developmentally and behaviorally. I thought of my household and all the others around me in which the focal point, the real head, was a woman. I thought of the domestic, social and economic roles that women played and the many responsibilities that they had. I thought about the very few male teachers I had encountered, of the many female doctors, lawyers, coaches and other professionals that had interacted with me and my family. I thought of how I seldom saw men at work in the stores in the city, or as the tellers in the banks, or in any of the other places of business that may be frequented on the day-to-day. I thought about the female Governor General in place in my teen years, 
the popular female politicians, present throughout my lifetime, who seemed to always have something to say about everything that passed through the House of Parliament, and so many other leading female figures to whom I had grown accustomed. Of course these thoughts did not blind me to the fact that the Prime Minister had always been male or that there were no female faces on our money, or that even though my mum did most of the domestic and economic work in our household she always expected us to assign some kind of titular headship to my father. So I thought on these things and I wondered: with all the increased attention on the rights and empowerment of women, where do men fit into society; where does society see them as fitting; and where do they see themselves as fitting?

\section{Significance of the Work: Filtering the International Gender Paradigm}

From this sea of thought has emerged the work before you. It tries to map the contents of these thoughts in a more linear way, in the hopes of unmasking the links and gaps between how gender was and is lived by me and those around me and what I came to learn about the international gender paradigm, as a way of framing and making sense of these experiences. The work takes a feminist constructivist perspective, in its recognition of gender as a social identity "constructed, defined and maintained in discourse and culture and sustained through institutional practices," and sees these discursive, cultural and institutional contexts of gender as an intersection between global and local ideas, ideals and practices (McDowell 2003, 12).

Though the pursuit is personal in its origins, its usefulness transcends the hopeful dissolution of my dissonance. The work presents a place-specific analysis of how gender paradigms interact across and within spatial scales: the global, the regional, the national 
and the personal. At the national and regional levels, this kind of work is particularly useful for informing the policy approach to gender and gender dynamics. In Barbados and the wider Anglophone Caribbean, the debate over male marginalization has been ubiquitous. At the sixth Annual Meeting of the Commonwealth Ministers Responsible for Women's Affairs (WAMM) participants noted that more research is needed to understand the effect of contemporary changes in the global society on men. The report of the sixth annual WAMM suggested that though available empirical data may undermine the theory of male marginalization, the widespread perception of male marginalization, particularly in education, could negatively affect gender-mainstreaming programs (Commonwealth Secretariat 2000). In Barbados, the Bureau of Gender Affairs has similarly verbalized a need for research on men's perceptions of themselves as well as their placement in society, so that gender-focused policies can more adequately address the needs of both men and women and thus be more effective in creating gender equality.

Barbados provides a fitting case for examining the Caribbean challenge to the international gender paradigm. The country has shown itself as a bastion of social and economic stability in the region, having performed quite consistently in measures of socioeconomic status over the years. At the same time, Barbados has remained culturally consistent with its Caribbean neighbors, having a shared history of European domination, plantation economics and African slavery, as well as a common demographic constitution and economic trajectory; however, Barbados has moved along its development trajectory at a faster and more consistent rate than most of its regional counterparts. Barbados has also been a consistent hot spot in the debate on male crisis, across the ranks of policy, 
academia and public opinion. As such, examining social structures in Barbados within its Caribbean context provides simultaneously a glimpse of what is and what could be with regard to gender and development within the region.

Because the social and economic effects of global restructuring, as well as gender equality policies, have affected men and women across the globe, the importance of conducting this type of place-specific research also transcends the Barbadian and Caribbean contexts. In exploring the Barbados case my works seeks to present a context of convoluted gender relations as insight into the importance of avoiding dichotomous presentations of gender within development policy and processes. It also provides insight into how the assumptions and expectations spawning and spawned from these policies and processes are filtered into or up from, everyday dynamics. In addition, by examining the gendered experience of male social development alongside that of females, it hopes to contribute to a reframing of the international gender paradigm that assigns greater consideration for exploring and acknowledging how sex-based inequalities may negatively target men, and how this in turn affects the overall goal of just, inclusive development.

\section{Presenting the Barbados Case: Structure of the Work}

My work presents the perspectives of gender and gender dynamics in Barbados by exploring the framing of gender and gender dynamics within state-level discourse, academia and public opinion throughout the past two decades. It seeks to contextualize the debate within the realm of social development.

Chapter I presents the contents of the international gender paradigm through review of academic literature, major international instruments and agreed development 
goals. It also explores the way this paradigm has filtered into the Caribbean regional context of which Barbados is a part.

Chapter II introduces the Barbadian context by looking at the course of social development and gender equality in Barbados and how this trajectory has related or interacted with the international development paradigm. It then explores the state-level response to the expectations of the international gender paradigm by mining its reports to the international bodies concerned with monitoring state action in the achievement of gender equality.

Chapter III then presents the public discourse on gender throughout the 1990s and into 2010 and discusses its relationship to the international paradigm and state-level response. It proceeds with this exploration through analysis of media discussion on the topic. In so doing, this chapter presents the perspectives of gender and gender dynamics within Barbadian society. It shows the assumed reality of gender dynamics by those who live it - the perceived "placement" of male and female gender within daily living.

Chapter IV of my work then seeks to unearth the socioeconomic/objective factors which feed and/or refute the perceptions presented in Chapter III. This chapter uses data on socioeconomic status (education, labor market status and income) along with some exploration of political participation, to present the material relations of gender within the society.

In concluding, Chapter V draws together these explorations by highlighting the overlaps and gaps across the dominant perspectives of gender and gender dynamics at each spatial scale. It also draws out lessons learned, in showing how this exploration can be drawn upon in informing the discourse on gender and development across other 
contexts, particularly the international gender paradigm. In so doing, my work makes a valuable contribution to ensuring effective gender-focused strategies for achieving inclusive societies. 


\section{GENDER PARADIGMS: THE INTERNATIONAL STANDARD AND THE}

\section{CARIBBEAN CHALLENGE}

\section{The International Paradigm: A Brief Historical Overview}

The terms gender and gender empowerment have found use in the international development discourse as concepts rooted in feminist academic discourse. Influenced heavily by the actions and research of feminist activists and economists, proponents of women's inclusion fought for decades to have the specific needs of women recognized at all levels, local, national and international.

In 1970, Danish economist Ester Boserup issued a marked challenge to the way that international development and the distribution of development aid were aimed. In analyzing women's roles in agricultural production, Boserup's work highlighted the marginalization of women in the development process and the failure of the dominant development paradigm in accounting for their contributions. Boserup also highlighted the failure of the development paradigm to account for different value systems throughout the world and hence the need to infuse moral and ethical reasoning into the development approach. It is through the raising of these moral and ethical questions, and through the examination of existing value systems and structures, that women's roles and needs could be explored and accommodated.

The work of Ester Boserup invigorated the international women's movement. Beginning in the United States, proponents of women's development began to use the work to get their governments to institute policy changes that would advance women's interests. This second wave of feminism in the United States aimed to have women 
recognized as valuable economic contributors in their own right, and gained a level of national and international media and economic following that led to the first wave of official feminism within international development research and policy (Tinker, 2004). The "Women in Development" approach was born.

\section{Women in Development}

The Women in Development approach (WID) did not question the general theory driving the development process. Fueled by the perspectives of liberal feminism, the WID approach subscribed to modernization theory and the economic approach to understanding development, but challenged the targets of development aid and other benefits. According to WID, the democratic and egalitarian societies that the modernization paradigm aimed to produce could only come through ensuring that women were adequately integrated into development as workers and producers, and not relegated to the domestic, or private, sphere. Women in Development aimed to make development planners and policymakers at the international and national levels see women as real and valuable contributors to the economy. The movement held at its core the belief that while most women around the world worked, the economic value of their work was overlooked because, although it often added value to production, it was often unpaid. As such, this approach further elaborated on the notion of women as an oppressed class of its own. By improving the visibility of women, proponents of this approach hoped that women's needs and concerns would be accounted for within development thought and policy, and that the rampant inequities that they faced would thus be addressed.

Fed by the international women's movement, WID had a significant effect on the shape of international development dialogue. The movement led to the United Nations 
International Women's Decade (1976-1985) and to a growing prominence of women's issues on the United Nations agenda. Four World Women's Conferences were held, Mexico City (1975), Copenhagen (1980), Nairobi (1985) and Beijing (1995), each further highlighting the need for attention to women's roles and treatment within social and economic development paradigms, and each further elevating the role of the international women's movement and the prominence of feminist concerns in international politics (Visvanathan 1997). The outcome of the first World Women's Conference in 1975 called for a convention on the elimination of discrimination against women (United Nations 1976). As such the Convention on the Elimination of All Forms of Discrimination Against Women (CEDAW) was formulated within the Commission on the Status of Women in the United Nations, and became the rights-based international instrument at the core of gender related policy and practice emanating from the international gender paradigm. The Convention on the Elimination of All Forms of Discrimination Against Women entered into force on September 3, 1981, thirty days after being ratified by the twentieth state.

\section{A Shift to Gender Relations?}

With the fourth World Women's Conference in Beijing, the international gender paradigm took a notable shift in forwarding the concept of "gender relations" in development to highlight the unbalanced power relations that existed between men and women. The gender relations approach proposed that unbalanced power as the root of women's repressed position in development thought and processes and the source of their generally disproportionate shares of hardship and deprivation. The gender relations approach recognized the need to look at women's development in relationship to the rest 
of their lives and to the other persons and processes in their lives. As outlined by Charlton (1997), a gender relations perspective recognizes the relationship between women and development as a relationship dependent on how much power and influence women have. As such, gender relations focused on the recognition of women as an oppressed class of its own, but purported that their subordinate status could only be challenged through new approaches to understanding how societies worked, and how women came to be relegated to the roles and placements that they did (Reddock 1999).

So while the shift to a gender relations approach at the international level has popularized the terms gender, gender roles and gender relations, the general approach has remained constant: the focus is on women's roles, women's status and women's empowerment. The focus on these three elements aims to ensure that the output of development policy allows women to benefit. Though relational in concept, the international gender paradigm assigns very little focus to understanding and rooting out the beliefs, attitudes and ideals that may lead to the eventual unbalanced development between women and men. This is evidenced by the measures used to monitor state performance in the attainment of gender equality.

\section{Monitoring Implementation of the International Paradigm: International Instruments and Statistical Measures}

Within the body of international policy and practice, CEDAW and the related Beijing Declaration and Platform for Action, are central to the promotion of gender equality and women's empowerment and provides the main norms by which States are judged in their efforts at addressing gender in development. The Convention, which codifies women's rights as a specific category of human rights, is second only to the 
Convention on the Rights of the Child with regard to the level of support and acceptance, measured as ratification by member states of the United Nations. It has been ratified by more than ninety percent of UN membership (United Nations Development Fund for Women 2007). The premise behind CEDAW is that gender inequalities exist as a result of both systemic and unintentional discrimination against women (United Nations 1980). As such, CEDAW presents various areas of law and social practice that states should evaluate, change and/or develop to ensure that discrimination against women does not occur, and that women are experiencing substantive equality/equity. ${ }^{2}$

The Convention on the Elimination of All forms of Discrimination against Women consists of thirty Articles, with Articles 6 through 16 outlining the areas of attention for states with regard to eliminating negative discrimination toward women. The Convention addresses the elimination of trafficking in women and the exploitation of prostitution, the participation of women in public and political life, the participation of women in international affairs, women's nationality/citizenship rights, access to and experience of education, access to and treatment in employment, health care, women's economic and social life, the treatment and opportunities of rural women, equality before the law, and equality in marriage and family life. The Convention also outlines basic means by which states would be expected to address these issues. Under Articles 2 and 3, states parties are required to take all appropriate measures to address systemic discrimination against women, including the adoption of legislation. States parties are also encouraged to undertake temporary, targeted programs or projects aimed at bringing

\footnotetext{
${ }^{2}$ For a discussion on "substantive equality" or "equity" see Rosenfeld, Michel (1986), "Substantive Equality and Equitable Opportunity: A Jurisprudential Appraisal," California Law Review, Vol. 74, No. 5, pp. $1687-1712$
} 
women and men on par in institutional access and social and economic opportunities and outcomes. Under the provisions of CEDAW, states are also expected to address gendered socialization and stereotypes, requiring states parties to institute measures that would modify the "social and cultural patterns of conduct of men and women" so as to eliminate prejudices and stereotypes, along with any ideas of inferiority or superiority of the sexes. The Convention also encouraged states to provide family education and to promote maternity as a social function, as well as the shared responsibility of men and women in childcare and child rearing.

The Beijing Declaration and Platform for Action was adopted in September 1995 at the Fourth World Conference on Women held in Beijing, China (United Nations 1995). It arose from a concern that despite the attention brought to women's rights by the implementation of CEDAW and further conceptual commitments, there had not been satisfactory progress in the achievement of equality for women. As such, the Beijing Declaration and Platform for Action sought to harmonize and reaffirm the commitments to the various Conventions and Declaration outlining conceptual foci for achieving equality for women. These Conventions and Declarations included CEDAW, the Nairobi Forward-looking Strategies for the Advancement of Women (1985), the Declaration on the Right to Development (1986) and the Declaration on the Elimination of Violence against Women (1993).

The Platform for Action set out concrete points of action for governments, civil society and the international community to address twelve critical areas of concern. These twelve areas of concern are: persistent and disproportionate poverty among women, inequalities and inadequacies in the access and experience of education, 
inequalities and inadequacies in the access and experience of health care and related services, violence against women, the effects of all forms of conflict on women, the effect on women of inequalities in economic structures and policies, power imbalances between men and women at all decision-making levels, lack of mechanisms to promote the advancement of women, lack of respect for and inadequate promotion of the human rights of women, stereotyping of women within and their lack of access to systems of communication such as mass media, gender inequalities in natural resource management and environmental protection, and persistent discrimination against and violation of the rights of the girl child.

These areas of concern have become engrained within the wider development agenda, informing many of the targets and measures used in the monitoring and implementation of social and economic development around the world. For example in 1995, the Human Development Report of the United Nations Development Programme introduced two measures of human development to highlight the status of women: the Gender Development Index (GDI) and the Gender Empowerment Measure (GEM). ${ }^{3}$

The GDI disaggregated the performance of males and females within the same measures used to calculate the Human Development Index, which is the main measure of the human development approach used by UNDP in assessing a country's stats of development. ${ }^{4}$ The GDI falls if the achievements of either males or females fell, or if the disparity between the two genders increased. The GDI to HDI ratio of a country would thus indicate the extent of gender imbalance within human development. The GEM

\footnotetext{
${ }^{3}$ The Human Development Report (HDR) is the most widely cited development publication of the intergovernmental international organizations (Wagstaff 2011).

${ }^{4}$ The HDI is discussed further in Chapter II.
} 
measured gender inequality by looking at economic participation and decision-making, political participation and decision-making, and power over economic resources.

In its 2010 iteration, the HDR used a measure of gender equality termed the Gender Inequality Index (GII). Seen as an upgrade and response to the critiques of the previously used GDI and GEM, the GII looks at reproductive health (measured as maternal health and adolescent fertility), empowerment (measured as parliamentary representation, and educational attainment at and above the secondary level), and labor market participation (Gaye, and others 2010).

Similar issues have also been taken up within the Millennium Development Goals (MDGs), the leading paradigm currently shaping the international development agenda. The MDGs are drawn from the action oriented elements of the Millennium Declaration, adopted during the United Nations Millennium Summit in 2000. There are eight key goals, each with specific targets of implementation and measurable indicators. Of these eight goals, two speak directly to issues of gender equality: Goal 3 (Promote Gender Equality and Empower Women) and Goal 5 (Improve Maternal Health). The targets and indicators of Goal 1(Eradicate Extreme Poverty and Hunger) and Goal 2 (Achieve Universal Primary Education) also orient them toward a gender equality perspective.

The table, which follows, provides a quick overview of the gender-specific elements of the MDGs: 


\begin{tabular}{|c|c|}
\hline \multicolumn{2}{|c|}{$\frac{\text { Overview of the Gender-specific elements of the MDGs (United Nations Statistics }}{\text { Division 2008) }}$} \\
\hline $\begin{array}{c}\text { Goals and Targets } \\
\text { (from the Millennium Declaration) }\end{array}$ & Indicators for monitoring progress \\
\hline \multicolumn{2}{|l|}{ Goal 1: Eradicate extreme poverty and hunger } \\
\hline $\begin{array}{l}\text { Target 1.A: Halve, between } 1990 \text { and } 2015 \text {, the } \\
\text { proportion of people whose income is less than one } \\
\text { dollar a day }\end{array}$ & $\begin{array}{l}\text { 1.1 Proportion of population below } \\
\$ 1 \text { (PPP) per day } \\
\text { 1.2 Poverty gap ratio } \\
\text { 1.3 Share of poorest quintile in } \\
\text { national consumption }\end{array}$ \\
\hline $\begin{array}{l}\text { Target 1.B: Achieve full and productive } \\
\text { employment and decent work for all, including } \\
\text { women and young people }\end{array}$ & $\begin{array}{l}\text { 1.4 Growth rate of GDP per person } \\
\text { employed } \\
\text { 1.5 Employment-to-population ratio } \\
\text { 1.6 Proportion of employed people } \\
\text { living below \$1 (PPP) per day } \\
\text { 1.7 Proportion of own-account and } \\
\text { contributing family workers in } \\
\text { total employment }\end{array}$ \\
\hline $\begin{array}{l}\text { Target 1.C: Halve, between } 1990 \text { and 2015, the } \\
\text { proportion of } \\
\text { people who suffer from hunger }\end{array}$ & $\begin{array}{l}\text { 1.8 Prevalence of underweight } \\
\text { children under-five years of age } \\
\text { 1.9 Proportion of population below } \\
\text { minimum level of dietary energy } \\
\text { consumption }\end{array}$ \\
\hline \multicolumn{2}{|l|}{ Goal 2: Achieve universal primary education } \\
\hline $\begin{array}{l}\text { Target 2.A: Ensure that, by } 2015 \text {, children } \\
\text { everywhere, boys and girls alike, will be able to } \\
\text { complete a full course of primary schooling }\end{array}$ & 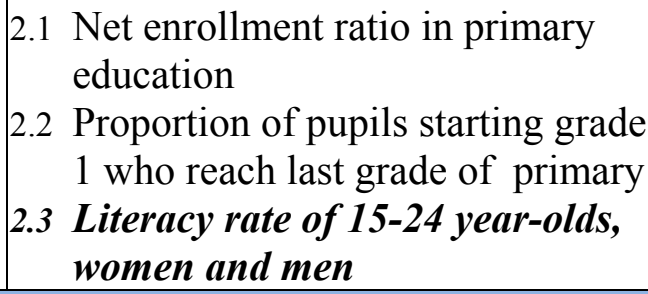 \\
\hline \multicolumn{2}{|c|}{ Goal 3: Promote gender equality and empower women } \\
\hline $\begin{array}{l}\text { Target 3. A: Eliminate gender disparity in primary } \\
\text { and secondary education, preferably by 2005, and } \\
\text { in all levels of education no later than } 2015\end{array}$ & 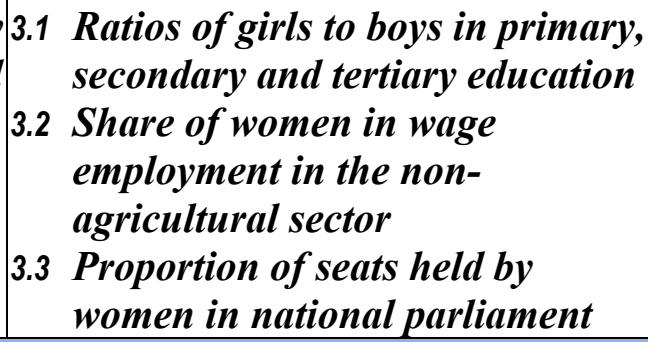 \\
\hline \multicolumn{2}{|l|}{ Goal 5: Improve maternal health } \\
\hline $\begin{array}{l}\text { Target 5. A: Reduce by three quarters, between } \\
1990 \text { and } 2015 \text {, the maternal mortality ratio }\end{array}$ & $\begin{array}{|ll|}5.1 & \text { Maternal mortality ratio } \\
5.2 & \begin{array}{l}\text { Proportion of births attended by } \\
\text { skilled health personnel }\end{array} \\
\end{array}$ \\
\hline $\begin{array}{l}\text { Target 5.B: Achieve, by 2015, universal access to } \\
\text { reproductive health }\end{array}$ & $\begin{array}{l}\text { 5.3 Contraceptive prevalence rate } \\
5.4 \text { Adolescent birth rate }\end{array}$ \\
\hline
\end{tabular}


Except for monitoring the issue of women's health, the international paradigm uses measures and indicators that use male performance as a standard against which to measure that of women. However, as forwarded by the gender relations approach to achieving gender equality, to address gender adequately requires understanding the relational experience of women and men with the social, economic and political landscape; it requires a full understanding of how gender is defined within a given context.

\section{Gender Defined}

Gender, in the sense espoused by liberal feminism, relates to "the social construction of sexual difference," and/or the social construction that determines the expected code of conduct for masculinity and femininity (Scott 1998, and Jackson 1998). Codifying gender as a social construction shaping masculine and feminine identity and behavior is to recognize it as embodying a set of rules, which evolve through daily individual and group interaction with the institutions, persons, and physical space that constitute a given context. Feminist geographers Domosh and Seager (2001) present us with this concept in their exploration of gender in space and place. They express the relationship in three main themes: that space is gendered, that spatial organizations and relations help to shape human interactions, that gender influences human relationships to, and perceptions of built and natural environments. Gender is thus an experience of relational identity within a given social space, a form of social identity. 
The idea of social identity is one developed in the field of social psychology by Tajfel and Turner at the end of the 1970s to explain the experience of intergroup discrimination within societies (Turner and Reynolds 2010). The theory suggests that individuals with shared meaning within any given social space develop or assume a shared identity in relation to other groups. Gender identities are one such form of psychosocial grouping. Women and men thus determine their systems of being through their interactions and interdependence within and with their social contexts.

Within social psychology, understanding the components of social identity often parallel an assessment of a group's or individual's social power, that is, the level of control of that group or individual over its own fate, and that of others (Des Champs 1982, Gruenfeld and others 2008). In the dominant framing of gender dynamics within the international gender paradigm, the social identity of women would thus be seen as a dominated identity subordinated to male social identity, whereby men's position in society enables them to determine their social and economic fates independent of their relations to and with women, leading to a marginal view of women in most social structures. The assumed normalcy of dominant males versus subordinated females has come under scrutiny within many Caribbean societies.

\section{Challenging the Paradigm: The Caribbean Debate}

The exploration of male gender in development has not had much place in the international discourse on gender and development, but there have been vibrant discussions and debates within various regional and local contexts within and across academia, policy formulation and public opinion. Many of these discussions and debates have focused on realizing or refuting the reality of male crisis and/or marginalization. As 
with explorations of female gender and social and economic achievement, in discussions of male gender and achievement the emphasis has been placed on material power relations and access to resources. Much of the debate has been contextualized in the areas of employment and education. Various feminist scholars and scholars of masculinities have ascertained that the increased pace of globalization, especially in the decade of the 1990s, has led to shifts in the gender dimensions of labor force participation and employment. They note an increase of women in the labor force, and an increased number of women employed in jobs that have been traditionally the realm of males in society, or an increase in jobs held by women while jobs in male dominated industries decrease (Morton 1997, Connell 2000, Chant 2001, Abassi and Lutjens 2002). Giving particular attention to the United Kingdom, Linda McDowell (2003) tackled the issue of male crisis among young white males, showing their formerly sure economic futures being challenged by shifts in dominant economic sectors, and by manufacturing and other lower skilled jobs getting shipped overseas. She argued that these economic shifts and resulting uncertainties bring the concept of masculinity held by these young men in direct conflict with their lived realities. In the United States, Australia and United Kingdom, the late 1990s saw growing research and political attention to male educational attainment and the role of male social identity in effecting the perceived changes in male performance (Foster and others 2001). Others, such as Debbie Epstein (1998), sought to both explore and challenge the debate on male underachievement in education, and noted a need for more in-depth investigation into the issue.

The Anglophone Caribbean is also a context in which this debate has been fervent, and in which the intersection with international development discourse is 
evident. In fact, when discussion of possible male disadvantage $i s$ raised in the context of international development, it is this sub-region which is often referenced, especially with regard to gender in education (United States Agency for International Development 2005).

Caribbean feminists have given particular attention to context in assessing the situation of Caribbean women and highlighting their unique situation within the quest for gender equality. The liberal feminism at the core of the international gender paradigm has served as the pivotal paradigm within the Caribbean discourse; however, scholars and administrators alike ascertained that "Caribbean women just did not fit received images and rhetoric" (Barrow 1998: xi). They advocated the notion that to address gender in the region, history, culture and the international context needed to be factored into any analysis or political discussion. More specifically, they noted that any discussion on gender in the Caribbean would need to consider the effects of plantation slavery, postslavery colonization, and the nationalism spurred in the independence movement. They also noted that Caribbean gender analysis "cannot be divorced from development strategies and the web of inequalities in the world community" (Wiltshire-Brodber 1988).

Western liberal feminism also considered the effect of global development on women's social and economic standing. The movement posited that changes in the political economy of gender in the 1980s and 1990s resulted in two contradictory realities for women, one of the "traditional woman" - the stay at home care-giver - and the other of the "working woman." The interplay of the two realities was associated with "the breaking down of gender boundaries and of the challenges of new family roles for both women and men [emphasis added]" (Domosh and Seager 2001). In the Caribbean 
context, feminists challenged the assumed universality of this understanding of women's social and economic trajectory. Wiltshire-Brodber (1988) and other Caribbean feminists suggested that an understanding of gender relations in the Caribbean cannot begin from the premise of separate societal spheres - the public and private - with femininity being associated with home and domesticity. Caribbean feminists surmised that an understanding of gender relations in the Caribbean context needed to begin from an understanding that the exigencies of history had brought about a society in which gender was not a primary socioeconomic classification. Feminists in the Caribbean highlighted the leveling effects of the institution of slavery: The complete intermixing of African peoples, and the reality of the political economy of their existence, led to complex gender relations among slaves. While the industrial revolution brought shifting gender relations to Europe and North America, Caribbean women had long been in the "workplace" alongside men (Wiltshire-Brodber 1988, Momsen 1993).

For Caribbean feminists, the struggle was with colonialism, a struggle for better wages and racial equality, and the struggle was shared by both sexes. In the postemancipation era, colonial administrative practice, especially in the British territories, tended towards policies aimed at inculcating the value system and societal structures of the colonizer into the colonized community (Wiltshire-Brodber 1988). The dominant patriarchy of British society was thus superimposed on the pre-existing socio-cultural realities. Therefore, though independence blurred race/class lines, women were finding themselves increasingly subordinated and expected to exist in the domestic realm. It was this shift in the expectations of women's societal placement that helped spur a women's movement in the Caribbean that rallied behind the cause of women as a separate 
oppressed category (Antrobus 2004). The resulting strides of the Caribbean women's movement, and the interpretation of these strides by the rest of the world, placed Caribbean women in seemingly privileged positions as compared to their counterparts in other developing nations.

Despite their admired progress, Caribbean feminists continued to assert that the struggle for gender equality had not ended and suggested that, even in areas where women make up the majority they were concentrated at the base. There was continued declaration of blatant shortcomings in women's social and economic positioning. For example, feminist scholars continued to note that, even though women headed more than one-third of all Caribbean households, those in the workplace did not get equal pay for equal work and remained concentrated at the lower ends of income categories (Senior 1991, Abassi and Lutjens 2002, Ho 2002). Similar premises resonated in explorations of education, where feminists suggested that, even though girls and boys had equal access to education, girls were channeled into non-technical, non-scientific areas (WiltshireBrodber 1988).

However, just like their international counterparts, for the most part, Caribbean feminists had not fully considered the male gendered experience within their analyses. Males were present in the discourse only as the newly privileged gender, with male privilege being the main obstacle in the way of female social and economic development. As a result, by the mid-90s, while feminists continued to highlight women's material disadvantage, they were being bombarded from all angles with the argument that even though it is important to look at gender, too much attention was being paid to the development of females, at the expense of that of males. The argument that female 
oppression can be pinned to a power struggle of masculine over feminine, in which masculinity usually prevails, was being reversed and used against those who argued it to propose a situation of male crisis.

At the center of the argument for male crisis, was the work of Jamaican educator, Errol Miller. Miller's 1986 work, The Marginalization of the Black Male: Insights from the Development of the Teaching Profession (republished in 1994), and his 1991 publication, Men at Risk together fueled a decades-long discussion on the increasing educational underachievement of Caribbean boys, and an increasingly subsidiary placement of males (especially Afro-Caribbean males) within society. Miller's marginalization thesis suggested that the socialization patterns of the home and the school had shifted from favoring the achievement of boys, to that of girls. The term "male marginalization" became engrained in the popular vocabulary of the Caribbean (Mohammed 2004, Barriteau 2001), and the growing use of the term cemented the assertion that, in the labor market, the educational sectors, and even in private life, men were being displaced by women. Miller also used a concept of "place" in his assessment of the status of Caribbean boys and men. Miller reached his conclusion of male marginalization by applying what he called "the theory of place," which evaluated "the relative positions of individuals and groups with respect to power, resources, status, belief and culture" (Miller 1994).

The debate on male marginalization has been pervasive, and has played out across various social fields within the Caribbean. It has played out most visibly in Barbados and Jamaica, where it has shown itself within academia, within public opinion, and within policy discussion. By the mid-1990s talk of "male crisis" flooded these nations" 
newspapers. The Caribbean gender discourse had taken an unquestionable turn toward emphasis on male marginalization, and the complicity of women in fuelling the problem. Although feminist scholars have shown Caribbean women to be marginal in elected political leadership (Bolles 1998, Vassel 2003), shown the job market to be heavily gender segregated (De Alburquerque and Ruark 1998, Andaiye 2003), and shown Caribbean poverty as feminized (Ellis 2003) the debate continued. Examples of the tone of the debate can be found within newspaper headlines at the time: A 2000 article in the Jamaican Gleaner read "Female Dominance." Similarly, 2003 articles in Barbadian newspapers bore headlines such as, "Give Men Better Deal," "We Need to Treat Men Fair and Square," and "More Women Wearing the 'Pants' in Our Society." These articles mostly spoke to the impending doom of young, black males spurred by the exponential increase in educational achievement by girls, and by a feminized teaching profession, and the displacement of male workers by female workers. These phenomena are often attributed to a problem of paying too much attention to the plight of girls, while ignoring that of boys. For those who have advocated this position, the preference of women over men, and girls over boys, is seen as having transcended every societal sphere, so that women are replacing men as workers, managers, even as fathers, and this process is seen as placing men in a downward spiral of marginal socialization.

\section{Understanding the Gaps: The Need for Further Exploration}

While the international gender paradigm sees gender equality as synonymous with women's empowerment, challenges such as the concept of male marginalization put forth in the Caribbean provide reason to consider a revision to this approach. The challenge suggests that instruments and policies aimed at gender equality should avoid 
interpretations that assume a simple dichotomy of masculine and feminine that translates to a masculine-over-feminine understanding of power relations. In the exploratory work that follows the case of Barbados is presented as a means of understanding the overlaps and the gaps between the international gender paradigm, and the challenge put forth in the Caribbean context. 


\section{IMPLEMENTING THE GENDER PARADIGM: GENDER AND DEVELOPMENT IN BARBADOS}

The achievement of gender equality is lauded within international development discourse as a key factor in achieving social and economic development. It is seen as both a catalyst and outcome of just and sustainable social and economic policy (United Nations Development Programme 2010). As such, in assessing gender relations in any society, it is important to understand both the historical and current sociocultural and economic frameworks for development. The current chapter presents an overview of Barbados' development trajectory. It presents a picture of the economic environment over time, the social fabric upon which the economy has been sewn, and discusses the commitment of the state to human development in general, and to gender development and gender equality in particular.

As a Caribbean nation, Barbados sits among a region of nations highly affected by international opinion and discourse because of involvement with networks of international aid agencies, coupled with its political positioning at the international level (Mullings 1998, Maingot 2005). Like many of its regional counterparts, not only is Barbados affected by global economic and social processes, it is a creation thereof - a settlement whose demographic, social and economic composition has its origins in African slavery by European mercantilists, and plantation economy. Over the centuries, the Caribbean region has continued to be affected by the international division of labor, through the growth of export processing zones, its long-time dependence on large scale commodity exports, and its circulatory migration patterns. As such, analyzing gender 
relations in the Barbadian case will inevitably reveal the role of international political and academic opinion, as well as the role of international political economy (Mullings 1998, Wiley 1998, Benetti 2003, Pantin 2003). Within such a context, the intersection between global and local frameworks is inevitable in shaping the gender identities and the relations thereof.

\section{A Brief Economic Profile}

Barbados is a Small Island Developing State in the southeast of the Caribbean Basin. Compared to its regional counterparts and other developing states, Barbados has had a calm political and economic history (ECLAC-Caribbean 2001). At independence, Barbados had a low-income economy dependent on sugar production, but has since transformed to a high-income economy built on tourism and off-shore financial services. With these as the backbone of the Barbadian economy, supplemented by exports of sugar and its by-products, Barbados has continued to find itself well caught in the tide of the global market, susceptible to the ebbs and flows of global trends. Evidence of this is seen in the 2001 contraction of the economy, attributed to decline in tourist arrivals subsequent to the 11 September 2001 attack on New York City, general global economic downturn, and the impact of the Euro on sugar exports (United States Department of State 2010). Similarly, according to the Central Bank of Barbados, the global economic crisis, which took hold in 2008, is estimated to have cost Barbados almost 10 percentage points in economic growth over 2008 and 2009, mainly attributable to declines in long-stay visitors and a 3.9 percent decline in cruise ship passenger arrivals over the two years (Central Bank of Barbados 2010). Furthermore, World Bank estimates placed foreign direct investment at USD 36 million for 2007(The World Bank Group 2009). 


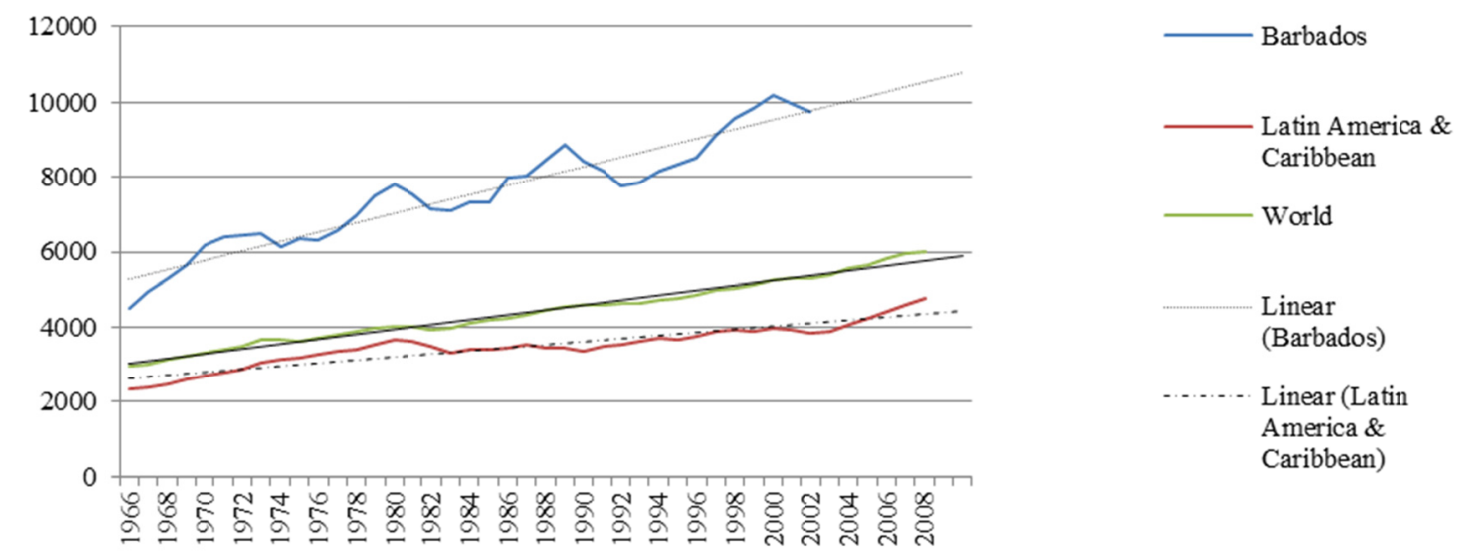

Figure 1: GDP Per Capita (Constant 2000 \$US)

Source: (The World Bank Group 2009)

Although a small state with an open economy, Barbados is one of the most economically successful countries in the Western Hemisphere, outside of the United States and Canada. While per capita GDP for the Latin America \& Caribbean region has remained consistently below the world average that of Barbados has stayed well above (see Figure 1). According to IMF estimates, the GDP for island-nation stood at USD 4.11 billion (in current prices) in 2010. In the same year, the GDP per capita (in current prices) was estimated to be USD 14,858.082 (International Monetary Fund 2011). The greatest contributor to GDP is services, which is not surprising noting afore mentioned makeup of the economy. Services contribute more than three-quarters of the country's GDP, while industry and agriculture contribute 20 and 4 percent respectively (The World Bank Group 2009).

\section{A Brief Demographic Profile}

Barbados is a fairly densely populated island, with approximately 285,000 people occupying 430 square kilometers of land (166 square miles). Females make up about fifty-two percent of the general population. When further broken down into adults 
(individuals aged fifteen and over), children, and other age categories, females remain a slight majority in all categories except children. Children account for 19percent of the total population, with the male population being slightly higher. Working-age adults (individuals aged fifteen to sixty-four) account for 71percent of the population with sex ratio being quite similar to the general population, with women accounting for 51percent. Within the elderly population, the difference in male and females is more marked, with females accounting for 61percent of this segment of the population (United States Central Intelligence Agency 2010). The population composition is quite understandable with the most recent estimates of life expectancy showing that of males at seventy-four years, and that of females at eighty (United Nations Statistics Division 2010). The ethnic makeup is 93percent of African descent, 3percent Anglo-European, 1percent of East Indian descent, 3percentself-classified as mixed, and3percent Chinese, Arab and Other classifications.

\section{Human Development}

In terms of other social indicators, Barbados boasts a 99.7 percent literacy rate, with about 0.3 percent adult illiteracy among both males and females in 2007. The infant mortality rate stands at 10.1 deaths/1000 live births (United Nations Statistics Division 2010). In terms of infrastructure and technology, about 150,000 fixed lines exist on the island, while there are 406,000 cellular phones in use (United States Central Intelligence Agency 2010). To get a feel for its overall development state, UNDP Human Development Reports could be considered. The human development approach employed by UNDP brings together the concepts of social progress, growth with equity, participation and freedom, sustainability and human security into a single development measure, the HDI. The HDI assigns a value between 0 and 1 (with 1 being the highest) 
that combines measures of health, educational attainment and living standard. As such, charting Barbados's progress in human development presents a holistic, people-centered picture of its development progress. The Human Development Index is the primary measure used in this approach. Prior to 2010, the index used life expectancy, adult literacy, and combined gross enrollment at the primary secondary and tertiary levels, and GDP per capita PPP in US dollars, as its primary indicators. For the 2010 iteration, the indicators were revised. Life expectancy at birth still constitutes the health indicator, while the indicators for education are now mean years of schooling and expected years of schooling, while Gross National Income (GNI) per capita PPP in US dollars now indicates living standard.

The Human Development Report 2010 ranked Barbados forty-second in the world, with a Human Development Index (HDI) of 0.788. With this latest ranking, Barbados retained its premier position within the Latin America and the Caribbean region and joined the ranks of developed non-OECD countries, such as Liechtenstein, Hong Kong (SAR) and Singapore. Within the measure, it holds a life expectancy at birth index of 0.913 , an education index of 0.712 , and an income index of 0.753 (United Nations Development Programme 2010). Overtime, Barbados has shown consistent improvement in the overall measure of human development (see Figure 2). As illustrated in Figure 2, although at a level of human development above its Anglophone Caribbean neighbors Barbados has maintained a very similar trajectory. 


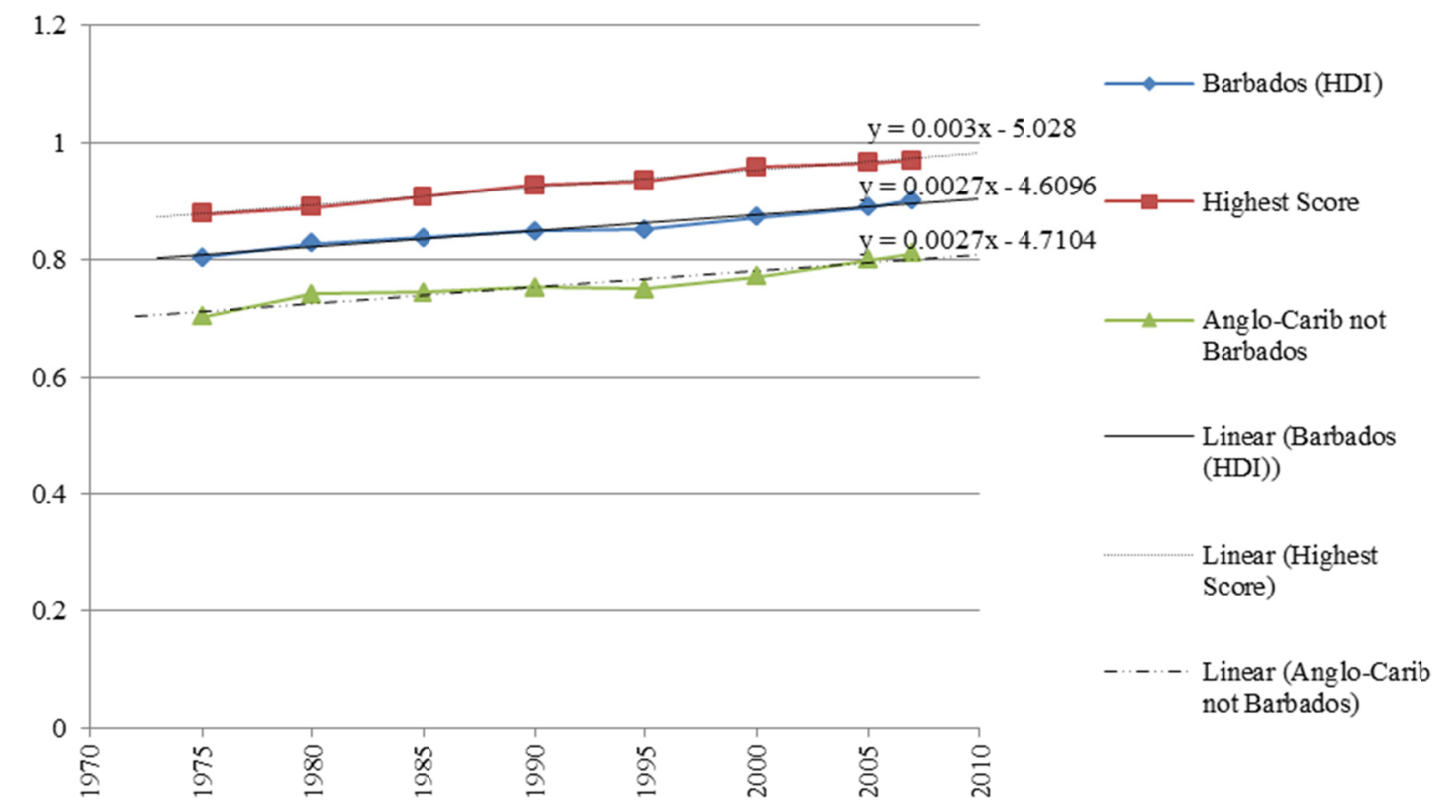

Figure 2: Barbados Trends in Human Development (Measured as HDI) ${ }^{5}$ Source: (United Nations Development Programme 2005, United Nations Development Programme 2009)

\section{Gender and Development}

As outlined in Chapter I, prior to 2010, the GDI and GEM were used to assess the gender dimensions of development and the level of women's empowerment within countries. Of the 155 countries for which HDI and GDI were reported in the Human Development Report (HDR) 2009, only 20 had a better GDI to HDI ratio than Barbados. Barbados showed a GDI of 0.900 and a GDI to HDI ratio of $99.7 \%$ (United Nations Development Programme 2009). In 2009, the GEM reported women in Barbados as holding 14 percent of parliamentary seats and holding 28 percent of all ministerial

\footnotetext{
${ }^{5} 1975$ Anglo-Carib not Barbados references Guyana, Jamaica and Trinidad \& Tobago. Although only three territories, in terms of assigned ranks, these three represent the full range of Anglo Caribbean placement in the given year. 1980-1995 include The Bahamas, Guyana, Jamaica and Trinidad \& Tobago. 2000 and 2007 include data for all independent Anglophone territories (Antigua \& Barbuda, The Bahamas, Dominica, Grenada, Guyana, Jamaica, St. Kitts \& Nevis, St. Lucia, St. Vincent \& the Grenadines and Trinidad \& Tobago. 2005 excludes Antigua and Barbuda. HDI for 2010 is not included in the timeline above because of the radical shift in the nature of the indicators in the Education Index.
} 
positions. Barbadian women comprised 43 percent of all legislators, senior officials and managers and average 52 percent of the female professional and technical workers while earning about 65 percent of what their male counterparts earned. In the 2009 HDR, Barbados showed a GEM of 0.632 , ranking it thirty-seventh in the world, and second to Trinidad \& Tobago (ranked fourteenth with a GEM of 0.801) within the Anglophone Caribbean. ${ }^{6}$

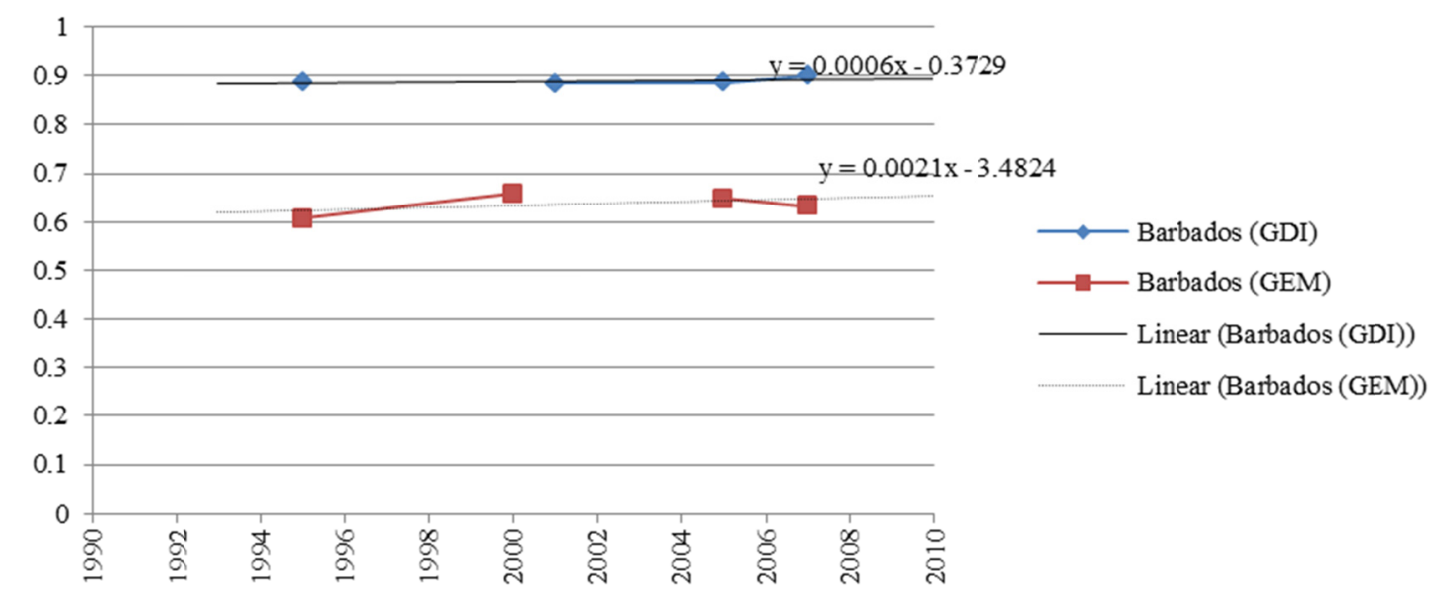

Figure 3: Barbados Trends in Gendered Human Development and Women's Empowerment (Measured as GDI and GEM)

Source: (United Nations Development Programme 2005, United Nations Development Programme 2009)

\footnotetext{
${ }^{6}$ Barbados GEM value reported in the HDR 2009 ranked it fourth in Latin America \& the Caribbean behind Trinidad and Tobago, Cuba and Peru respectively.
} 




Figure 4: Barbados Trends in Gendered Human Development (Measured as GDI) ${ }^{7}$ Source: (United Nations Development Programme 2005, United Nations Development Programme 2009)

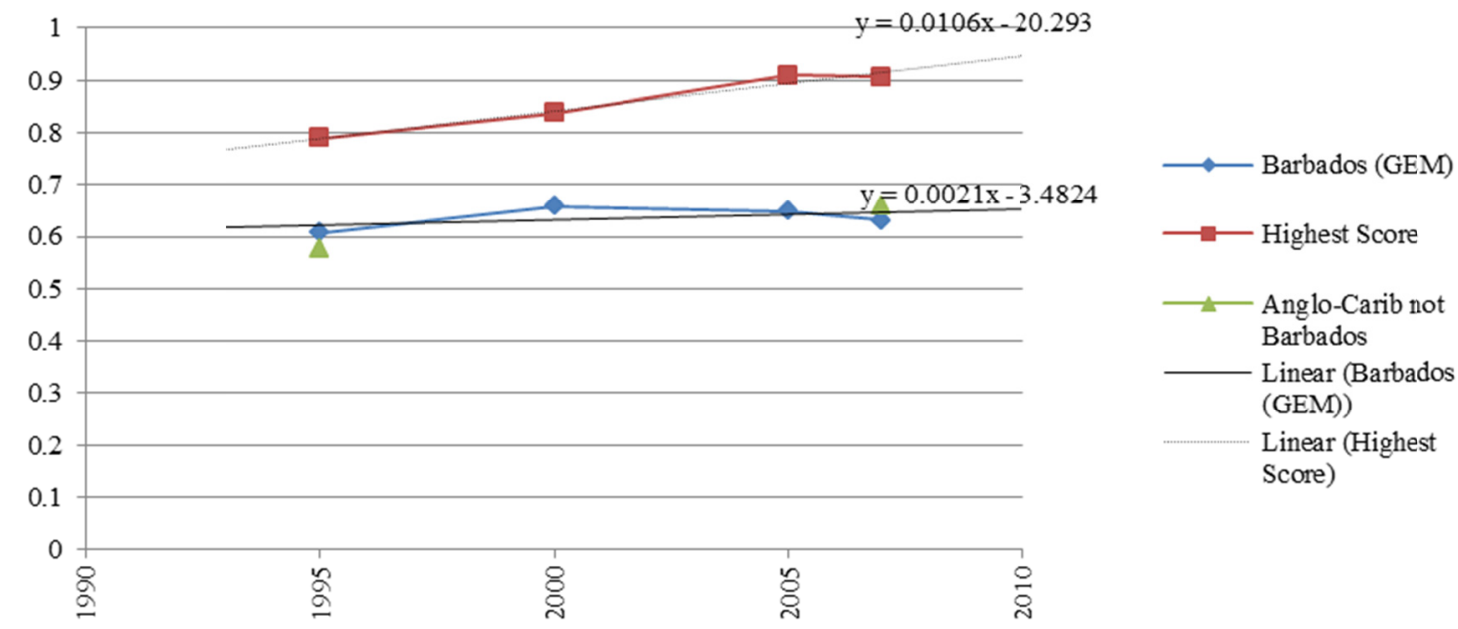

Figure 5: Barbados Trends in Women's Empowerment (Measured as GEM) ${ }^{8}$ Source: (United Nations Development Programme 2005, United Nations Development Programme 2009)

\footnotetext{
${ }^{7}$ The year 2001 was used as the data point in this instance, as this closest available data to the year 2000 data point used in the other comparison charts. 1997 provides the next most recent data. 1995 AngloCaribbean not Barbados includes data for Bahamas, Guyana, Jamaica and Trinidad \& Tobago, while 2007 references Guyana, Jamaica and Trinidad \& Tobago.

${ }^{8} 1995$ Anglo-Caribbean not Barbados includes data for Bahamas, Guyana, Jamaica and Trinidad \& Tobago, while 2007 references Guyana, Jamaica and Trinidad \& Tobago.
} 
In Barbados, the GDI and GEM have followed differing trends in progression (see Figures 3, 4 and 5). The GDI decreased from 1995 to 2001 and then followed an increasing trend, drawing closer to the top ranked performance over time. The GEM, on the other hand, increased from 1995 to 2000 reducing from 2000 to 2007, growing farther away from the top ranked performance. What this indicates, is that while women and men are benefiting more and more equally from the basic provisions of human development, women's combined share in top-level legislative and professional positions has declined from 2000 to 2007. In both cases, the rate of progress has been generally slower than the highest ranking countries in the world. On the basis of these measures, Barbados finds itself above average, within the Anglophone Caribbean, with regard to equal development, but in a more medial position with regard to women's empowerment. ${ }^{9}$

Figures 6, 7, 8 and 9 illustrate the trends in the basic human development components of the Gender Development Index. In Barbados male and female life expectancy are on par with global norms, with females living about five years longer than males. In the area of income distribution, as is the global norm, from the mid-1990s through 2007 in Barbados men have maintained a higher average income. On the other hand, male and female literacy have remained on par from the beginning of the 2000s and since the mid-1990s the rate of male educational enrollment has been below that of females and progressed at a slower pace. Chapter IV will examine these phenomena in greater detail and explore the performance of Barbados 2010 launched Gender Inequality Index, which combines the concepts of gender disparity and empowerment.

\footnotetext{
${ }^{9}$ Very few Anglophone Caribbean territories have composite GDI and GEM values for the period under review. This comparison was made on the basis of the composite values for Bahamas, Guyana, Jamaica and Trinidad \& Tobago for 1995 and 2007, and by comparison of individual components for additional territories, where available, throughout the year range.
} 


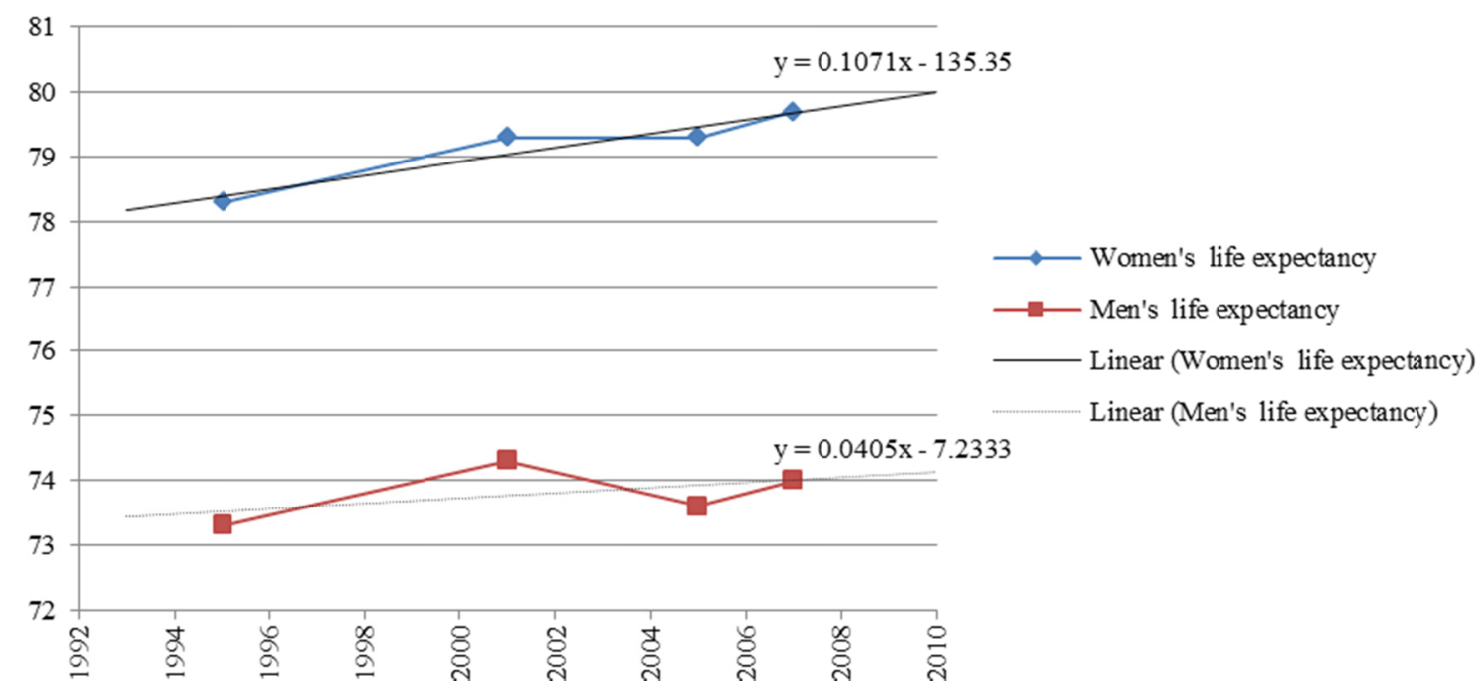

Figure 6: Barbados Trends in Male and Female Life Expectancy, 1995-2007 Source: (United Nations Development Programme 1997, United Nations Development Programme 2002, United Nations Development Programme 2007, United Nations Development Programme 2009)

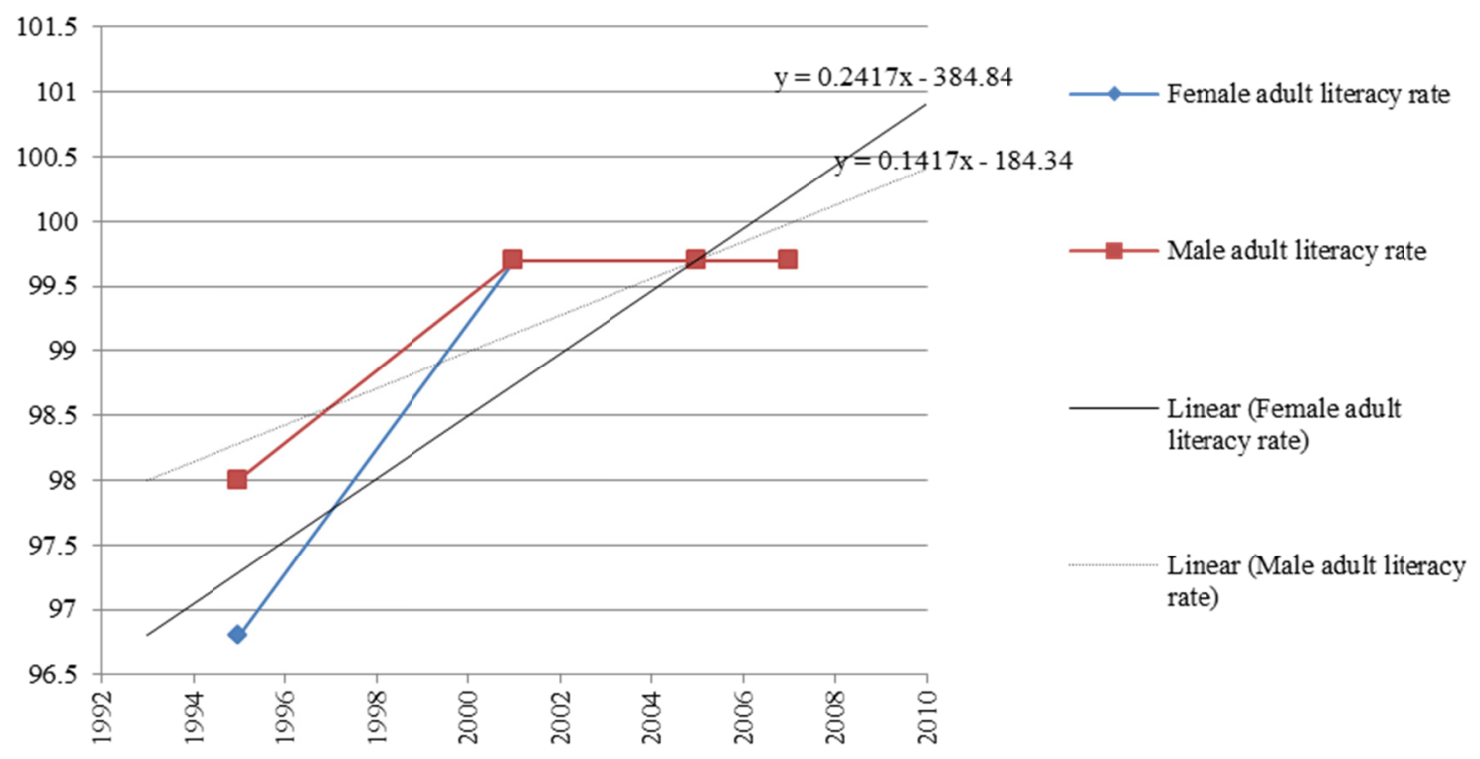

Figure 7: Barbados Trends in Male and Female Literacy Rates, 1995-2007 ${ }^{10}$ Source: (United Nations Development Programme 1997, United Nations Development Programme 2002, United Nations Development Programme 2007, United Nations Development Programme 2009)

\footnotetext{
${ }^{10}$ The male and female literacy rates converge in the year 2000 and remain equal throughout the remainder of the period represented.
} 


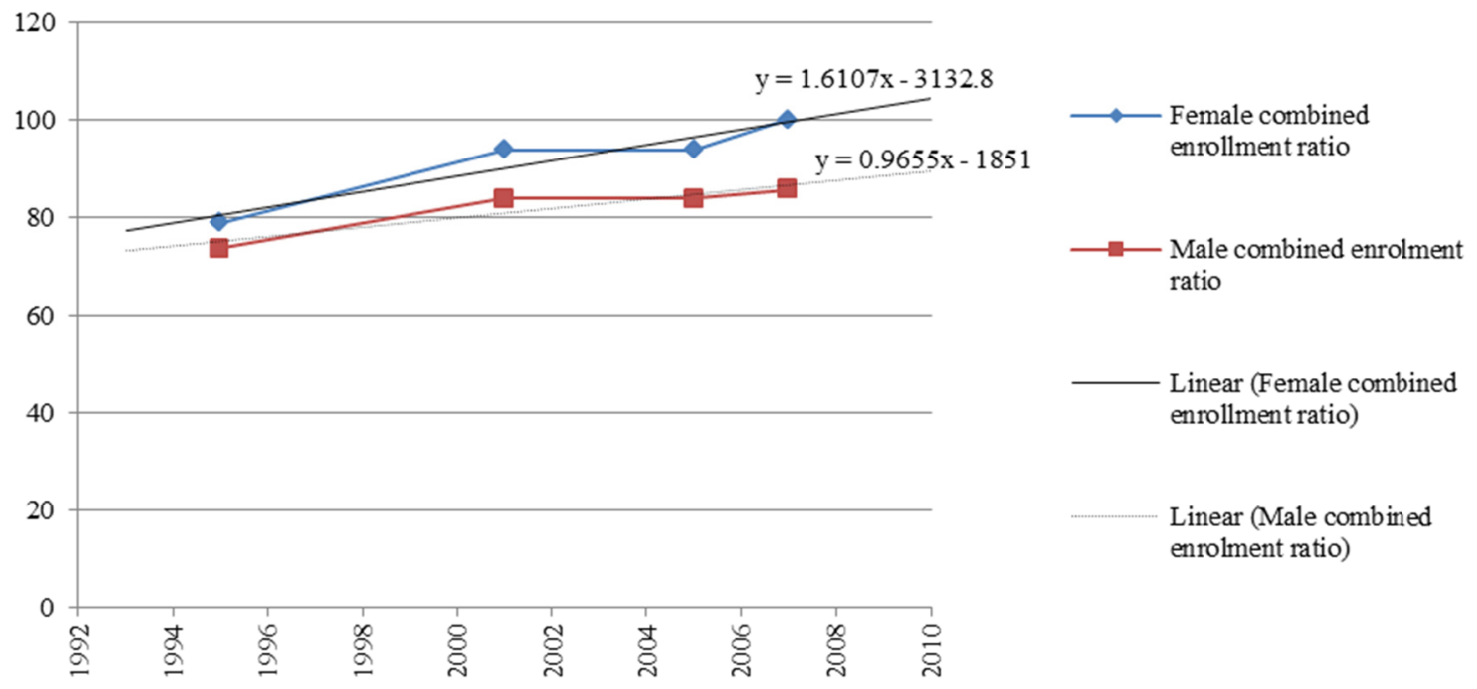

Figure 8: Barbados Trends in Male and Female Combined Enrollment Ratios, 19952007

Source: (United Nations Development Programme 1997, United Nations Development Programme 2002, United Nations Development Programme 2007, United Nations Development Programme 2009)

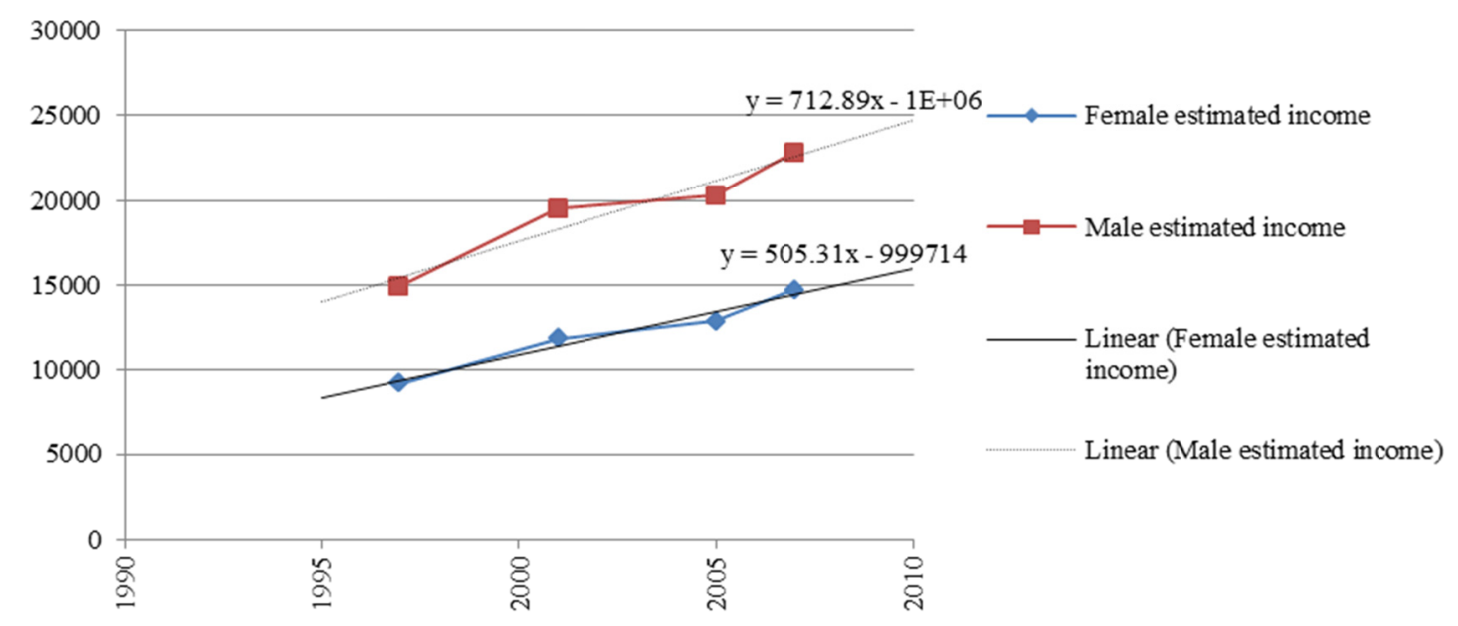

Figure 9: Male and Female Estimated Earned Income, 1997-2007 ${ }^{11}$

Source: (United Nations Development Programme 1997, United Nations Development Programme 2002, United Nations Development Programme 2007, United Nations Development Programme 2009)

\footnotetext{
${ }^{11} 1997$ is used as this is the closest year to the 1995 data point, used in the previous information charts, with an estimate of earned income.
} 


\section{International Commitments and Domestic Action}

As a member of the United Nations, Barbados has aligned itself with an

institution and system of governance committed to "the dignity and worth of the human person ... [and] the equal rights of men and women" (United Nations 2006, 3). This commitment coalesces with the constitutional entitlement of "...every person in Barbados ...to the fundamental rights and freedoms of the individual...whatever his race, place of origin, political opinions, colour, creed or sex" (Constitution of Barbados). Within this body, Barbados is signatory to numerous treaties and other forms of agreement, which signal a commitment to gender equality, and to women's empowerment in particular. The tables that follow present a synopsis of the gender focused agreements to which Barbados is a party:

\begin{tabular}{|c|c|c|c|}
\hline \multicolumn{4}{|c|}{ UN Treaties and Agreements Addressing Gender to which Barbados is a Party } \\
\hline Agreement & $\begin{array}{l}\text { Year } \\
\text { Authored }\end{array}$ & $\begin{array}{l}\text { Year } \\
\text { signed/acceded/ratified }\end{array}$ & Provision \\
\hline $\begin{array}{l}\text { International } \\
\text { Covenant on } \\
\text { Economic, Social } \\
\text { and Cultural Rights, }\end{array}$ & 1966 & $-/-/ 1973$ & $\begin{array}{l}\text { Seeks to ensure the equal } \\
\text { right of men and women } \\
\text { to enjoyment of economic, } \\
\text { social and cultural rights, } \\
\text { and makes specific } \\
\text { provision for fair wages } \\
\text { and equal pay for equal } \\
\text { work }\end{array}$ \\
\hline $\begin{array}{l}\text { The International } \\
\text { Covenant on Civil } \\
\text { and Political Rights } \\
\text { (and its Optional } \\
\text { Protocol) }\end{array}$ & 1966 & $-/-/ 1973$ & $\begin{array}{l}\text { Seeks to ensure the equal } \\
\text { right of men and women } \\
\text { to enjoyment of civil and } \\
\text { political rights; renounces } \\
\text { the death penalty for } \\
\text { pregnant women; } \\
\text { addresses the right of men } \\
\text { and women to marry }\end{array}$ \\
\hline
\end{tabular}


Convention on the $\quad 1953 \quad-/-/ 1973$
Political Rights of
Women

$\begin{array}{lcc}\begin{array}{l}\text { Equal Remuneration } \\ \text { Convention }\end{array} & 1951 & -/-/ 1974 \\ \begin{array}{l}\text { Discrimination } \\ \text { (Employment and }\end{array} & 1958 & -/-/ 1974 \\ \begin{array}{l}\text { Occupation) } \\ \text { Convention }\end{array} & & \\ \end{array}$

Employment Policy $1964 \quad-/-/ 1976$
Convention

Convention on the

Nationality of Married

Women

1979

$-/-/ 1979$

1980/-/1980

Convention on the

Elimination of All

Forms of

Discrimination Against

Women
Seeks to equalize the status of men and women in the enjoyment and exercise of political rights, in accordance with the provisions of the Charter of the United Nations and of the Universal

Declaration of Human Rights. Seeks to ensure equal pay for equal work

Seeks to eliminate "any

distinction, exclusion or preference made on the basis of race, colour, sex, religion, political opinion, national extraction or social origin, which has the effect of nullifying or impairing equality of opportunity or treatment in employment or occupation" Promotes the creation of full, productive and freely chosen employment, and requires "freedom of choice of employment and the fullest possible opportunity for each worker to qualify for, and to use his skills and endowments in, a job for which he is well suited, irrespective of race, colour, sex, religion, political opinion, national extraction or social origin."

Seeks to protect the rights of women to maintain or change an assumed nationality regardless of shifts in marital status.

Defines the concept of discrimination against women and structures an agenda for national action to end it 
$\begin{array}{ll}\text { Protocol to Prevent, } 2001 \quad 2001 /-/- & \begin{array}{l}\text { Paying particular attention to } \\ \text { women and children, seeks to } \\ \text { Suppress and Punish } \\ \text { Trafficking in Persons, }\end{array} \\ \begin{array}{l}\text { Especially Women and } \\ \text { Children, }\end{array} & \text { instances of trafficking } \\ \text { Supplementing the } & \\ \text { United Nations } & \\ \text { Convention Against } & \\ \text { Transnational } & \\ \text { Organized Crime. } & \end{array}$

\begin{tabular}{|c|c|c|}
\hline UN Declarations and Agreeı & nents Ad & essing Gender to which Barbados Subscribes \\
\hline Agreement & $\begin{array}{l}\text { Year } \\
\text { Adopted }\end{array}$ & Provision \\
\hline $\begin{array}{l}\text { Copenhagen Declaration } \\
\text { on Social Development, } \\
\text { and the Programme of } \\
\text { Action of the World } \\
\text { Summit for Social } \\
\text { Development }\end{array}$ & 1995 & $\begin{array}{l}\text { Recognizes women as especially vulnerable to } \\
\text { deprivation, and includes a commitment to } \\
\text { promoting equality and equity between women } \\
\text { and men and enhancing women's participation } \\
\text { in political, civil, economic, social and cultural } \\
\text { life and in development. }\end{array}$ \\
\hline $\begin{array}{l}\text { Beijing Declaration and } \\
\text { Platform of Action }\end{array}$ & 1995 & $\begin{array}{l}\text { Focuses on key issues determined as obstacles } \\
\text { to the advancement of women. It identified } \\
12 \text { critical areas of concern. }\end{array}$ \\
\hline $\begin{array}{l}\text { World Programme of } \\
\text { Action for Youth }\end{array}$ & 1995 & $\begin{array}{l}\text { Seeks to improve the situation of young people } \\
\text { all over the world, and includes as one of its } \\
\text { priority areas, a focus on improving the } \\
\text { situation of girls and young women }\end{array}$ \\
\hline $\begin{array}{l}\text { United Nations Millennium } \\
\text { Declaration }\end{array}$ & 2000 & $\begin{array}{l}\text { Seeks to reduce extreme poverty and improve } \\
\text { overall human development through the } \\
\text { achievement of various time-bound targets. It } \\
\text { holds as its third goal the promotion of gender } \\
\text { equality and the empowerment of women. }\end{array}$ \\
\hline
\end{tabular}

Barbados has also affirmed its political commitment to women's empowerment and the promotion of women's rights, in its traditional co-sponsorship of various resolutions within the bodies of the United Nations; particularly within the third committee of the General Assembly under the Agenda Item "Advancement of Women." In this context, Barbados has been a traditional co-sponsor of the resolution "Supporting 
efforts to end obstetric fistula," a resolution recognizing the connections between poverty, malnutrition, lack of or inadequate or inaccessible health services, early childbearing, early marriage of the girl child and gender discrimination as core causes of obstetric fistula, and stresses the need to address the social issues that contribute to the problem. Barbados has also cosponsored traditional resolutions on CEDAW, asking states to comply with reporting provisions and to limit the reservations with which they subscribe to the instrument; and been traditional co-sponsors on resolutions addressing the situation of older women in society, the integration of older women into development, the girl child, and promotion of the work and development of the United Nations Development Fund for Women. In addition, the country has been quite visible in deliberations and resolutions regarding the elimination of violence against women and, in fact, in 1999 cosponsored the resolution to proclaim an international day on the issue.

Within the global political arena, not only has Barbados "verbalized" its political alignment with the policies framing the international gender paradigm, but it has made efforts to portray compliance with the edicts of these policies through the review and modification of various domestic laws and the creation of applicable practices, programs and policies. Using the reports of Barbados to various gender focused bodies of the United Nations and the recorded discussions of these reports, this discussion seeks to highlight the nexus between the domestic gender and development context and the international gender paradigm. In so doing the section presents a picture not only of the state-level focus with regard to gender equality and its related programming, but the relationship of this focus to the international discourse. 
Barbados was an early signatory to CEDAW, the central international instrument framing expectation for state-level action on gender equality and women's empowerment. As a party to the Convention, Barbados is required to submit periodic reports that address its maintenance of or progress toward the provisions of the Convention. On the basis of the reports from the first, second, third and fourth periodic reports of Barbados to CEDAW and the discussion and examination thereof, Barbados has made numerous alterations to domestic law and policies in compliance with the treaty. These changes and modifications can be seen as falling into five main categories: social status, protection under the law, education, employment and wages, and civic and political participation. In addition, of the twelve critical areas of concern of the Beijing Platform of Action, Barbados adopted five as priority areas, specifically those addressing mechanisms for the promotion of women's advancement, the burden of poverty on women, equal access to welfare and related services, violence against women, and women and decision-making (Committee on the Elimination of Discrimintation against Women 2003).

\section{Social Status and Gender Policy in Barbados}

Concern for women and women's development is an area of focus well established in Barbadian political life. A Ministry of Women's Affairs had formed part of the Barbadian legislature as early as 1970. In 1976, the Government of Barbados established the National Commission on the Status of Women (NCSW). The establishment of the NCSW came on the tail of the International Women's Year (1975), the First World Conference on Women held in Mexico City 19 June-2 July 1975 and the launch of the United Nations Decade for Women (1976-1985). The National Commission 
conducted an analysis on the status of women in Barbados, and prepared 212

recommendations to the Government on eliminating discrimination against women. From the submission of the report (1978) through the initial report of Barbados to CEDAW, which covered the period 1982-1987, 190 of these recommendations had been implemented (Committee on the Elimination of Discrimination against Women 1993).

The NCSW later became the National Advisory Council on Women, and was again renamed as the National Advisory Council on Gender (NACG) and re-constituted in June 2001with the mandate to identify, monitor, and make recommendations to the Minister with responsibility for gender affairs on relevant issues. More specifically, the NACG was set up with the modified mandate of monitoring progress in implementation of international instruments such as CEDAW and the Beijing Platform of Action, and advising the Minister on matters affecting the interests of women and men with respect to human development and group rights. The Council is responsible for investigating and advising on issues of systemic gender-based discrimination, and for promoting gender equity and mainstreaming in policy-making and programming. The NACG was also assigned to work with Government to formulate a National Policy on Gender and a National Plan of Action on Gender Affairs (Barbados Bureau of Gender Affairs 2004).

The Bureau of Women's Affairs was also established by the Government in 1976 as an administrative unit within the Ministry of Legal Affairs, to function as the secretariat of the NCSW, and continued in its secretariat role to the NACG. The Bureau acts as the bridge between the council and the decision-making bodies of Government. As such, the Bureau's initial responsibilities included monitoring the general situation of women, keeping track of the recommendations of the NCSW and ensuring their 
implementation, making recommendation on matters affecting women, raising societal awareness on the role of women, and promoting research on the problems and needs of women.

As with its Advisory Council, in line with the international paradigm shift from women in development to gender in development, and the resulting recommendations of the Beijing Plan of Action, in 2000, the Bureau was renamed the Bureau of Gender Affairs, and was handed a slightly modified mandate. The concept of the gendered male was added to its mandate such that the theoretical aim was now to address inclusively any gender discrimination or gender-based hindrances. Now located in the Ministry of Family, Culture, Sport and Youth, the Bureau has maintained its role as secretariat, and prepares reports on gender affairs to the domestic legislature, as well as the reports of the government to the international bodies that monitor states progress in fulfilling their commitments to gender-focused international instruments. However, despite its recent strengthening, with just three program officers, the Bureau is a small division with a big mandate. The Government of Barbados, in consecutive reports to CEDAW, has noted that the Bureau has limited facilities and insufficient staff, but noted that the government is examining ways to improve the Bureau's functioning. This fault was reiterated by the National Organization of Women in their contribution to the Fourth Periodic Report of Barbados (for the period 1994-1999) to CEDAW (Committee on the Elimination of Discrimination against Women 2000). Its budgetary allocation for 2008-2009 was a mere BBD 756,602 (ECLAC-Caribbean 2010, 4). Nevertheless, the significant role tasked to the Bureau in informing the country's legislature provides some testimony to a place for women's/gender issues in government decision-making. 
Despite the display of some level of commitment by the Barbadian state to eliminating discrimination against women, the fullness of the legal status of women and their rights in Barbados has been often questioned at the international level because of the way gender is addressed in the country's constitution. Although the Constitution of Barbados provides for the "fundamental rights and freedoms of the individual" regardless of sex, it does not make particular reference to sex in its clause on non-discrimination. This was acknowledged by the government as a shortcoming in the Fourth Periodic Report of Barbados to the Committee on the Elimination of Discrimination against Women. In 1997, the Barbados Constitution Review Commission recommended that the clause on discrimination in the Constitution be altered to make exclusive mention of sex discrimination; the government of Barbados is thus considering revision of its constitutional clause on non-discrimination (Committee on the Elimination of Discrimination against Women 2000).

In its reports at the international level, the government of Barbados admits that the issue of citizenship has been one where legal discrimination has served to subject women to a lower social status than that of men. Until the early nineties, the nationality laws of Barbados discriminated against women in a way that suggested that their nationality/citizenship was less than that of their male counterparts. The child of a Barbadian woman, born overseas, whose father was a non-national was not considered a citizen by descent, while that of a Barbadian male with a non-national mother was afforded citizenship. Barbados claims to have addressed this issue in the Constitution (Amendment) Act of 2000 (Committee on the Elimination of Discrimintation against Women 2003); however, some level of discrimination against women still exists as the 
wording of the law suggests that a male citizen by descent, or any other means, can pass citizenship, while only women born in Barbados can pass citizenship to children born overseas. $^{12}$

Another important factor raised by Barbados in discussing gender and gender dynamics in the country is the question of household headship. The level of female household headship is quite high, as is the case with most Caribbean nations. Throughout the Caribbean female household headship stands between 30 and 50 percent, and many of these females have sole financial responsibility (ECLAC-Caribbean 2010). On the basis of available census data, more than 44 percent of households in Barbados are headed by women (Committee on the Elimination of Discrimination against Women 2002). In consideration of consecutive reports of Barbados to CEDAW committee members enquired into the reasons behind the high percentage of female headed households and the professions of these household heads. The single-female-head household is recognized by the government as a legacy of slavery, which discouraged permanent family unions and marriage. The government recognizes the norm of the female headed household as having been made possible through the extended family as a support mechanism. As such, in its responses to CEDAW, the government did not present this phenomenon as a situation of disadvantage. In its responses, the government emphasized that though these households account for 53.6 percent of households living in poverty, on the other hand around 60 percent of all mortgages were granted to women (Committee on

\footnotetext{
${ }^{12}$ See The Constitution of Barbados L.R.O 2000 Section 5(1) \& (2). Available at http://www.lexadin.nl/wlg/legis/nofr/oeur/lxwebar.htm accessed 17 October 2010.
} 
the Elimination of Discrimination against Women 1992b, Committee on the Elimination of Discrimination against Women 1992c).

Barbados sees its educational system as a major tool by which to address/modify the social status of women. In its 1988-89 CEDAW report, the Government of Barbados cited co-education and the inclusion of family life education in school curricula as effecting attitudinal change towards the roles of males and females in society. They noted that co-education encouraged both boys and girls to pursue similar fields of study, which led to more balance labor-market competition and more men and women working together. Barbados suggested that co-education and its effects on the labor market were leading to more economic equality within households and increasing the instance of shared child rearing and home care. However, the government also suggested that show of male dominance through violence continued to be a real problem. In direct response to the perceived problem of continued violence against women, the government's Bureau of Gender Affairs partnered with the National Organization of Women from 2002, in a program of gender sensitization in secondary schools. The program was run in November to focus attention on the International Day for the Elimination of Violence against Women, which falls on 25 November each year. The gender sensitization program held the main objective of raising awareness of the importance and implications of gender, a step deemed necessary to foster a society that "accepts gender equality as a national goal" (Barbados Bureau of Gender Affairs 2004).

In forwarding the concept of "gender equality as a national goal," Barbados included a program on women, in its 1988-89 Development Plan, in an effort to mainstream women's issues across the ministerial portfolios. The Government of 
Barbados attributed this move to recommendation from the 1987 WAMM and noted the alignment of this decision with the 1976 recommendations of the National Commission on the Status of Women (Committee on the Elimination of Discrimination against Women 1992a). The 1988-89 program on women included measures to increase the participation of women in decision-making, including annual leadership training targeting women. The program also recommended activities to promote women's employment and income-generating enterprises.

More recently, in July 2008, CARICOM, of which Barbados is a member, established the Caribbean Institute for Women in Leadership aimed at increasing the number of women in politics and decision-making. The institute is located in Barbados.

\section{Protection under the Law}

In its reports to international bodies, Barbados references its Family Law Act as having raised the status of women and their children within Barbadian society. Within the provisions of the Act, partners of common-law relationships are granted spousal recognition to the extent that the right to maintenance and property distribution is enforceable upon separation. The law also subverted the concept of illegitimacy, as children born out of wedlock are considered the children of both parents and have the same rights as children born within a marital union.

In 1988 , in an effort to rectify noted shortcomings in national law in protection of women against violence and abuse, the Barbados legislature drafted two bills to replace the Offences against the Person Act of 1868. The Domestic Violence Bill was drafted in an effort to protect the victims of domestic and sexual violence, and to reverse perceived reluctance of law enforcement to address domestic violence. The Sexual Offences Bill 
was drafted to address a perceived increase of violence against women, and a raised concern by women on the provisions of the Offences against the Person Act with regard to evidence and due process (Committee on the Elimination of Discrimination against Women 1992a). These bills became law in 1992.

\section{Gender Policy and Education}

In addition to their commitment to CEDAW, as signatories to the Convention against Discrimination in Education, Barbados has committed itself to ensuring equal access to education for both sexes, a commitment noted repeatedly in reports to CEDAW. As such, by the end of the 1980s, co-education was the norm in Barbados. In its second and third periodic report to the Committee on the Elimination of Discrimination against Women, the Government highlighted its attention to education, noting that education has been free up to the post-secondary level since the 1960s, and, by the start of the 1990s was assigned the fourth highest budget allotment (Committee on the Elimination of Discrimination against Women 1992a). Interestingly, concerns for gender inequality in the area of education have been voiced mainly with regard to male underperformance:

"Even though there are no clear statistics on drop-out rates, it is apparent that girls perform better than boys in schools and in adult education institutions. Some educators have argued that co-education has increased the competitive nature within the schools between girls and boys. Moreover, it is argued that while this type of activity is encouraging, girls are given the competitive edge because they mature much faster than boys" (Committee on the Elimination of Discrimination against Women 1992).

With regard to female educational performance, the government did express concern that, although not prohibited by policy or performance, girls still tended to pursue traditionally female oriented courses such as teaching and nursing. 
The elimination of sex stereotyping in schools has also been a priority of the Government of Barbados. At the end of the 1980s, Barbados participated in a study on "Gender Stereotyping in Primary School Textbooks," being undertaken by the Commonwealth Secretariat. The aim of the study was to ensure that text books and pedagogy at the primary level was unbiased in the area of gender (Committee on the Elimination of Discrimination against Women 1992a). Interestingly, despite having expressed clear concern for the male experience in education, the reports of the government implied a focus on eliminating female stereotyping.

\section{Gender, Employment and Wages}

Even before its ratification of CEDAW, Barbados had shown its political commitment to the elimination of all forms of discrimination against women in employment, in its ratifications of ILO Convention No. 100: Equal Remuneration Convention, ILO Convention No. 111: Discrimination (Employment and Occupation) Convention and ILO Convention No. 122: Employment Policy Convention.

As earlier expressed, for the Government of Barbados, the educational system is an important factor in reducing sex-based discrimination and gender inequality in employment. Open and equal access to education of girls and boys is seen as promoting free choices of professions and job opportunities (Committee on the Elimination of Discrimination against Women 1992a). The government sees increased equality of access and choice within education, as promoting the gradual shift of men and women into professions not traditionally common for the given sex.

With regard to wage discrimination, as mentioned in the discussion on protection under the law, the Shop Act was passed, in 1996, in an effort to eliminate discrimination 
against women, and to raise their economic profile (Committee on the Elimination of Discrimination against Women 2000). The Act raised the minimum wage for shop assistants and similar service posts, a heavily female sector of the labor force.

Despite the political commitment and legislative changes the government still acknowledges that employment and wage inequalities remain, which need to be addressed. In reporting to CEDAW, the government noted that in $1999,6.56$ percent of men earned an average weekly age over BBD 800, while only 5.27 percent of women did. Similarly, while 55.72 percent of men earned a weekly wage less than BBD 400, 66.78 percent of women did (Committee on the Elimination of Discrimination against Women 2002). In addition, women have higher unemployment rates. Chapter IV, which discusses the socioeconomic relations of gender, will take a deeper look at employment and income.

\section{Gender Policy and Political Participation}

The championing of women's rights and empowerment is a task well supported by civil society in Barbados. In its initial report to the CEDAW, the Government of Barbados referenced the deep involvement of forty-four women's organizations in the implementation of the recommendations of the National Commission (Committee on the Elimination of Discrimination against Women 1993). The Government of Barbados provides subventions to women's organizations that promote the cause of women and further young women's careers. As of May 2008, the number of women's organizations receiving stipends stood at fourteen (Barbados 2008). The government gives continual recognition of the support of domestic-level civil-society organizations as well as of the important role played by international agencies and donors. For example, the statement of 
Barbados to the fifty-second meeting of the Commission on the Status of Women in 2008 not only commended local NGOs for their advocacy of women's issues, but highlighted the programming and financial assistance provided by the Inter-American Development Bank, the World Bank, UNIFEM and the Canadian International Development Agency (Barbados 2008).

Although the Government of Barbados had maintained a commitment to the advancement of women, they continued to report low political participation of women. Government reports have highlighted continued concentration of female appointments to decision-making positions within areas deemed traditionally suitable for females. By the end of 1988, the only public boards with a predominance of females or with near equality were the Child Care Board, the Government Industrial School, the Hillside Home Welfare Board ${ }^{13}$ and the General Nursing Council. The Barbadian government presented the disparity in male and female representation on public boards as a reflection of a societal held belief that women's expertise was confined to areas of caretaking and nurturing. By the end of 1989, Government had begun efforts to address the stereotype and the shortage of female board members by appointing equal numbers of men and women to the Film Censorship Board and the Paramedical Professions Council (Committee on the Elimination of Discrimination against Women 1992a).

In reports to CEDAW, Barbados also highlighted a paradox in women's political participation. In its fourth periodic report, the government noted that Barbadian women have had the right to vote and be elected to parliament since 1944, but voting was at first restricted to persons with an income of $£ 20$ sterling. They noted that with the introduction

\footnotetext{
${ }^{13}$ Manages the Hillside Home elder care facility
} 
of universal suffrage in 1951 women quickly became the majority in voter representation. It was in that same year, 1951, that the first female candidate was elected to the House of Assembly. In addition, women have long been the major players in political campaigns and other organizational work of the island's political parties. The government lamented that, despite this reality, women make up a small proportion of candidates in electoral campaigns. In the 2008 national election, eight females campaigned for election across the two parties and 30 constituencies, and of these, three were elected to office (ECLACCaribbean 2010). Again highlighting a seeming paradox, Barbados noted that though only a few women have held political office in Barbados, they occupy or have occupied some of the highest political posts including Governor General, Governor of the Central Bank, Leader of the Senate, Deputy Prime Minister, Leader of the Opposition and the Deputy Principal of the University of the West Indies Cave Hill Campus.

\section{Conclusion: The Barbadian State and the International Gender Paradigm}

The development trajectory outlined here shows Barbados to be a country long committed to social justice and the development of its human capital. Nevertheless, with a social and legislative structure modeled from a patriarchal imperial system, scrutiny of its legislative and programming structure since its independence, from the perspective of women's rights and social status, did show the need to modify some laws and institute some policies to level the playing field of gender. Whether or not these modifications were domestically or internationally driven is not here debated, but what is certain is that these moves at the national level coincided with the international push toward gender equality, women's empowerment and greater attention to the specific and particular rights of women. What is also clear here is that, in the realm of international politics, Barbados 
presents itself as conceptually aligned with the provisions of most international instruments addressing women's rights and women's empowerment, and makes effort to be perceived as such.

The "internationalization" of law is a concept heavily promoted in human rights circles and, through these circles, makes its way into the international gender paradigm and its approach to policy. Enquiry into the application of various conventions and agreements in Barbados often query the extent to which these agreements have been made law in the domestic realm. The move toward "internationalization" of domestic law and policy is being considered within the Constitutional Reform Commission in Barbados, especially with regard to gender discrimination and other rights-based concerns. This recommendation has been welcomed and continues to be reiterated by the international community (Human Rights Council of the United Nations General Assembly 2008). This reiterates the relationship between the international gender paradigm and state-level policy and decision-making.

As with the international gender paradigm, the Barbadian state addressed gender equality as an issue to be solved through scrutiny of laws, policies and institutions for elements of gender-based discrimination. However, there is some variation in the statelevel assignment of severity and causality. The Barbadian state emphasizes historical attitudes and related socialization as the major obstacles to gender equality in the nation. Discriminatory laws and practices are presented as an inheritance from the colonial system - a system which does not coalesce with the lived realities of men and women in the island. The emphasis on historical attitude and socialization is evident in the emphasis placed on the paradox of women's political participation, where long-held opportunity 
and access has not translated into widespread female participation as candidates in electoral politics. The government juxtaposes the low rates of female decision-makers with the long-standing female political posts at the highest level. The emphasis placed by the government in highlighting female household headship also supports this idea of overlapping realities, as the government describes it as a long engrained practice that parallels a certain level of economic independence among females.

Where Barbados has stepped outside of the dominant mold, is in its introduction into the international discussion of gender-based discrimination against men and boys. Although not extensively detailed in its reports, Barbados highlights raised concerns among its populace on the status and treatment of males. While they make specific mention of possible shortcomings in access and experience of education for males, they implied that more empirical information was needed to substantiate the perspective. They did, however, report more in depth consideration on the issue of paternal rights.

The government noted that the Bureau of Gender Affairs in Barbados sought to establish links with various men's organizations, and has worked in particular with the Men's Educational Support Association (MESA), providing funding for MESA's selfdevelopment and counseling program for its members as well as for other men focused workshops and programs (Barbados Bureau of Gender Affairs 2004). The Report of the Secretary General to the Fiftieth session of the Commission on the Status of Women of the United Nations Economic and Social Council on follow up to the implementation of the Beijing Platform, while highlighting some of the policy commitments Barbados had made to women's empowerment, also highlighted the Government's support of the men's organizations (particularly MESA) and its promotion of discussion on gender 
issues from the perspective of men (Economic and Social Council Commission on the Status of Women, 2005). At the international level, Barbados has noted the concerns of their citizens about male gender discrimination in the Universal Periodic Review of Barbados to the Human Rights Council of the United Nations General Assembly. In the 2008 Report, in presenting the challenges to forwarding human rights in Barbados, the delegation noted that:

"In particular, the MESA raised concerns about the presence of gender discrimination in some of the provisions of the Maintenance Act of 1984 which applies solely to children born outside a marriage. Under section 6 of the Maintenance Act a single woman may make application to a magistrate for a summons to be served on the man alleged by her to be the father of the child. However, there is no corresponding provision under the Maintenance Act for a single male, in similar circumstances, to apply for a maintenance order" (Human Rights Council of the United Nations General Assembly 2008).

Policy emphasis in Barbados has reflected a moderate assimilation of the international gender paradigm. While Barbados aims to promote a society which "accepts gender equality as a national goal" (Barbados Bureau of Gender Affairs 2004) emphasis has been on encouraging women to take advantage of the opportuniteis available to them. The emphasis on encouraging women's full political, social and economic participation has been paralleled by some emphasis on reshaping the spaces of gender interaction in promoting co-education and in addressing the way that girls and feminity is represented in and addressed in educational content and practice.

The emphasis placed by the Barbadian state on raising awareness of gender dynamics and promoting attitudinal change has definitely been salient at the local level, resulting in both change and challenge. The increased scrutiny of law, policy and practice in Barbados to ensure that women do not face negative discrimination has come with 
increased scrutiny of wording and application of law, policy and practice towards boys and men. As Barbados has pushed its domestic legislative and policy agenda toward a paradigm of women's empowerment, a rousing debate on the status of males in society has ensued, a debate that has played itself out in the public media and is paralleled throughout the Anglophone Caribbean. The chapter which follows explores this debate through the period of the 1990s and into the first decade of the 2000s, and it discusses the links between the discourse on gender on the ground, and the very visible efforts of Barbados to show itself as aligned with the international gender paradigm. 


\section{PERSPECTIVES OF GENDER IN BARBADOS}

By the start of the 1990s, the Government of Barbados was doing plenty to raise public awareness and increase the public consciousness on issues of gender equality and women's empowerment. The government had utilized a number of public forums, including radio call-in programs, television panel discussions and feature articles in the print media (Committee on the Elimination of Discrimination against Women 1994). From the government perspective, the general public seemed reasonably comfortable with the legal and social progress made by women, but some were finding it difficult to accept the changes. In discussion of their report to CEDAW of the period 1987-1989, the government noted that some "back-lash" has been felt as a result of the progress of Barbadian women and the governments' legislative and policy changes, and also highlighted the role of civil-society in organizing public discussions on the issues (Committee on the Elimination of Discrimination against Women 1994). The current chapter will explore this assessment of attitude to gender equality in Barbados by presenting public perspectives of gender and gender dynamics.

\section{Sourcing Public Perspectives: Mining the Media}

The current chapter will use discussions within print news media to outline the perspectives of gender and gender dynamics at work on the Barbadian social landscape. The relationship between news media and public opinion is well established and accepted across various social science fields. As early as the 1920 s, journalist and political commentator Walter Lippmann presented mass communication, and more specifically, news media, as shaping people's world view (Lippman 1922). Applied most readily to the impact on political reality, the theory of media's "agenda-setting," posits that the 
subject choice, length and positioning of news media articles and/or broadcasts, have a positive influence on the salience and perceived importance of a given issue in society (McCombs and Shaw 1972). In other words, the press "may not be successful much of the time in telling its readers what to think, but it is stunningly successful in telling its readers what to think about" (Cohen 1963, 120).

The idea of the agenda-setting power of the press was further expanded upon in the development of an expanded socio-psychological approach to content-analysis termed "framing." The theory of framing is attributed to sociologist Erving Goffman (1974), and is built on the idea that people rely on preconceptions and expectations to make sense of their everyday life (Reese 2008). The theory/model suggests that the media presentation of any given issue is designed to promote a particular understanding of the problem, lead to a specific orientation of causal inferences and/or lead the audience to particular recommendations or solutions (Entman 1993). As expressed by McQuail and Windahl (1993), framing is not necessarily a strictly linear process, and can be somewhat cyclical in nature, such that existing perceptions on salient issues affect the way that given messages are interpreted, and may also color the content of the given issue within the news media. As such, the current chapter looks to news media as both an arbiter and reflection of public opinion.

The current chapter will chart the public perspectives through articles in the newspapers of the Nation Publishing Company Limited (the Nation), the island's leading daily. The analysis in the chapter focuses on print media because of its reach, and also because of the general perception that print media, compared to other news media, is a more authoritative source for politically relevant information and awareness of social 
problems (Chaffee and Frank 1996). As a result of the detail with which newspaper stories are able to present social issues, as well as the greater interactivity of print media with the readers' existing thoughts and beliefs, newspapers can have a stronger effect on their audiences than other traditional media on the problem orientation of given issues (Benton and Frazier 1976). In Barbados, despite rising Internet and television access, newspaper readership continues to be a wide reaching public information source. Reports from the Systematic Survey on Newspaper Readership in Barbados in 2005 placed 93 percent of the population as casual and/or daily newspaper readers with the papers of the Nation being five times more widely read than the other local daily. The newspapers of the Nation reach an average 155,657 readers per day (57 percent of the population) and 196,200 on Sundays (72 percent of the population) (The Nation Publishing Co. Limited 2005). In addition the Nation newspapers appear to promote a high level of interactivity through regularized publishing of letters to the editor and guest columns on salient issues. Articles were sourced from the electronic archive of the Nation Newspaper, which houses all articles from 1993 to the present and some prior articles as well. Articles were chosen by running two searches, one for the terms "women and gender," and another for the terms "boys and girls and gender." These search terms were chosen on the basis of the policy changes and gender concerns highlighted by the government in its presentations to international bodies (see Chapter II). Each of these searches found articles for the period containing any or all of the terms used. As a result, hundreds of articles were found, covering the period 1993 through 2010. In order to select those articles most relevant to the current analysis, articles were then selected if they compared the social and/or economic status of males to females, if they compared or described 
perceived male and female roles and behaviors, or if they made a categorical assessment of the social and/or economic status of either males or females. On the basis of these criteria, 120 articles were selected for analysis. These articles were summarized and mined for topic, tone, and perceptions of causality. The articles were found to fall into 5 broad categories: feminism and the women's movement, gender and education, gender and employment, gender and policy, and gender and society. Gender and society and gender and education were, by far, the most popular topics of discussion (see Figure 10).

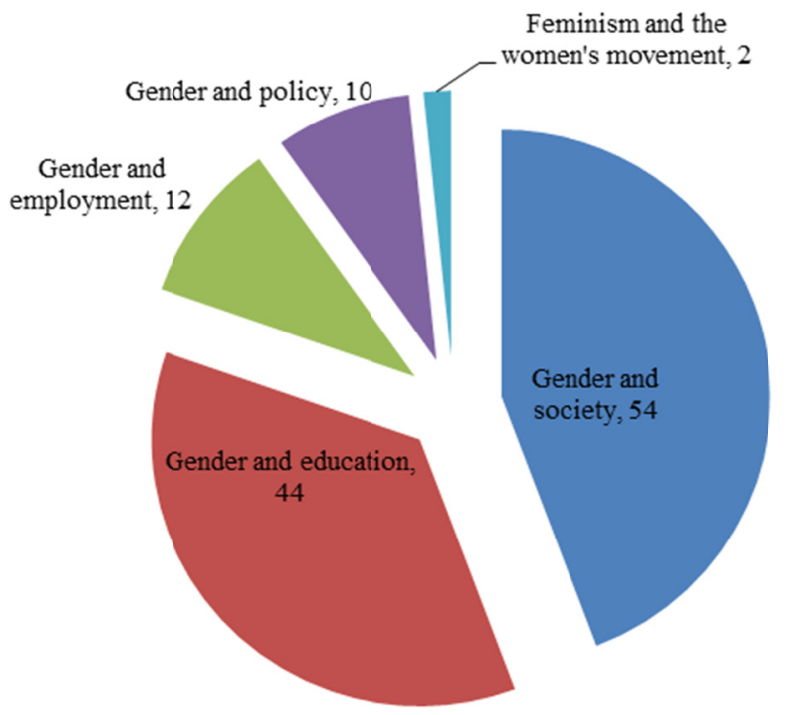

\section{Figure 10: Categorization of Selected Articles}

Through analysis of these articles the current chapter will not only present the dominant perspectives of gender and gender dynamics, but will draw out the alignment of the major points with government action on gender both at the national and international level. It will also highlight relevant research to cast light on some of the deeper reasoning 
fuelling the discussion. This chapter will thus uncover multiple layers of framing of the Barbadian gender dynamic and draw out the relevant inter-linkages and idiosyncrasies.

\section{Perspectives on Feminism and the Women's Movement}

While only two of the selected articles discussed feminism and the women's movement directly, they did provide insight into the way these phenomena are presented to and by the general public. The first article, published August 1995, highlighted the work of NOW on its twenty-fifth anniversary (Banfield 1995). The article echoed the sentiments expressed by the Barbadian government regarding the strength of the women's movement in Barbados. It outlined the involvement of the NOW in forwarding women's rights and influencing effective, empowering gender policies at the national, regional and international levels. The second article, published in 1998, forwarded a similar sentiment, recalling not only the strength of the women's movement in Barbados and the wider Caribbean, but also its early establishment. The 1998 article reported on a presentation by renowned Caribbean feminist, Rhoda Reddock, at the First Caribbean Feminist Encounter, held at the Association of Caribbean States headquarters in Trinidad \& Tobago on 11-13 December 1998, in which she described the women's movement as rooted in the women's self-help societies which were formed in the nineteenth century. These societies, first catering to upper and upper middle class women, soon expanded to middle strata organizations championing women's political, economic and legal rights (Morgan 1998b).

The strength and activism of the women's movement on the ground in Barbados is thus reaffirmed through these articles. However, these articles also raise a question 
regarding the category of women to whom this activism is most readily directed. Inevitably, any activism directed at the rights of women will be to the advantage of all women in a society; however, the effects of these improved rights and the resulting raised awareness, may differ across various social strata and household configurations. The conversation on gender and society within the Nation newspapers certainly alluded to this reality.

\section{Perspectives of Gender and Society in Barbados}

Fifty-four of the 120 articles selected from the Nation archives made direct reference to the social dynamics of gender, addressing the community and household roles of both males and females. As illustrated in Figure 11 below, these articles addressed various subtopics, including the importance and means of achieving true gender equality; gender preference in children; feminization, matrifocality and the general status of women in society; masculinity and male marginalization; relationship dynamics; male familial roles; discrimination and violence against women; women's socioeconomic position; women's socioeconomic advancement; and women in politics. A look at these articles begins to reveal some of the layers of Barbadian gender dynamics.

While only two articles held women's socioeconomic position as their main topic, they both presented a similar interpretation of women's position. They both presented women as both leading and trailing behind. The first article, published in 2007, reported on a presentation by then Minister of Social Transformation Trevor Prescod to the United Nations Commission on the Status of Women. Prescod noted that though women accounted for some 70 percent of students in tertiary education, they also accounted for 
around 60 percent of those below the poverty line (Best 2007). Similarly, the 2008 article, "Some More Equal..." addresses the question, "Are women really equal in the Caribbean?" and suggests that, in Barbados, while the necessary legislation, policies and opportunities are in place, abuse and poverty are still mainly women's problems. The presentations in these articles would suggest that, as alluded to by the fervor and activism of the women's movement, and implied by the focus of the presentations of Barbados to the international bodies focused on women's rights and empowerment, despite long-held access and opportunities, women are just now taking advantage of opportunities to advance their economic status en masse. The presentations also substantiate the statelevel framing of gender dynamics, which emphasizes the need for attitudinal shift and other psychosocial remedies in order to achieve gender equality on the island.

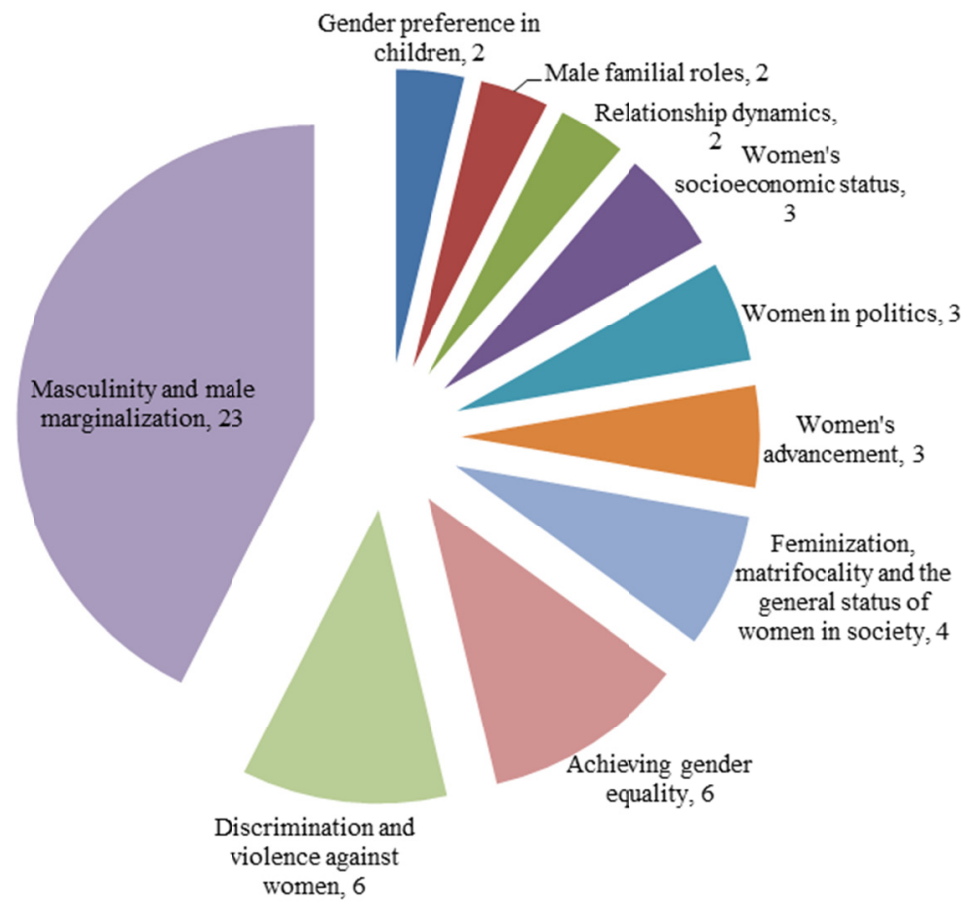

Figure 11: Subtopics in Gender and Society 
The perceived need for psychosocial remedies to issues of gender inequality and discrimination is echoed in articles addressing women's advancement. Of the articles selected, three addressed this issue directly. The first, dated December 18, 1998, summarizes an interview with the Director of the Bureau of Gender Affairs, Marva Alleyne, in which she discusses progress made in the elimination of discrimination against women. In the article, Alleyne suggested that while the laws were becoming more favorable toward women, there were still inherent social biases that needed to be overcome. She said, of the Bureau of Gender Affairs and Government of Barbados:

What we have done over the past 21 years in relation to women is that we have done a lot of consciousness raising... the life practices are what have to be addressed. Because even though you have amended your legislation, it does not mean that everything is hunky-dory (Ejimofor 1998).

Similarly, a 2006 article recalling a presentation by then Advisor to the Prime Minister on Poverty, Hamilton Lashley, suggested that while women's status is improving much more needed to be done. The advisor suggested that poverty, domestic violence and job discrimination remained serious road blocks to the upward economic mobility of women.

A few of the other articles found, which addressed gender in society, seemed to support this position regarding attitudinal obstacles to women's socioeconomic advancement. Two articles on violence against women were found that augmented the attention to attitudinal obstacles. The first of these more recent articles, published March 2009, suggested that the socialization practices in the Caribbean make it an unsafe society for women. The 2009 article quotes then director of UNIFEM's Caribbean office, Roberta Clarke, who suggested that the Caribbean is unsafe for women because of high homicide rates on many islands and an ingrained culture of domestic violence, which are 
linked to the socialization of "restrictive and harmful gender roles" (Springer 2009). The second article described violence against women as a global problem and commended international efforts to raise awareness through the International Day of the Elimination of Violence Against Women (Hardt 2009). It is important to note that, while the tone of these two articles suggest that they are addressing the Barbadian public and a Barbadian problem, their perspective are from a broad regional context that may or may not fully apply to the Barbadian reality. For example, as highlighted by a 2007 joint report of the United Nations Office on Drugs and Crime and the World Bank - Latin American and Caribbean Regional Office, violence in the Caribbean is no more endemic than in other countries in the world (United Nations Office on Drugs and Crime; World Bank - Latin America and Caribbean Regional Office 2007). In addition, this same report showed Barbados to be one of the least violent Caribbean countries for which data are available. Nevertheless, the perspective of Barbados being especially unsafe and violent towards remains, remains engrained in the discussion on gender dynamics, and adds to the argument that Barbadian gender dynamics are heavily related to elements of social identity and the attitudes toward women and men contained in these identities.

The articles addressing societal discrimination against women also supported this view. Only three of the forty-six articles on gender and society had a primary focus on inherent or systemic discrimination against women. Though each came from a very different angle, they all pointed to a perceived or potential societal failure to fully appreciate the roles women play in society, whether positive or negative. The first, dated June 5, 1999, presented the view of Director of the Centre for Gender and Development Studies at the University of the West Indies, Cave Hill Campus, Eudine Barriteau, that 
replacing the term women with the term gender in research and policy will cause the “erasing [of] women as subjects" (Morgan 1999a). The expression of fear of women's erasure from development discourse suggests that if a focus on women is not made explicit and obvious in Barbadian society that women would be left behind. The fear of women's erasure is somewhat substantiated in a 2007 article by Kenya Holder that suggested that more needs to be done to accommodate for the disadvantages females would have because of lack of exposure to certain forms of knowledge. The 2007 article uses as an example an island-wide competition, featuring a quiz with cricket as the main topic, in which the top four respondents got an opportunity to be ball retrievers during an international cricket event. The author lamented the fact that all four winners were boys. She suggested that organizers should have recognized the historical and traditional bias against girls with regard to cricket. She suggested that the method of selection used should have modeled that used in the placement of boys and girls into secondary school on the basis of results of the Barbados Secondary School Entrance Examination (the Common Entrance); whereby boys are allowed to enter the top secondary schools with scores lower than girls because they have been traditionally out-performed. She suggested that using a similar selection method would have accommodated for girls disadvantage and allow for "equal opportunity." The author was promoting the general notion that processes should accommodate for the historical disadvantage of the relevant gender. Coming from a complementary perspective, in his 2003 article, "Taking Our Women for Granted," retired secondary school principal, John Blackman, suggested that Barbadian society very easily takes the achievement of women for granted. Blackman notes, that even though Barbadian women have historically and continually contributed to 
the development of Barbados at the highest levels, they continue to be overlooked in the distribution of public honors and awards. He especially highlights their contributions in the field of education, and suggests that there should be more schools named after female contributors. He asks of Barbadian society, "Why do we marginalise and consign them [women] to anonymity?"

While the perspective of relative public anonymity of female experiences, roles and achievements remained salient throughout the discussion on gender and society in the Nation newspapers, it paralleled a perspective of women having significant latent and real power in the structure and dynamics of Barbadian society. The most recent of these articles addressed women's advancement and suggested that as more has been done to give women equal opportunities and/or make up for their past disadvantages women have taken hold of these opportunities to advance in society. As a guest columnist, retired high commissioner, Frank Da Silva, suggests that women are, in fact, the number one gender in Barbados, and calls for acceptance of this reality:

There has been a dramatic change in Barbados and much of the world as well and perhaps we need to be honest and recognise the peaceful and welcome paradigm development that has occurred where our womenfolk have more than earned the position as the No.1 gender (Da Silva 2010).

Three related articles addressing gender and society, spoke specifically to women's political power. These articles together called for women's recognition of their latent political power, asking them to use it to positive effect. In the March 1, 2001 iteration of his column "People \& Things," Barbadian political analyst, Peter Wickham, suggested that although women are the majority in society, they have been left out of policy development processes. He suggested that reversing women's traditional exclusion 
is not merely about elevating women to leadership positions but about understanding the quantity of political power women already possess and empowering them to mobilize that power. Similarly, lawyer Ella Drummond-Hoyos, in a 2003 article, noted that female voters had outnumbered males by more than 11,000 in the 2003 election and that women were the majority of voters in every constituency. She lamented that Barbadian women seem unaware of the power they could wield. This discussion on women's political participation sits squarely with the state-level perspective that it is a lack of will among women, fueled by their social identity, which keeps them from being more visibly involved in political life.

Three additional articles from the period sought to address the historical and sociological roots of women's real and latent power in Barbadian society, presenting a culture of matrifocality rooted in the systemic fission of the Afro-Caribbean family during African slavery. Two of these articles recalled presentations by Caribbean historian, Professor Hilary Beckles, Principal of the University of the West Indies Cave Hill campus. The earlier of these two articles, dated June 13, 1999, highlighted the gender bias in the slave family dynamic. The article noted that single-mother families were the only family form officially recognized by slave owners, with evidence found in lists of slaves that named the grandmother, mother and offspring with no mention of grandfathers or fathers. In addition, slavery or freedom was inherited through the mother (Morgan 1999b). The second article reports Professor Beckles' findings that Barbados has had a dominant female population since the colonial period as females were the majority among both slaves and slaveholders. It was suggested that this created a population dynamic in Barbados that established women as significant property owners, 
but also created the only slave population at the time with more women, and therefore the only one with natural population growth (Ejimofor 2003b).

The idea of matrifocality and its effect on the Caribbean gender dynamic is one that has raised much discussion in social anthropological analyses of gender. The term matrifocality has been most often referenced in assessing Caribbean and West African social contexts and describes a structure of household, familial and community-level organization in which the woman is dominant and plays a leading role psychologically and in decision-making (Solien de González 1965, Adesina 2010, Quinlan 2011, Tunåker 2011). While its first application focused its understandings on male familial absence or male fluidity within and across households (Smith 1956), further exploration of the structure has deemed it not merely a consequence of male absence and/or of material relations, but an ideological unit with distinct moral codes that gives primacy to "wombrelations" (Adesina 2010, 14). In the post-colonial societies where matrifocality is a dominant structure the matrifocal system often co-exists with patrilineal ideals and political and economic patriarchal orders (Adesina 2010).

The simultaneity of matrifocality and patriarchy in Barbados is proposed as partial reasoning in understanding why women do not exert more visible decision-making power. As surmised by Professor Beckles in Morgan (1999b) the disconnect between matrifocality and women's limited presence in decision-making bodies has arisen because the original gender dynamic rooted in the formative structure of Barbadian society and culture, was overlain by an opposing structure. The emancipation system established male privilege: instead of women and children first they chose skilled slaves first, leading to many males becoming free and establishing economic and political power 
before women. The historical perspective forwarded here aligns with the more subtle state-level admonition of a layered social structure as a legacy of colonialism.

The reference to the juxtaposition of contrasting social structures by the Barbadian state, served to normalize the simultaneous inclusion in feminine social identity of strength and independence on the one hand and poverty on the other. In the local discussion, emphasis on the layered and interconnected structures drew attention to the friction and tension between them. The local level discussion reveals a society whose culture and historical attitude, on the one hand, promotes and accepts strong, power holding, power wielding women while, on the other hand, it operates, officially, as a patriarchal structure, where males are expected to be the main holders and wielders of power. Twenty-three articles on the topic of gender and society addressed this interplay directly, all dealing with the effect of the dynamic on males in Barbadian society. Nine of these articles sought to define and/or provide an analysis of the contents of Barbadian masculinity, fourteen went a step further to define or refute a perceived situation of male marginalization in Barbados.

Within the articles reviewed, the direct analysis of masculinity and male marginalization spanned the period 1997 through 2009 and came in the form of opinion columns, editorial pieces, letters to the editor, and reports of presentations and interviews of government officials and researchers. Barbadian masculinity, particularly AfroBarbadian masculinity, is presented in the discussion as a casualty of socialization. Patriarchal male privilege, and the attitude it prescribes, is cited in two articles as at odds with the reality of gender dynamics for the majority of Barbadians. Former newspaper editor and social commentator Robert Best, in fact, suggested that in order for men to 
function effectively in Barbados they would have to be re-socialized to eliminate the attitude of male privilege (Best 1997).

The remaining seven articles, dealing directly with the Barbadian construction of masculinity, addressed the very limited psychosocial space assigned to men through the overlain layers of the Barbadian gender dynamic. One such article featured a 2003 lecture by Caribbean sociologist Dr. Linden Lewis, and reminded readers that "men are not born with awareness of themselves: society must impose this understanding on them, as it does in similar and different ways for women" (Sunday Sun 2003). While this article proposed that masculinity as we know it is heavily linked to the processes of capitalism and surmised that the current status of men and masculinity is "bound up with the crises and contradictions of capitalism" the others focused more on the effect of the interplay of gender in Barbadian society.

In the 2003 article, “Gender a 'Man Thing' Too,” William Warner, a research officer in the Bureau of Gender Affairs suggested that men exist in more restrictive psychosocial space than their female counterparts (Haynes 2003). The idea of men's psychosocial restrictions was supported by a James Dobson ${ }^{14}$ piece submitted to the newspaper by MESA that lamented the loss of male identity. It suggested that "many men have lost their compass. Not only do they not know who they are, they're not sure what the culture expects them to be" (Dobson 2005). Comparably, in his 2005 article, "Black Masculinity," former director of the Commission for Pan African Affairs in Barbados,

\footnotetext{
${ }^{14}$ Dr. James Dobson, born 1936, is a Christian psychologist famous for founding and hosting the radio talk show and non-profit organization Focus on the Family. In 2010 he removed affiliation with these, and founded the organization and radio show, Family Talk. Both Focus on the Family and Family Talk aimed to provide free resources and family counseling from a conservative Christian perspective (Focus on the Family 2011, Family Talk 2011).
} 
Dr. Ikael Tafari, related these psychosocial limitations directly to the interplay of the family and societal structure dominant during slavery and the overlain patriarchal system. He suggested that the interplay has left Barbadian men with a destabilized masculinity. In his words:

Historically, Barbadian males were subject to two contradictory overarching sociocultural frameworks. Firstly, coming under the European (later, the North American) sphere of influence, they encountered the full force of patriarchy. While there has never been, as far as I know, any truly matriarchal society in history, unlike African societies where women played central, often leading roles, in these Western societies, women were relegated to an inferior position.

...secondly, under the system of plantation slavery, the Afrikan male could not fulfill his manhood as laid down by patriarchy. For he was deemed less than a man. He was only a 'boy' however old he might be. He did not have the prerequisites of male power - he could not marry, defend his female, father his children. Since man and woman are part of an interlocking unity, this violation of his black manhood had the most destructive long-term implication, not only for himself but for the black woman and the black family. What damage to her femininity did the black woman suffer, being forced to "father" her children? (Tafari 2005).

This view promoted by Tafari reiterates the state-level perspective that the mix of inherited social structures in Barbados leads to the simultaneous dominance of contrasting perspectives and expectations of gender on the island. However, while the state-level application served to explain a seemingly dual reality for feminine social identity and the status of women and girls, its application by Tafari served mainly to describe a masculine identity deemed tenuous at best and facing increasing challenge within a shifting social dynamic.

Another psychosocial element raised in the local-level discussion on Barbadian gender dynamics is homophobia. Homophobia was presented as a significant player in Barbadian masculine social identity. In a 2006 article highlighting the views of the most 
vocal men's organization, MESA, the discussion focused on the decision of MESA to allow bisexual and homosexual men to join the organization so that they can have help with their "problem" (Caesar 2006). This homophobic restriction has been reported as a major shaping factor in the contents of masculinity across much of the Caribbean. Michael Kimmel (1994) and Odette Parry (1996) suggest that, within Caribbean societies, homophobia acts as a policing force shaping and constraining what feelings, actions and attitudes are allowable as a real man. Keith Nurse (2004) also suggests that masculinism is the set of rules by which Caribbean masculinity is judged and supports the Foucaultian notion that it acts as an instrument of disciplinary power in issues of sexuality. As such, heterosexuality would function as a central rule in the construction of masculinity in Barbados and the wider Caribbean.

The fissures in the male experience of gender in Barbadian society were further highlighted in public discussion as culpable in the marginalization of Barbadian males on the one hand, and, on the other, as evidence to refute the notion of any crisis of male marginalization. Of the fourteen articles discussing male marginalization directly, ten began with the premise that men were experiencing some level of systemic marginalization and/or experiencing a social crisis. Among these ten, seven suggested that strong female leadership and/or an overemphasis on female advancement may have been perverted to the point of suppressing male progress. Social commentator Cobin Hinds, in his 1998 guest column, “The Endangered Male," lamented that "most boys are socialised by their mothers, then they meet female teachers in the primary school, and may go on to secondary school and meet more females," and that "many boys will tell you they feel discriminated against by the female teachers." He surmised that these 
phenomena, when coupled with the negative images of the black male in media, were creating a crisis of identity for young Barbadian males. Chief Education Officer Wendy Griffith-Watson also pointed to a probability of discrimination within the education system partially related to the dominance of female leadership in the system. She said that Barbadian society must be careful not to alienate boys through biased practices in discipline and punishment. In an appeal to female educational leaders, she said, "I still belong to a generation that took its role of female leadership very cautiously. We did what we had to do without alienating our menfolk" (Daily Nation 2003). These positions allude to the earlier highlighted notions of latent power among women, suggesting that their social roles have presented them with a level of shaping power and influence that has been magnified by their growing advancement.

Lawyer and social commentator, Angus Wilkie, also stressed on the perceived increasingly feminized structure of society and the educational system as contributing to a growing crisis of Barbadian masculinity (Wilkie 2006). The perspective of Wilkie, however, was much more essentialist in nature. Commenting on the seeming lack of motivation for males to enter tertiary education, Wilkie suggested that because the notion of gender equality exists only in an abstract sense the structure of the Barbadian educational system and Barbadian society are to blame for this lack of motivation. $\mathrm{He}$ suggested that, while women can choose their "natural" child bearing role and/or choose to have an occupation; men are expected to earn income to fulfill their role. As a result, he proposes that the elevation of women over men in the top positions of society acts as further demotivation for men. 
It does not seem natural or instinctive for boys to mirror themselves after women, or to be inspired by women. In short, women instinctively look to men for guidance, and not men to women.

Indeed, the woman has the option that she can bear children or be in a paid occupation. But society expects the man to take that responsibility of maintaining the family, even if the woman is working. That fundamental difference between women and men tends to be overlooked when we advocate gender equality (Wilkie 2006).

The particularly essentialist position here taken by Wilkie was not a common position in the local-level representation of gender dynamics, but it does reiterate the idea of men having a more limited social identity than their female counterparts, boxed in by society's narrow expectations of their role.

Social activist Patrice Daniel responded directly to Wilkie's view, on one hand refuting its essentialist elements while drawing attention to the notion of a detrimentally limited male social identity fueled by narrow expectations. She suggested that greater attention needed to be given to the role of nurture in the formation of Barbadian gender identity and the creation of the expectations assigned to the genders. She suggested also that further research be put into the source of men's seeming disadvantages, but posits that afore mentioned culture of privilege is the main element framing the tone of current arguments:

It would appear that in situations where women are more successful than men, the tendency is to blame the system for disadvantaging men or point an accusing finger at the women for stepping outside of their naturedesignated "roles." While the system may indeed play a part, a focus on the system may blind us to other possibilities such as individual culpability and personal responsibility on the part of some males.

...I cannot help but wonder if gender differences in education would have received so much scrutiny had co-education resulted in consistent under-performance by females instead of by males (Daniel 2006). 
This perceived danger of the role-based argument was also highlighted by Caribbean feminist and head of the Centre for Gender and Development Studies at UWI Cave Hill, Eudine Barriteau. A January 2001 article reported her view that the discussion on male marginalization in the Caribbean was too focused on women. Although she agreed that it is important to research the role of women in any perceived marginalization, she maintained that the issue was much broader with many other components which should also include the study of men themselves (Yearwood 2001).

What is interesting about the perspective presented here is that, while is does not refute that some males may be facing some gender-based disadvantages, it suggests that it may be their own fault - a result of misplaced priorities - and have nothing to do with the system or with the relationship between male social identity and female social identity (gender dynamics). This emphasis on misplaced priorities is an ironic viewpoint as the international gender paradigm suggests that addressing gender equality and women's disadvantages cannot be divorced from systemic considerations nor from examining the relationship of female social identity to male social identity (see Chapter I). The singular or unconnected treatment of men's attitudes and beliefs thus points to a rift in the way that the measures of gender equality, gender discrimination and gender empowerment are applied to the scrutiny of male social status as opposed to that of females.

The logistical elements of the educational system also featured in the discussions of a limited masculinity and male marginalization. Secondary school principal Matthew Farley in a 2008 article suggested that young Barbadian men need more positive role models, specifically within the educational system. For him, the absence of male teachers 
presents a systemic problem both reflecting and purveying a problem of male marginalization. As the discussion on gender and education later in this chapter will highlight, this idea of systemic injustice to men within and through the educational system, is one that weighs heavily in the discussion on gender on the Barbadian landscape.

Ironically, many of the same causal perspectives presented for the case of male marginalization were put forth to refute the idea. For example, in a 2009 article by social commentator Michael David, he suggests that young Barbadian men are not being marginalized, but are facing identity issues. As in the earlier cited comments by Dr. Linden Lewis, he proposes that this identity problem is fueled by geo-political shift and advances in the feminist movement that have shifted the norm of white hegemonic masculinity. Referencing some of the same social dynamics highlighted by Beckles (in Morgan 1999b and Ejimofor 2003b), Tafari (2005) and Farley (2008) as shaping a limited masculinity, he places Barbadian family dynamics at the core of the problem, noting that 42 percent of households across the Caribbean are headed by women and, in addition, schools, churches and social spheres have resounding female majorities (David 2009). His solution to the problem: overhaul the education system and institute a system of affirmative action with regard to hiring male teachers, such as male quotas on the basis of school demographics, or offer greater incentives for males to teach.

As with the perspective forwarded by Daniel (2006), the perspective offered by David (2009) removes the idea of self-concept from the assessment of marginality, thus subscribing to the double standard in assessing gender dynamics. However, it also adds to the insights of the real and latent power of females in Barbados, describing elements of 
women's social power not as evident in the state-level presentation of Barbadian gender dynamics.

From 2002 through 2010, social commentators were calling for a more balanced approach to gender equality. A 2002 article featured the comments of then Director of the Bureau of Gender Affairs, Sheila Stuart, that "while there will be times for specific activities to focus on men or women, it must be understood that these must take place in the context of building positive relationships, bringing about positive change" (Daily Nation 2002b). In this same article director of MESA, Ralph Boyce, also presented the view that "gender must not be a term used conveniently to conceal what is in effect gender inequality." The call for a more balanced approach to gender equality has continued into the present. In a June 2010 report on a presentation by then Acting Prime Minister Freundel Stuart to the tenth Annual WAMM held in Barbados, it highlighted the importance of working collaboratively with men on issues of gender equality, so that even though women may be the focus, solutions do not only address the concerns and needs of women and girls, but the growing concerns of men and boys as well. In the words of Stuart, "men and boys are essential partners in the pursuit of gender equality and no one can deny the emerging gaps affecting men," (Carter 2010).

The discussion on gender and society in the newspapers of the Nation shows some parallels to the political position taken by Barbados at the international level, but with one major caveat. Though the discussion at the international level does introduce concerns about gender discrimination and possible gender-based disadvantages facing men, there is little or no questioning as to the possible relationship of these to the systemic shifts aimed at, or induced by efforts at women's empowerment, except for 
suggesting possible negative responses of males to women's progress. On the other hand, the discourse on gender in society at the local level is marked with significant problematization of a focus on women's empowerment which does not apply equal scrutiny to the roles of gender and gendering in the lives of men. One factor that remained consistent at both levels is the attention to the educational system as a pivotal tool in effecting gender equality and/or discrimination. However, while the state-level discourse addressed the applicability of this tool in modifying women's societal status, at the local level, the discourse also presented a view of culpability of the system in alienating and marginalizing males, feeding a disadvantaged social identity. The following section explores more closely the discussion on gender and education by the Barbadian public.

\section{Perspectives of Gender and Education in Barbados}

The Government of Barbados, in its various reports to the international human rights and women's right bodies, often highlights the important role given to education and the educational system in promoting women's empowerment and gender equality. In its report to the CEDAW for the period 1987-1989 Barbados presented the premium placed on coeducation and equal educational opportunity as both a social and logistical avenue of female empowerment:

The elimination of sex stereotyping in schools has resulted in attitudinal changes to the roles of males and females in the society. These changes have been achieved through the continuation of the coeducation process and the inclusion of family life education in the schools' curricula. This measure has further permeated into the work environment where men are now finding themselves working side by side with women of equal status (Committee on the Elimination of Discrimination against Women 1992a, para. 13). 
As evidenced by the great attention to gender and education within the news media analyzed, at the local level, the role of education and the educational experience in shaping gender and gender relations has been undoubtedly accepted by the general public. Gender and education has been a running thread in the discussion on gender in the news media in Barbados since the mid-1990s. However, the perceived effect of education and the educational experience has not been presented in as clear cut a manner as the government's international position. At the local level, while the general position is that the increased educational opportunity for females introduced with the system of coeducation has been great for women's empowerment and social and economic advancement, the educational experience has been increasingly problematized regarding its effect on male social and economic development.

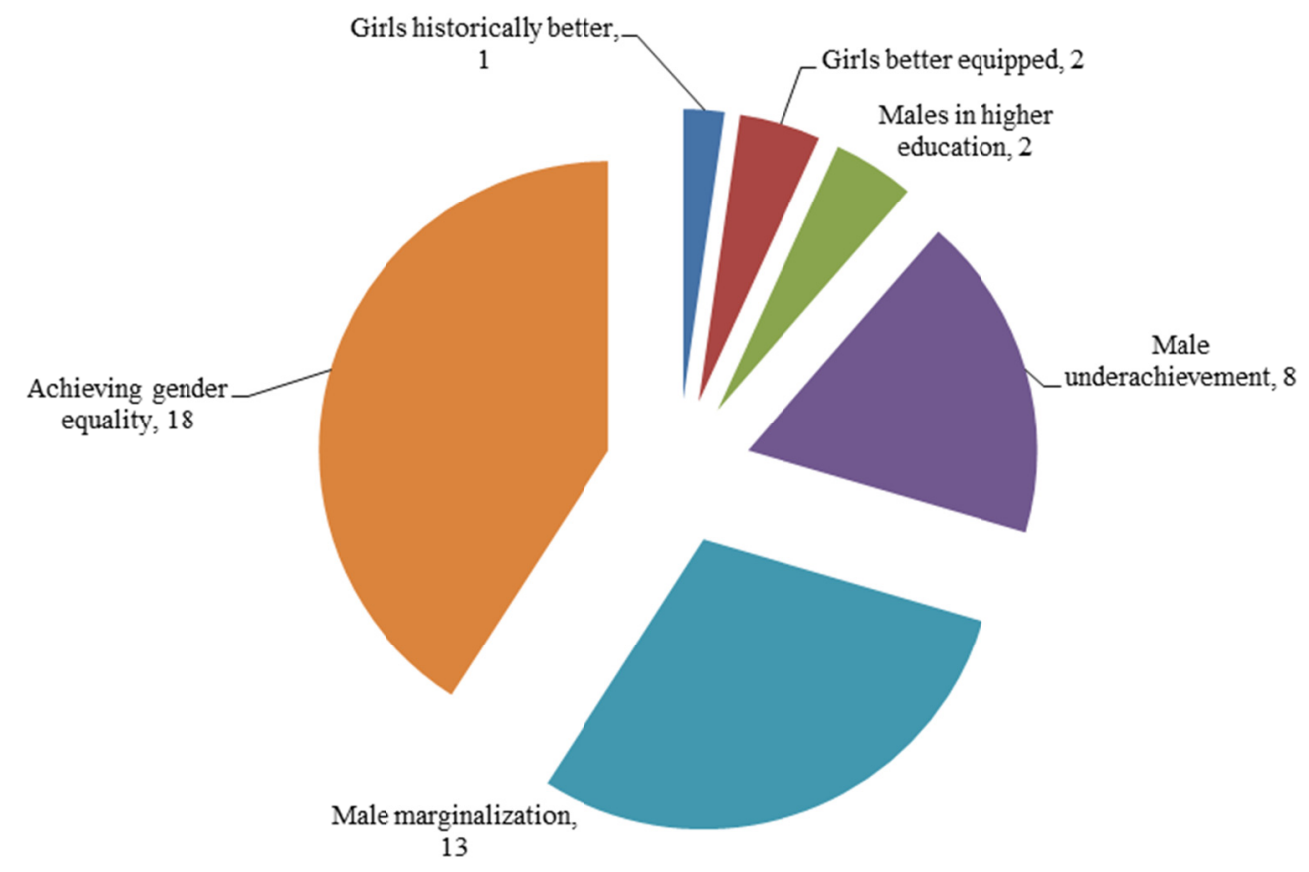

Figure 12: Subtopics in Gender and Education 
Of the 120 articles selected from the Nation news archive, forty-four had a main focus on gender and education. These articles discussed gender and education from six main perspectives (see Figure 12): growing male underachievement, male marginalization in education, reduced male participation in higher education, achieving gender equality, girls' "natural" predisposition to better educational performance, and the idea that girls have always been the better performers in education. Among these subtopics achieving equality through education, male marginalization in education and male underachievement fueled the bulk of the discussion, with article counts of 18,13 and 8 , respectively. However, male underachievement in education remained a running thread throughout the public discussion as a major issue of concern.

The articles with direct focus on male underachievement in education drew reference to the comparatively poor performance of boys versus girls in national and regional level examinations at primary and secondary school. An example of this comes in the 1995 letter to the editor "Statistics Say a lot About Boys in Crisis," which presented data from the 1994 and 1995 Barbados Secondary School Entrance Examination (BSSEE, also known as the Common Entrance Exam), which showed that boys did not score as well as girls. The article noted that in 1994, of the 412 students scoring under 20 percent, 309 ( 75 percent) were boys, and of the 535 in 1995, 482 (90 percent) were boys. The article also noted that in 1994 and 1995, the mean marks for girls in English and in mathematics were 6-10 percent higher than that of boys (Headley 1995).

While the growing and consistently poor educational performance of boys seemed an accepted trend in the articles analyzed, whether or not the problem is a systemic one 
remained a source of contention. Former secondary school principal, and social commentator, John Blackman, in his 1997 article "Boys Outdone in Britain Too," suggested that the problem was a growing phenomenon around the world, rooted in the shifting socioeconomic dynamics wrought by globalization. On the other hand, reports presenting the views of UNESCO and UNICEF suggested that boys' underachievement was their own fault, and rooted in their own misplaced gender perspectives. The perspective that males' poor educational performance was an issue to be addressed at the individual level was echoed by Barbadian educational authorities of the period under consideration by Barbadian educational authorities of the period under consideration.

The article featuring the UNESCO perspective focused squarely on attitudes, suggesting that boys were marginalizing themselves, seeing serious study as an unmanly activity. A UNESCO representative, Colleen Winter-Brathwaite suggested that "in the Caribbean, women are generally less educated than men" (Morgan 1998a). In supporting the argument, the article quoted UNESCO regional data on Latin America and the Caribbean, which reported that of the 42.9 million illiterate people in the region, 23.4 million (54 percent) were women. Similarly, the 1998 article reporting the UNICEF perspective, presented excerpts from "The State of the World's Children 1999," which noted that though boys in the Caribbean did perform significantly worse than girls in school and were more likely to drop out, it was their own rigid ideas about gender roles that affected their capacity to perform in school. The article quoted the perspectives of some Caribbean young men on their performance in school, such as Algie, from Dominica who noted that he "never wanted nobody to tease [him] and call [him] a ‘sissy,” which is why we would skip classes (Sunday Sun 1998). 
The focus on unconnected individual attitudes contained in the discussion in Morgan (1998a) and the 1998 Sunday Sun article highlighted above, shows an acute inconsistency in the application of measures of equality and discrimination when males and not females are the proposed objects. At the international level, attitudes of and about girls and women to school, work, and other socially and economically empowering activities, are seen as naturally subsumed in the cultural, political or other systemic organization of the society in which they reside (Levine and others 2008, UNESCO Bangkok 2005). However, when talking about male gender, attitudes and behaviors deemed detrimental to their development are not seen in this same way, but seen as an intrinsic fault to be corrected at the level of the individual. In parallel fashion, a 2005 article on male underachievement, featuring the perspective of then Chief Education Officer, Wendy Griffith-Watson, presents the perspective that not all boys are underperforming and are, in fact, on par with girls. In support of her position, GriffithWatson cited the results of the 2005 Common Entrance, in which she noted that 42 percent of the top performers were boys. As in the case of the international organizations, this choice of supporting evidence stands out as inconsistent in application to gender and performance in education. Efforts to promote gender parity for females see anything below equal as insufficient. Internationally, differences smaller than this in favor of males, are highlighted as evidence of the need to focus on female empowerment and access. For example, the six-percent difference in male and female illiteracy in the Latin America and Caribbean region highlighted by the UNESCO representative cited above. This example reiterates the double standard at work in the framing of gender dynamics 
and issues of gender equality in Barbados, particularly in reference to male underachievement in education.

For some local discussants of the underachievement of males in education, this bias in the discourse is reflective of a wider systemic bias affecting male development and social status. For example, in an earlier cited 1995 article, Headley presented the problem of male underachievement as a systemic problem, where boys and young men were being held victim to a system biased toward the performance and preference of girls and women. Barbadian educator, Ralph Jemmott, makes the point in a less combative way in his September 2009 article, "Why Males are Lagging." Referencing an article of the British periodical, The Telegraph, he re-asserts that the failure to address male underachievement in education is rooted in a fear of accusation of favoring males over females linked to a mindset of female disadvantage as compared to males. This position points to an important element of the international gender paradigm and its interpretation on a national or local scale. The emphasis has been so much on comparison of the genders, and the components of feminine social identity, that little has been done to explore the components of male social identity with apparent effect on gender dynamics and the male social and economic experience.

\section{Perspectives of Gender and Employment in Barbados}

The local-level discussions on gender in society and gender in education both presented an overwhelming perception of an increasing challenge for men in making social and economic progress in Barbadian society. The discussion on education in the news articles was especially focused on the perception of males' increasing social and economic challenges often referencing the inevitable ill-consequences for employment 
and income generation for males of sustained underperformance and a comparatively low transition to tertiary education. However, in the discussion on gender and employment, the focus was split between growing advancement of women in the world of work, and a continuing struggle for equality for females.

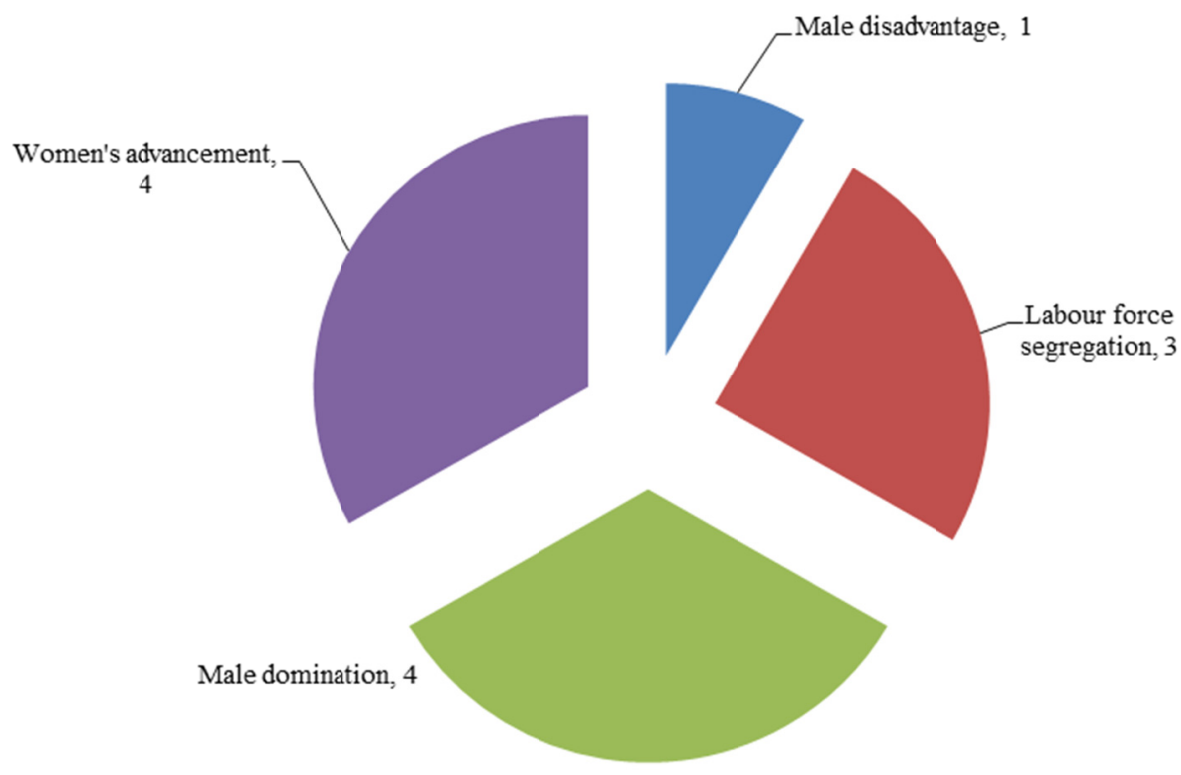

Figure 13: Subtopics in Gender and Employment

Among the selected articles, twelve directly addressed the dynamics of gender in the world of work. Unlike the other areas comparing male and female performance, in this discussion, only one of the twelve articles focused on male disadvantage (see Figure 13). The others addressed issues of male domination, labor force segregation as a female disadvantage, and the advancement of women in the world of work.

In the one article presenting a case for male disadvantage in employment, the author posits that "gainful employment" is a part of male identity, and the combination of employment choices in the small local economy with the number of unqualified males is 
creating a cycle of male frustration and discouragement (Wilkie 2007). This is reflective of the perspective of limited male social identity and narrow expectations, dominant in the local-level discussion on gender and society.

The four articles found on women's advancement in employment suggest a growing, and even domineering, female presence in the world of work. The 1993 article, "Women Taking Over Lead Roles," described women as having thrown off traditional, imposed roles to advance in the business world (Lewis 1993). Improved educational performance at the secondary and tertiary level, coupled with a more progressive attitude among females, was here highlighted as the main cause for this advancement. The author suggests that "the female executive - 'the woman boss' - has now become a part of the working landscape of Barbados." The reference to attitudinal advantage was again made in the 2008 article, "Women Striking out on Their Own," which reported the view of the president of the Barbados Small Business Association that more women than men create small businesses. The president suggested that men were less interested in entrepreneurial development than women, as more women than men seek the services of the Association (Russell 2008a).

The remaining articles addressing women's advancement in employment made an even stronger case on the issue. The August 2007 article, "Women Moving Up" reported findings from the Barbados Economic Society that suggested that women's rate of unemployment was on course to dip below that of men. The article noted that while in 2004 the unemployment rate of women was 10 points higher than that of males; in 2007 it had come within 1.6 points. The article also suggested that younger women were leading the employment wave among females suggesting a continuing trend in the long- 
term (Brandford 2007). In a 2009 article also addressing women's advancement in employment, social scientist and former diplomat, Peter Simmons, makes the point by discussing gender performance in the judicial field. He notes that of the twenty-six lawyers called to the bar in November 2009, only two were male. He lauded the progress of females in the field, but noted also that it may be leading to a case of reverse gender imbalance (Simmons 2009).

In seeming opposition to this view of laudable progress and probable domination of females in the world of work, four of the articles selected addressed a continued male domination in the world of work, despite a growing female educational advantage. The 2005 article, "Glass Ceiling Keeping Them Out," notes that in the 2004-2005 school year at UWI Cave Hill, while 340 post-graduate students were female, only 190 were male. Presenting the view of then director of the Bureau of Gender Affairs, Sheila Stuart, it suggests that the "glass ceiling" still exists, as men continue to dominate the board rooms (Edward 2005). Similarly, a 2008 article reported findings by the Barbados Employers' Confederation (BEC) that only 11.86 percent of corporate board members were women. The article suggested biases in business culture as a probable cause, noting a survey of the BEC which showed institutional mores on women's leadership to be at the core of their underrepresentation (Russell 2008b). Like the state-level discussion on gender dynamics, this perspective highlights societal attitudes as the prevailing challenge to women's advancement.

The other two articles focused on women's discrimination in employment held the general position that women continue to find it more difficult than men to find decent work, and that they receive less pay and benefits than men in similar positions. Both 
articles attempted to bring a non-national perspective to the local situation suggesting that women look at what was going on outside of their own contexts to help them realize and better understand their own situation of disadvantage. The 2007 article, "Women Still Being Sidelined," reported on a panel discussion given in Barbados by representatives of the Centre for Research in Equality and Diversity at Queen Mary University of London. The panel discussion, entitled, "Professional Women as Leaders - Barriers and Opportunities," aimed to give Barbadian women a view of what was happening in Britain in the area of equality as means of comparison and encouragement (Atwell 2007). The article emphasized the elements of comparison in the discussion, such as the wage differential between males and females. Similarly, the 2010 article "Report Shows Gender Gap still Exists" presents findings from the ILO report "Women in Labour Markets: Measuring Progress and Identifying the Challenges.” The article notes that though the report shows the Latin American and Caribbean region to have had the largest gains in economically active women from 1980 to 2008 , across the world, the strongest gains had been in the 1980s and 1990s, and women still continue to be discriminated against in employment.

The remaining articles with gender and employment as the main focus, added to the idea of female disadvantage, suggesting that societal expectations and educational choice limited women to specific career types and wage categories. The March 2003 article, “Liz - Train Women for Men's Jobs,” presents a good example of the overall premise. The article presents the view of then Minister of Physical Development, Elizabeth Thompson who made a call in the Lower House of Parliament for women to be 
trained in non-traditional jobs, as a means of combating their chronically higher rate of unemployment (Sealy 2003).

The discussion on gender and employment reaffirms the perspective of an existing paradox of women's social identity, and of gender dynamics in general. The discussion itself hinges on two opposing viewpoints: that women are becoming increasingly dominant in the world of work, and that women are continually dominated and disadvantaged in the world of work. In highlighting female disadvantage the discussion notes contention at the nexus of females' economic and social positions, noting that a disadvantaged female labor force is a major concern in a society "where the majority of the households are being led by single women with generations of women living in the household, who are themselves having children, and who are responsible for the social and economic fortune of that family" (Sealy 2003).

\section{Perspectives of Gender and Policy in Barbados}

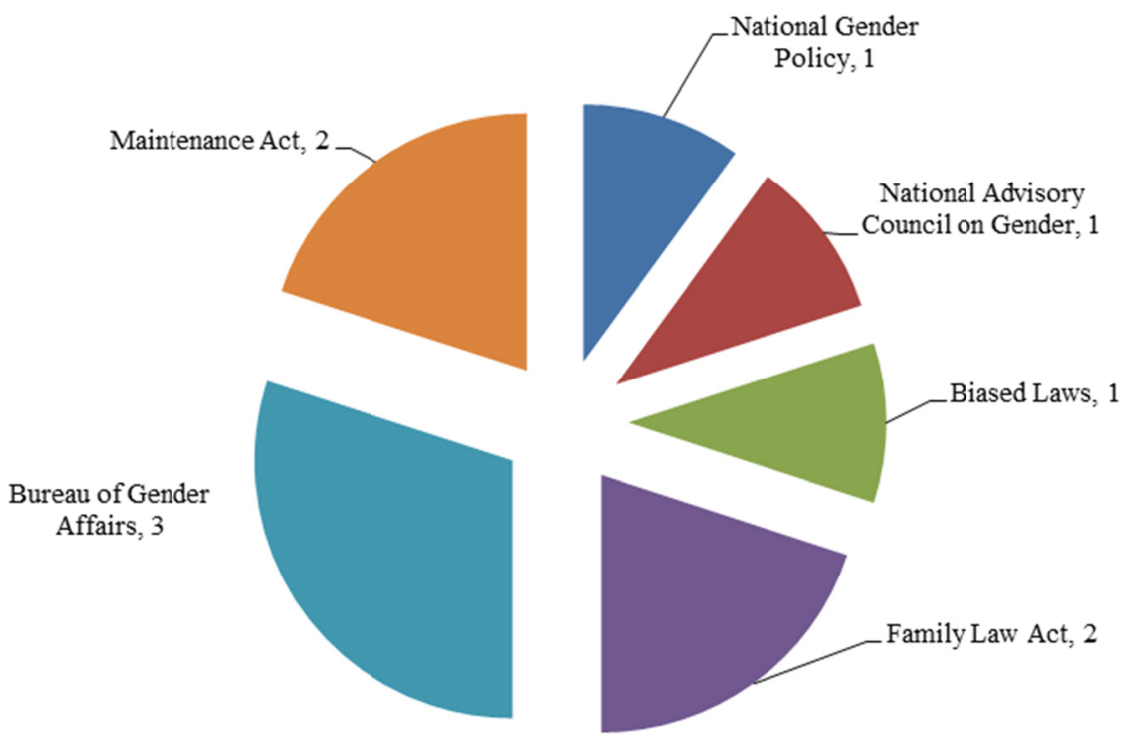

Figure 14: Subtopics in Gender and Policy 
While the 1990s saw the government of Barbados dedicating much focus to the review and revision of laws and policies seen as biased or discriminatory toward women, the discussion in the media analyzed did not focus heavily on this aspect of Barbadian gender dynamics. Only ten of the identified articles directly addressed laws and policies specifically directed at equalizing the genders. The discussion here was equally focused on strides made in the empowerment of women through the policy and legislative changes and on the possible biases that have arisen against men with the institution of these changes (see Figure 14).

A November 1997 article by former secondary school principal and weekly columnist, John Blackman, addressed the historically disadvantaged position of women in labor law (Blackman 1997b). Using interviews from elderly persons, and information from the Report of the Commission on the Status of Women, Blackman presents the law as biased against women. He presents a picture of women, especially married women, as second class citizens, and subject to their husbands. He highlighted their receipt of less pay for equal work and qualifications, and notes that domestic laws discouraged professional women from marriage. He notes also that there have been some improvements since the Report of the Commission. The perspective taken by Blackman (1997b) provides support to the state-level action on gender equality in the 1980s and 1990s, focused on examining legislation for possible discrimination against women and making modifications where necessary (see Chapter II).

In terms of overall policy, three articles summarize the formation of the Bureau of Women's Affairs, and its expansion into the Bureau of Gender Affairs. In summary, the 
articles presented the formation of the Bureau as a good thing for the progress of women on the island, but noted that the male perspective might be lacking, and that this was important to ensure true gender balance and equity. As expressed in the 2000 article "Slow Progress on Gender Bureau:"

Perhaps surprisingly to some men, Gajadhar [president of NOW] has objected that the government committee to study NOW's demands is allfemale, as incorrect in her mind as many boards being all male (Morgan 2000).

In a similar vein, the November 2001 article, "Striking a Gender Balance" addressed the establishment of the National Advisory Council on Gender, and evaluated its functions. The article highlighted that in four of the six functions of the Council (progress on implementation of the recommendations on the National Commission on Women, advice to the minister on specific interests, the investigation of gender-related discrimination, and economic and social progress) reference was made specifically to women. It went on to say that, in these four areas men also have needs. The author thus suggests that the political focus on women is discriminatory against men (Men's Educational Support Association 2001).

Attention to specific laws in the discussion fell squarely on the Family Law Act and the Maintenance Act, two of the laws highlighted by Barbados in international forums as having been modified to better the female position in Barbadian society. Discussion on the Family Law Act presented it as something good for society in general and for gender equality in particular. For example, in the 2007 article "Everyday Law: Revolutionary Changes to Family Law Act” Attorney-at-Law, Cecil McCarthy lauded the changes in the law as taking a more gender neutral approach in determining cause for a 
divorce. Similarly, he noted the recognition of "unions other than marriage" as well as the ability to alter property interests as offering greater protection to women and their children, especially where women's roles in a long-term relationship may have focused on domestic care and other unpaid family work. On the other hand, the related Maintenance Act was condemned in discussion as biased against men, and creating inequalities in the area of domestic rights. For example, the 2004 article "Maintenance Act is 'Criminal"' reported on Member of Parliament Trevor Prescod, condemning the Maintenance Act for sending "too many young black men" to prison for maintenance. He suggested that this perpetuated pre-existing problems of limited skill sets, underemployment and unemployment by adding the stigma of 'criminal' to the men involved. He noted also that the law does not enforce access of the man to his child[ren] even where maintenance is being provided (Sealy 2004). These admonitions were reiterated in 2010 by Chairman of MESA, Ralph Boyce in the 2010 article "Revamp Child Maintenance Act" in which Boyce calls for revision of the Act so that its provisions applied to both male and females and so that it provides visitation rights for fathers.

Attention to policy and legislation was also threaded through the discussions on gender and society, and gender and education. For example, in a March 13, 2003 article focused on achieving gender equality in Barbadian society, journalist, Charmaine McCarthy recalls the recommendations made to Barbados by the UN Committee on the Elimination of Discrimination Against Women on how to improve the situation/status of women. The article speaks specifically to the recommendations for legislation on paternal leave, prosecution of men for "exploiting prostitutes," including "de facto" separation in legislation on marital rape, and introduction of sex education in schools. In contrast, as 
discussed under the category of gender and education, from the mid-1990s through the first decade of twenty-first century, the policy of co-education in public schools came to the fore, first in the form of praise for its propulsion of female status, and then, for its perceived hindrance to male development.

In short, the discussion on gender and policy in Barbados, presented a clear paradox in the perception and understanding of gender dynamics on the island. The growing attention to gender scrutiny of the law on behalf of women drew greater attention to the treatment of men in law and policy. The conclusion: though some positive strides have been made to empower women through policy and legislative change, more still needs to be done, and greater attention needs to be given to the way that some of these same policies and laws discriminate against men.

\section{Conclusion: The Perceived Gender Dynamic in Barbados}

A simultaneous look at the international and local level discussions on gender and gendered relations in Barbados reveals a complex picture. The two discourses, when taken together, reveal gender relations in Barbados as a multi-layered and overlapping dynamic simultaneously influenced by issues of hegemonic masculinity and a matrifocal center. The analysis of the articles from the newspapers of the Nation shows a local-level perception of Barbados as a matrifocal society, where women are seen to be central to the family and community, but where there still exists some patriarchal overtones regarding women's child rearing "duty," as well as discriminatory assessments of their aptitude for political decision-making and business management. At the same time, the educated, working woman and strong-handed family-head and/or community leader are certainly not new notions within Barbadian society, with some commentators referring to women 
as "the backbone of society." However, a growing awareness of men as gendered beings has arisen in the public discussion, with most commentators agreeing that males were moving toward the sidelines of society.

The attention to men as gendered beings could easily be attributed to a backlash phenomenon fueled by an attitude of male privilege ingrained in the patriarchal structure of Barbadian public life. The idea that growing discussion of male gender could be attributed to a male backlash phenomenon is a perspective found in both the state-level and local-level discussion. Some of the Nation news articles addressing male status in the Barbadian gender dynamic did present the improving socioeconomic performance of females as an affront to masculinity, preventing males from performing as well as they could because of increased feminization of social structures, institutions and practices. The argument that systemic shifts have favored females at the expense of males was most fervently forwarded surrounding the issue of education, and the consequential employment and leadership prospects - or lack thereof - that would be afforded boys and men. However, in those articles that lend support to the idea that the discussion on male gender is fueled by mere backlash, there is bias in the application of measures of gender equality and in assigning significance to the relational elements of male social identity.

The chapter which follows attempts to draw the lines between the reality and perception of the perspectives of gender dynamics highlighted in the public discussion as explored through the analysis of news articles in Barbados. By employing a gender analysis of Barbadian social and economic data the Chapter seeks to uncover the foundations (if any) of the arguments presented, with particular attention to the assertion of the growing gender-based disadvantages of males. 


\section{SOCIOECONOMICS AND GENDER IN BARBADOS: REALITY AND PERCEPTION}

In presenting and analyzing the gender-focused content of the Nation newspapers, Chapter III provided much insight into the preconceptions and expectations surrounding gender and gender relations in Barbadian society. It presented a picture of gender relations in which women were seen as significantly empowered though somewhat embattled, and in which men were seen as privileged yet restricted, and increasingly more restricted than their female counterparts.

As previously outlined, these preconceptions and expectations both shape and react to the real and material dynamics of gender in the society. In other words, while the actual social and economic performance of males and females will of course affect the way people view and understand gender and gender relations in a society the reverse and

inverse are also true. The perceptions and expectations of gender relations will also affect how males and females perform socially and economically, with regard to livelihood choices, access to income, and access to services. At the same time, perceptions and expectations about gender relations also affect how people understand and/or interpret the social and economic realities that they see and live each day.

This chapter explores this interplay further, by presenting basic data on the socioeconomic status (SES data) of males and females in Barbados. The chapter will focus on the elements of socioeconomic status most often referenced in the discussions on gender relations at both the international and national levels: education, employment and income, and political participation. Discussion of the data will not only describe the 
objective contents but will also show how the discursive frames at both the international and national levels shape and are shaped by these socioeconomic realities.

\section{The SES Focus of Gender and Development: Outlining the Paradigm}

Much of the discussion in my work has focused on the interplay between the international gender and development paradigm and the experience of gender in Barbados. As such the analysis of SES data are rooted in the nexus of the gender specific SES foci of the international and national level discourse. As outlined in Chapter I quantitative measures of gender equality at the international level focus on educational attainment, economic and political participation and health. For Goal 3 of the Millennium Development Goals (Promote Gender Equality and Empower Women), the monitored targets are the ratios of girls to boys at all levels of education, the share of women in nonagricultural wage employment and the proportion of seats held by women in parliament (United Nations Statistics Division 2008). In the Human Development Report, measures of gender equality have focused on these issues as well as on health.

The discourse on gender in Barbados at both the state and local levels has placed a premium on education both in assessing and promoting gender equality as well as assessing the Barbadian gender dynamic, an element of addressing gender and gender dynamics on par with the international gender paradigm. In both cases, increasing attention has been paid to education at the secondary level and above. However, the local-level discussion on gender and education in Barbados, as presented in Chapter III, has differed slightly from the international paradigm in its added attention to outcomes. As such the analysis in this chapter will not only look at enrollment ratios at the secondary and tertiary levels - measures of gender equality within the international 
gender paradigm - but will also look at available performance data in the Caribbean Secondary Education Certificate Examinations (also known as CXCs) from 1995 through $2009 .{ }^{15}$ As school enrollment is mandatory through age fifteen, in looking at secondary enrollment the chapter will not only look at the comparison of boys to girls as in the MDG indicator, but will estimate the percentage of each population, aged ten to nineteen enrolled in public education. Estimating the rate of enrollment of both the male and female eligible population allows for a more effective gender comparison as it gives insight into access or utilization of education within each gender group.

The discussion of both state and local-level perspectives of Barbadian gender dynamics also shared reference to the labor force participation and employment realities of men and women. As a result of issues of comparability, participation and unemployment rates have been the basic indicators in the internationally focused development literature; however, the qualitative analyses of these data have also referenced labor force segregation, as well as the relationship between employment and education. As such, the analysis in this chapter will discuss participation, unemployment, labor force segregation and, where possible, the relationship between education and employment.

Barbadian gender discourse has also shared the international focus on political participation. Therefore, this analysis will look at political participation referencing not only the share of decision-making positions, but voter participation.

\footnotetext{
${ }^{15}$ In June 2010, I submitted a written request to the Ministry of Education in Barbados for access to statistical information. The analysis of education in this chapter is on the basis of the data provided. See Appendix 1.
} 
Though women's health has maintained a major part of the international gender and development paradigm, little attention has been given to this dimension in the Barbadian gender discourse. As such, this analysis will not explore this aspect of gender equality as it is not perceived as a significant factor shaping or shaped by the perceptions and expectation of the Barbadian gender dynamic.

\section{Gender and Education in Barbados: The Facts}

According to the figures in the GII in 2010, while 89.5 percent of female Barbadians twenty-five years and older have obtained at least a secondary school education, 87.6 percent of males have done the same (United Nations Development Programme 2010). Using enrollment data, provided by the Barbados Ministry of Education, and data from the World Population Prospects 2010, a similar picture is painted. Figure 15 below compares the male and female percentages enrolled in public secondary school from the 1990 academic year through 2008 with the male and female shares in the eligible population in the corresponding calendar years.

Looking at public institutions alone provides a fair picture of educational access and use, as the vast majority of students in Barbados attend public institutions. In fact, in 2008 at the secondary level only five percent of school-aged children attended private institutions (United Nations Educational, Scientific and Cultural Organization 2011). With regard to the age range chosen, in Barbados, the mandatory age of secondary school enrollment is age eleven through fifteen; however, though rare, entry into secondary school can occur as early as age ten, and children who complete the full required course of study to O-Level will leave no earlier than age sixteen if they entered at the common age of eleven. In addition because of the performance-based allocation of students to 
secondary school, schools in the lower seventy-five percent of the rank have modified their teaching pace such that students completing a full course of study through O-Level will be between seventeen and nineteen years of age. Also to be considered is the option to continue to upper secondary school/pre-tertiary education (A-Level) on a competitive basis, on the basis of O-Level performance and space availability. ${ }^{16}$

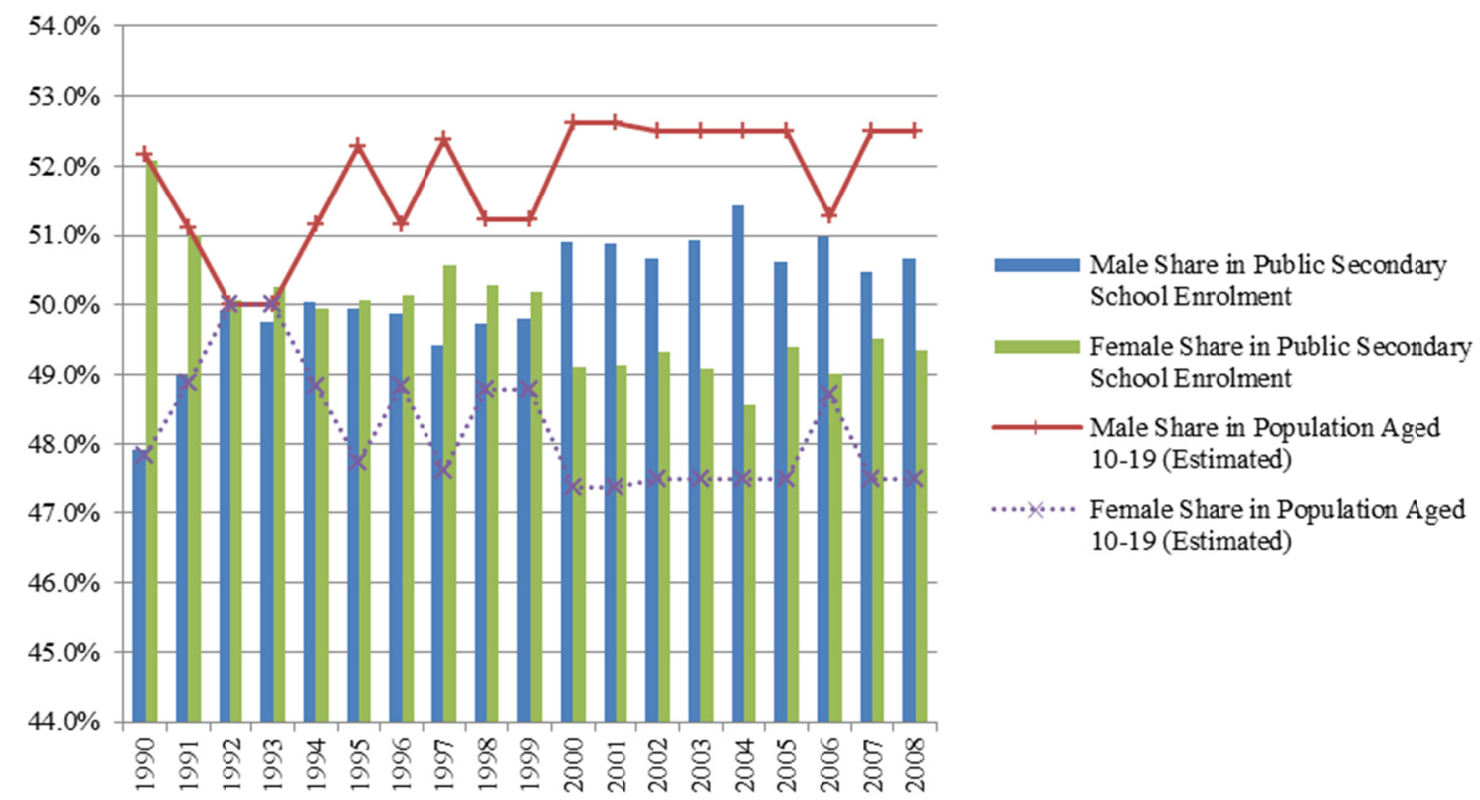

Figure 15: Male and Female Shares in Public Secondary Education Compared to Shares in Eligible Population

Source: (Barbados Ministry of Education n.d., United Nations, Department of Economic and Social Affairs, Population Division 2011)

For most of the 1990s, not only did males maintain a lower share in public secondary school enrollment, but this share was consistently below their share in the

\footnotetext{
${ }^{16}$ Secondary level education in Barbados is divided into two levels of study, O-Level and A-level (Barbados Ministry of Education 2000). Performance at each level is assessed through subject-specific examinations administered by external bodies such as the Caribbean Examination Council and The University of Cambridge. For more information on O-Level and A-Level examinations see The University of Cambridge International Examinations at www.cie.org.uk.
} 
eligible population. From the 2000/2001 academic year through 2008/2009, males maintained a higher share in public secondary school enrollment, but this share was still consistently below their share in the eligible population.

In comparing these findings to the discourse on gender at both the international and national levels, it is easy to see some of the objective factors feeding the discussion. For most of the 1990s in Barbados, there were more girls than boys enrolled in public secondary school in Barbados, with the difference in enrollment shares being highest at the beginning of the decade. As evidenced from the discussion in Chapter II, this period when female shares in secondary school enrollment were greatest coincided with ardent government efforts to remove or reform laws deemed discriminatory against women, as well as promotion of female friendly education and a general increase in efforts at women's empowerment. In addition, at the beginning of the 1990s, universal coeducation would have been only a decade in place - a decade so marked with progressively higher performance rates of girls going into to secondary education, that the Ministry of Education modified the placement system to allot for equal numbers of places for girls and boys in the more highly ranked secondary schools (Mason 2000). In comparing the status of males and females in education, in Barbados, performance in external secondary O-level examinations is an important factor to consider. As in most of the Anglophone Caribbean, in Barbados having attended secondary school for the required time and passing all internal examinations does not necessarily qualify a student for further education or employment. Qualification to pursue any given course of study or to seek employment is most often on the basis of passes, at O-Level or A-Level, in subjects relevant to the desired course of study or occupation. For 
example, for entry into the four-year program for the Faculty of Humanities and Education or the Faculty of Social Sciences at UWI, an applicant must have passed five General Proficiency CXC examinations, or their equivalent, at Grade I, II or III. Of these five passes, one must be English Language, as well as a foreign language, elementary Mathematics, Geography or an approved science subject (The University of The West Indies 2010). For entry into the Business Studies Associate Degree program at the Barbados Community College, an applicant must have six CXC General Proficiency passes at Grade I, II or III, one of which must be Mathematics (Barbados Community College 2011). To pursue a diploma in a business studies subject at the Samuel Jackman Prescod Polytechnic (SJPP), an applicant must have four CXC General Proficiency passes at Grade I, II or III, including English Language, and other subject specific requirements dependent on the area of concentration or an SJPP Certificate in Business Studies (Samuel Jackman Prescod Polytechnic 2011). A look at CXC exam participation and outcomes thus speaks volumes in terms of the gender dimensions of education.

As with enrollment ratios, CXC performance at the beginning of the 1990s could have easily fed a perception of male underperformance and/or disadvantage (see Figures 16-21 below). More than 16,000 students took CXC examinations in 1993. Of these, 6,775 (42 percent) were male. Males also made up a smaller percentage of sitters at the General/Technical Proficiency, comprising about 43 percent of the total. They also comprised about 43 percent of the total passes at this level. With a closer look however, one is able to see that the difference in performance is not as stark as the absolute numbers illustrate. While 82 percent of male exam takers attempted their exams at the General/Technical Proficiency, only 76 percent of females did. The differences in passes 
at this level were also minor, with 84 percent of males attempting non-technical subjects achieving passes versus 85 percent of females and 79 percent of males in technical subjects versus 78 percent of females. Overall, 69 percent of all males sitting CXC exams in 1993 achieved General/Technical Proficiency passes, while 66 percent of female examinees achieved this end.
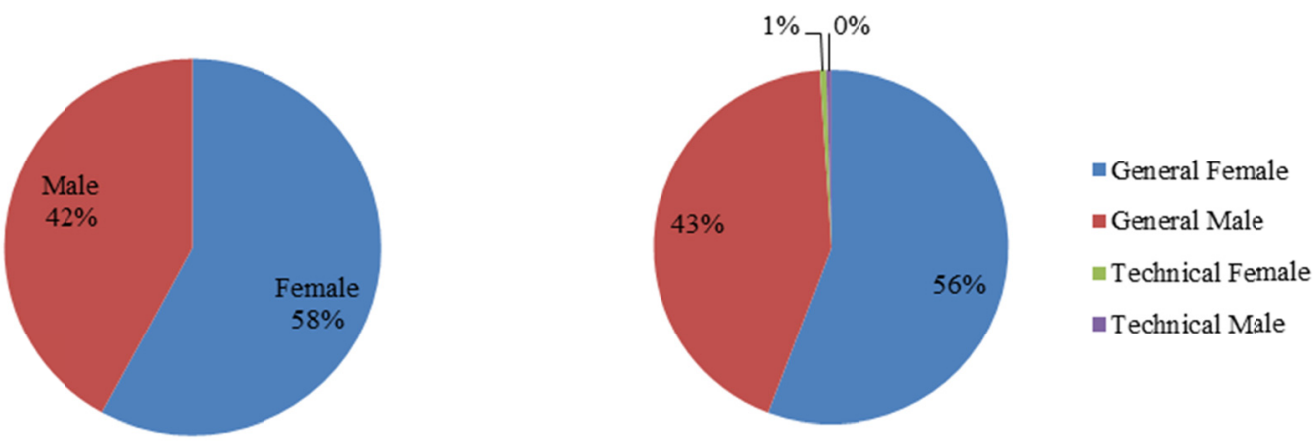

Figure 16: Students Taking CXC OLevel Examinations in 1993

Source: (Barbados Ministry of Education n.d.)
Figure 17: Students Taking General/Technical Proficiency CXC Examinations in 1993

Source: (Barbados Ministry of Education n.d.) 

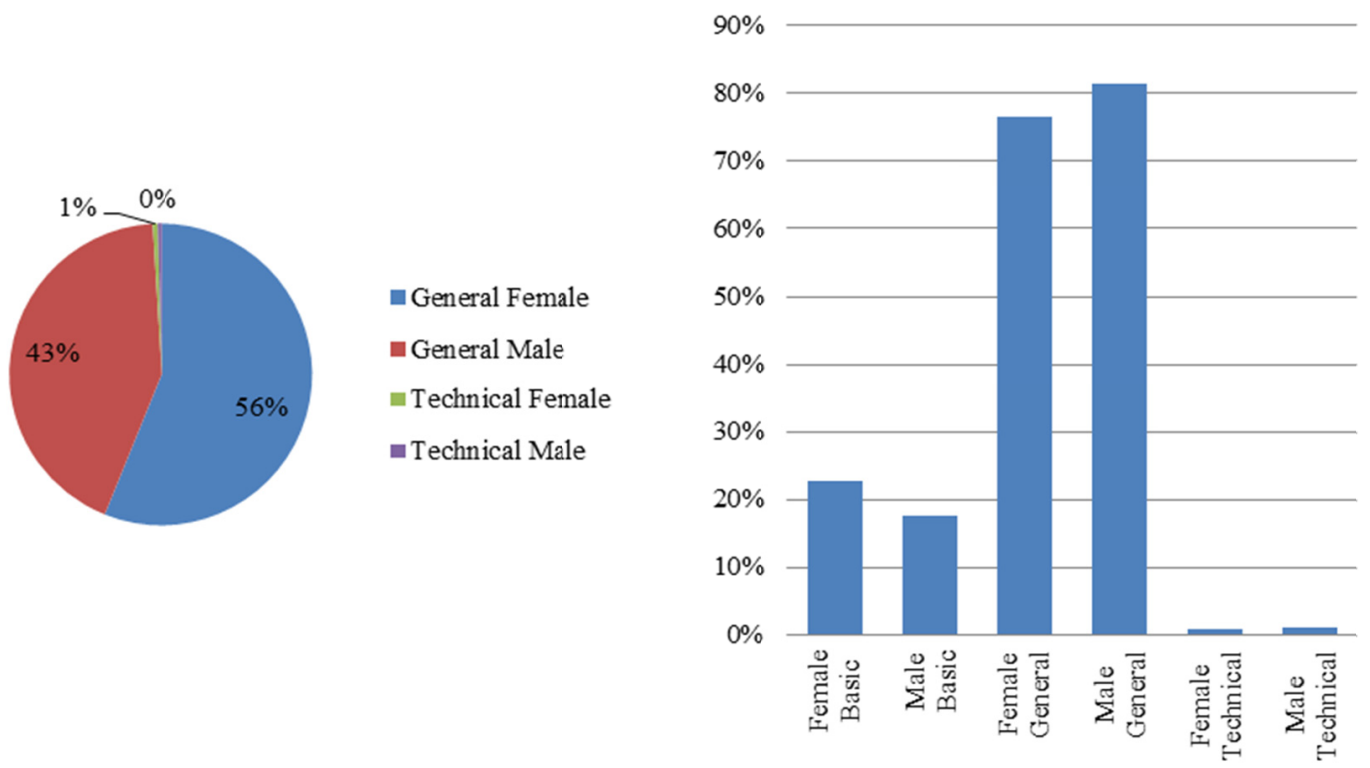

Figure 18: CXC Exam Passes at

Figure 19: Proportion of Exam Takers General/Technical Proficiency in 1993, by Sex

Source: (Barbados Ministry of Education n.d.) Attempting each Exam Category in 1993, by Sex

Source: (Barbados Ministry of Education n.d.)
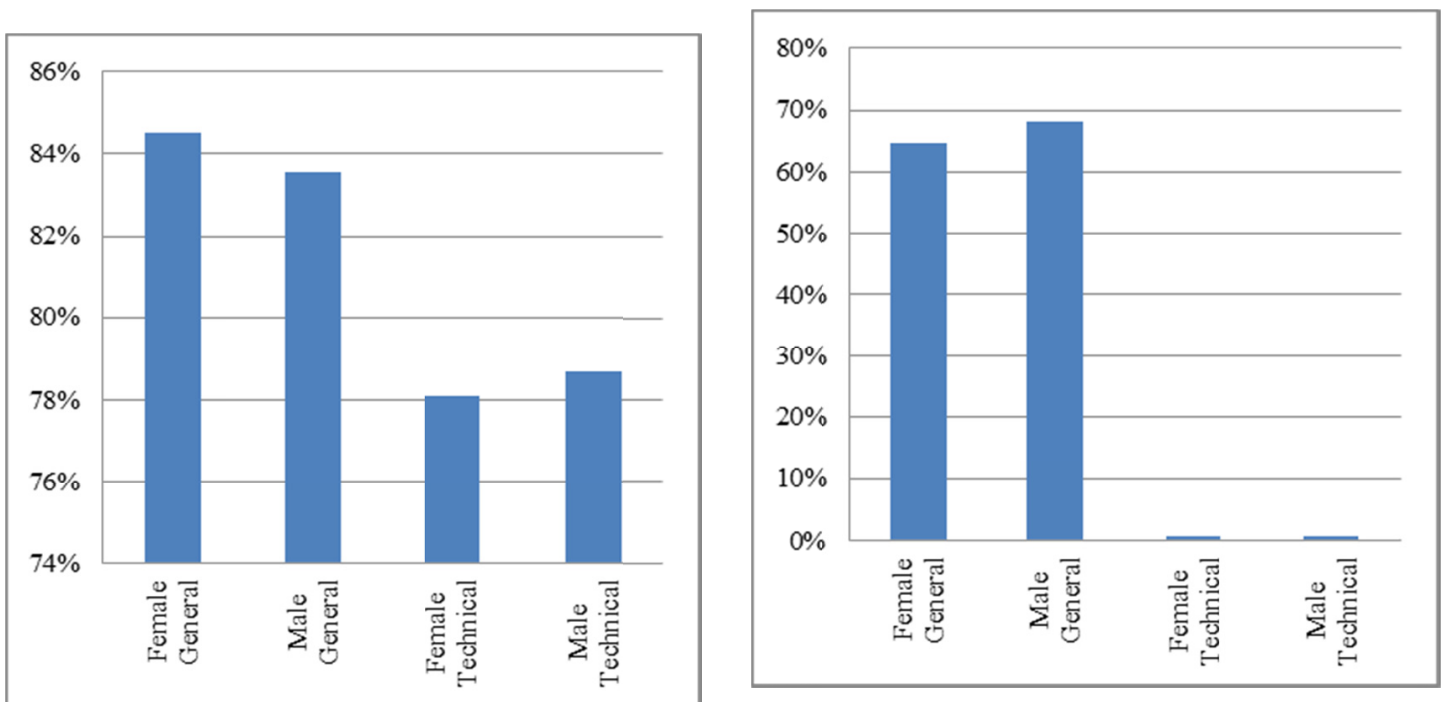

Figure 20: Passing Rate at

General/Technical Proficiency in 1993, by Sex

Source: (Barbados Ministry of Education n.d.)

Figure 21: Proportion of Total Exam Takers Achieving Passes at General/Technical Proficiency in 1993, by Sex

Source: (Barbados Ministry of Education n.d.) 
Ten years later, in 2003, while performance had shown decline for males and females, performance for males had declined more than it did for females (see Figures 22-27). More than 20,000 students took CXC examinations in 2003. Of these, 8,203 (41 percent) were male. Males still made up a smaller percentage of sitters at the General/Technical Proficiency, comprising about 41 percent of the total. They comprised about 40 percent of the total passes at this level. In 2003, only 79 percent of male exam takers attempted their exams at the General/Technical Proficiency, while 84 percent of females did. Passes at this level declined for both sexes in 2003 but the differences in passes from attempts remained small. Of the males attempting non-technical subjects in 200364 percent achieved passes versus 84 percent in 1993, and 67 percent of females versus 85 percent in 1993. In the technical subjects, 64 percent of male attempts achieved passes in 2003, versus 79 percent in 1993, and for females the 2003 passing rate was 57 percent versus 78 percent in 1993. Overall, 58 percent of all males sitting CXC exams in 2003 achieved General/Technical Proficiency passes, versus 69 percent in 1993, while 60 percent of female examinees achieved this end in 2003 versus 66 percent in 1993.

These figures show that as the discussion on gender dynamics and male marginality began to pick up on the domestic landscape, educational performance proved an empirical source fuelling the arguments of male disadvantage. While males were no longer outnumbered in secondary enrollment, they were both outnumbered and outperformed in secondary level examinations. 


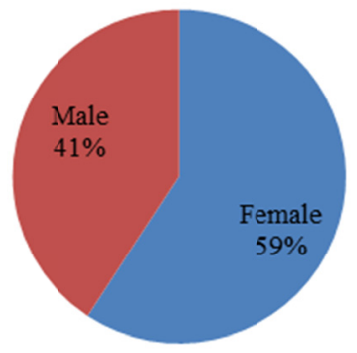

Figure 22: Students Taking CXC OLevel Examinations in 2003

Source: (Barbados Ministry of Education n.d.)

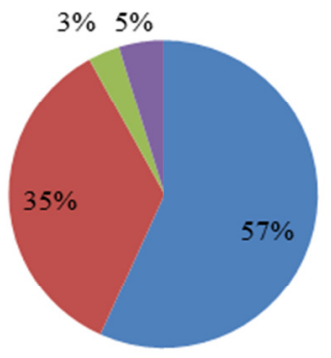

a General Female

- General Male

= Technical Female

- Technical Male

Figure 24: CXC Exam Passes at General/Technical Proficiency in 2003, by Sex

Source: (Barbados Ministry of Education n.d.)

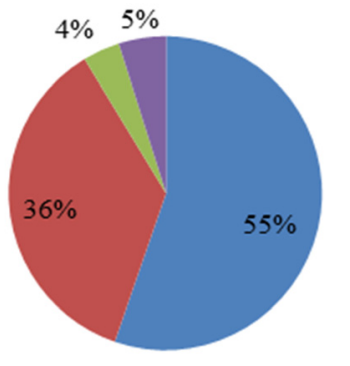

General Female

- General Male

- Technical Female

- Technical Male

Figure 23: Students Taking General/Technical Proficiency CXC Examinations in 2003

Source: (Barbados Ministry of Education n.d.)

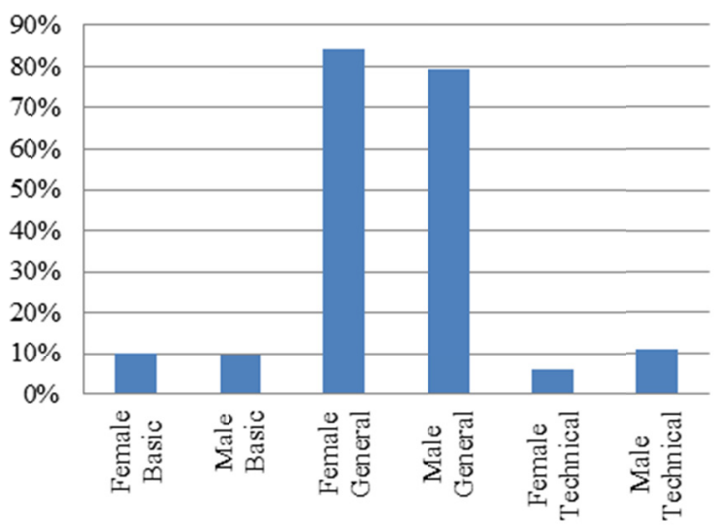

Figure 25: Proportion of Exam Takers Attempting each Exam Category in 2003, by Sex

Source: (Barbados Ministry of Education n.d.) 


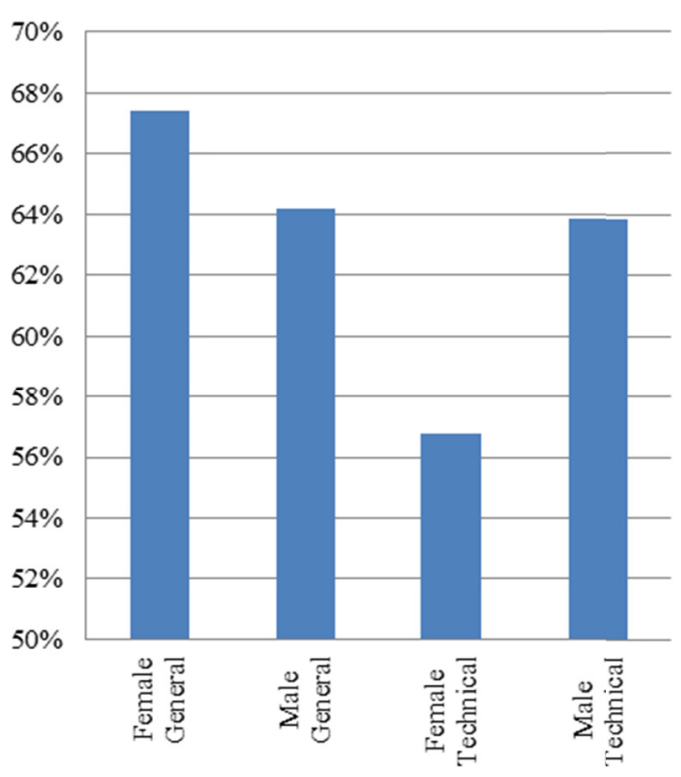

Figure 26: Passing Rate at General/Technical Proficiency in 2003, by Sex

Source: (Barbados Ministry of Education n.d.)

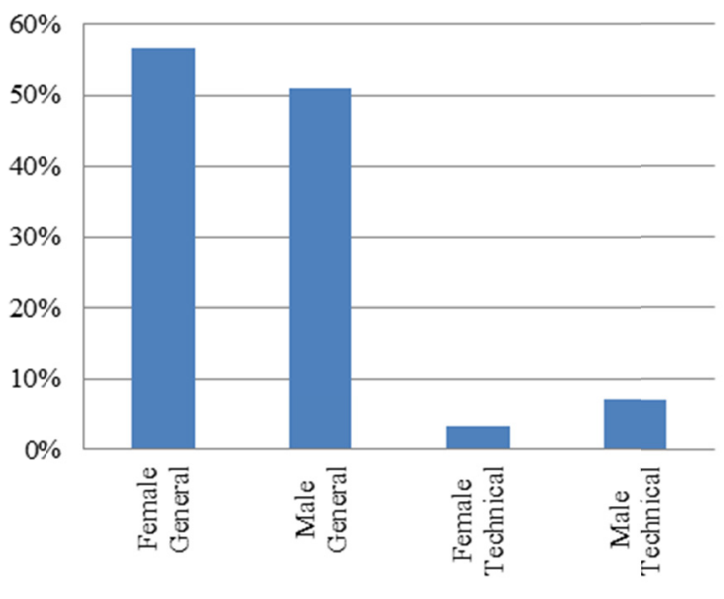

Figure 27: Proportion of Total Exam Takers Achieving Passes at General/Technical Proficiency in 2003, by Sex

Source: (Barbados Ministry of Education n.d.)

The story remained practically the same in 2009 (See Figures 28-33). Males remained the smaller percentage of examinees at 42 percent, and were an equal proportion of the examinees at the General/Technical Proficiency. As in 2003, they maintained a lesser proportion of the passes at this level as well (41 percent). In 2009, greater proportions of both males and female were attempting exams at the General/Technical Proficiency. Ninety-nine percent of male examinees took exams at the General/Technical Proficiency, and 98 percent of female examinees. However, male examinees were now showing a lower passing rate than their female counterparts in both the technical and non-technical subjects at the General/Technical Proficiency. While 63 percent of male sitters at the General/Technical Proficiency attained passes in nontechnical subjects, 69 percent attained technical passes. For females the rates were 66 
percent and 83 percent, respectively. Overall, 63 percent of all males taking CXC exams in 2009 achieved General/Technical Proficiency passes and 65 percent of females.

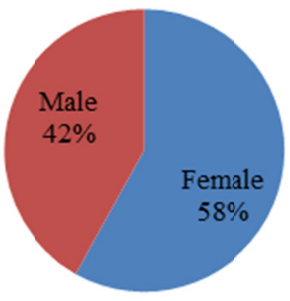

Figure 28: Students Taking CXC OLevel Examinations in 2009

Source: (Barbados Ministry of Education n.d.)

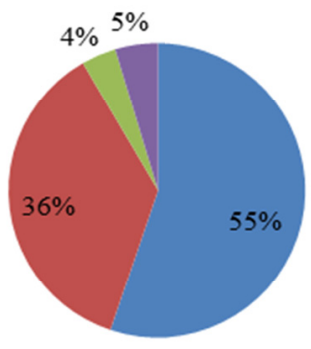

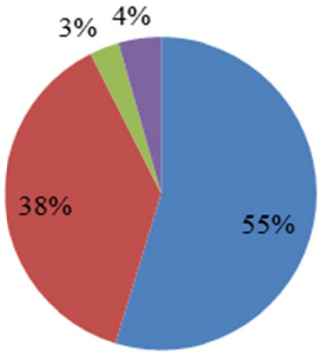

m General Female

- General Male

in Technical

Female

- Technical Male
Figure 29: Students Taking General/Technical Proficiency CXC Examinations in 2009

Source: (Barbados Ministry of Education n.d.)

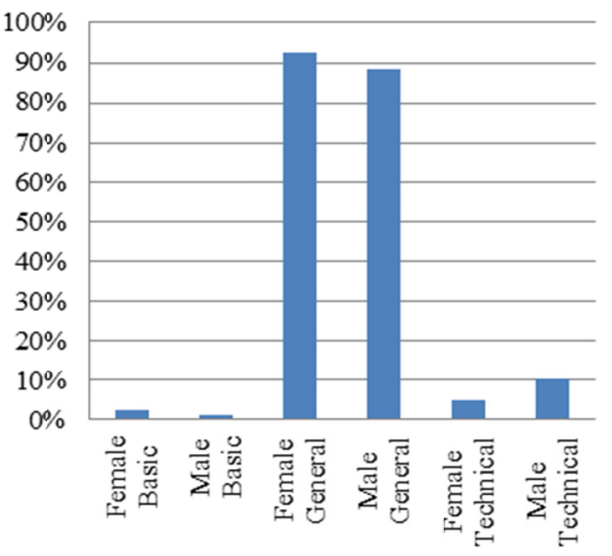

Figure 31: Proportion of Total Exam Takers Achieving Passes at General/Technical Proficiency in 2009, by Sex

Source: (Barbados Ministry of Education n.d.) 


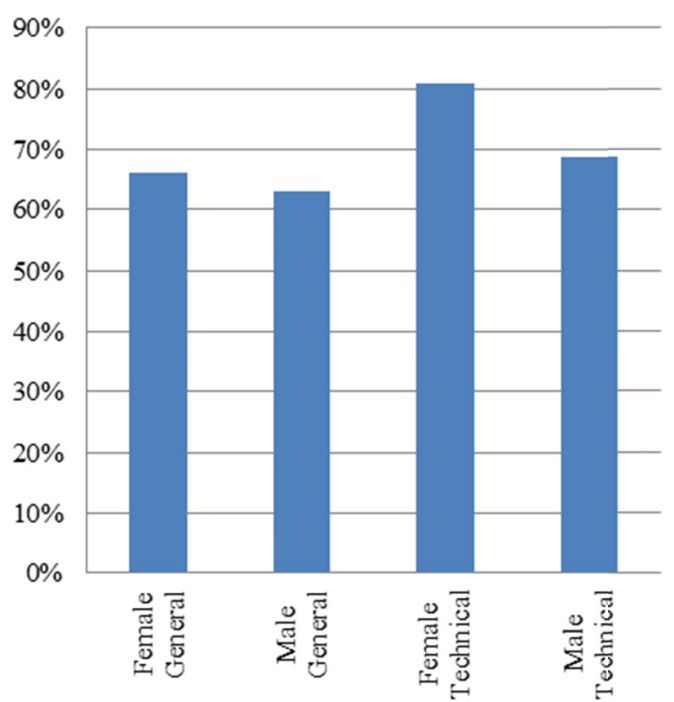

Figure 32: Passing Rate at General/Technical Proficiency in 2009, by Sex

Source: (Barbados Ministry of Education n.d.)

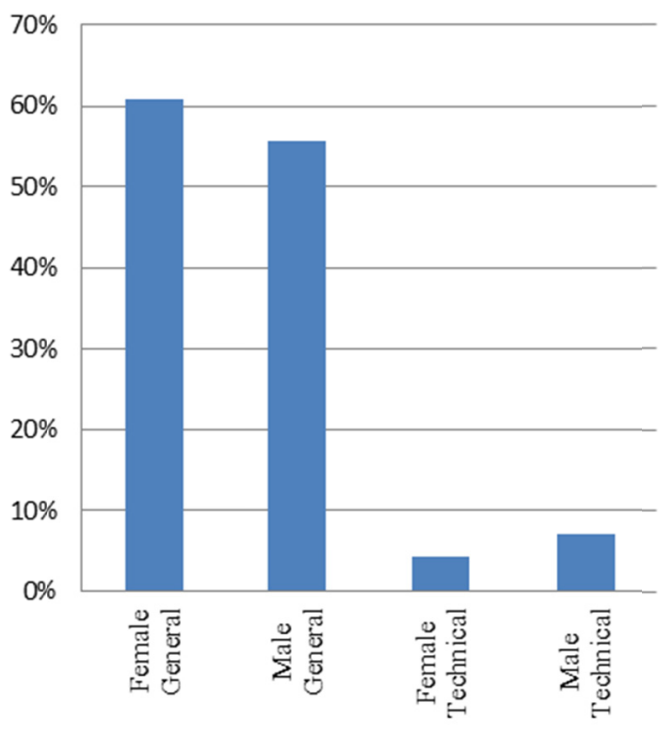

Figure 33: Proportion of Total Exam Takers Achieving Passes at General/Technical Proficiency in 2009, by Sex

Source: (Barbados Ministry of Education n.d.)

While the ratio of males to females at $\mathrm{CXC}$ level has remained fairly consistent since 1993, males comprise a consistently smaller proportion of total tertiary level enrollment (see Figures 34-38). Even at the Samuel Jackman Prescod Polytechnic, where males have been the majority of students, males have seen their share in enrollment decrease from 65 percent in 1995 to 57 percent in 2008. At the more traditionally academic institutions, Barbados Community College and the University of the West Indies Cave Hill Campus, males have comprised less than 40 percent of enrollment, at least since 1990. In addition, males accounted for only 30 percent of tertiary level graduates in 2008/09 (Barbados Ministry of Education n.d.). They made up only 26 percent of graduates from UWI Cave Hill. Though they have been a consistent majority 
at SJPP, males only accounted for 41 percent of graduates from the institution in that year.

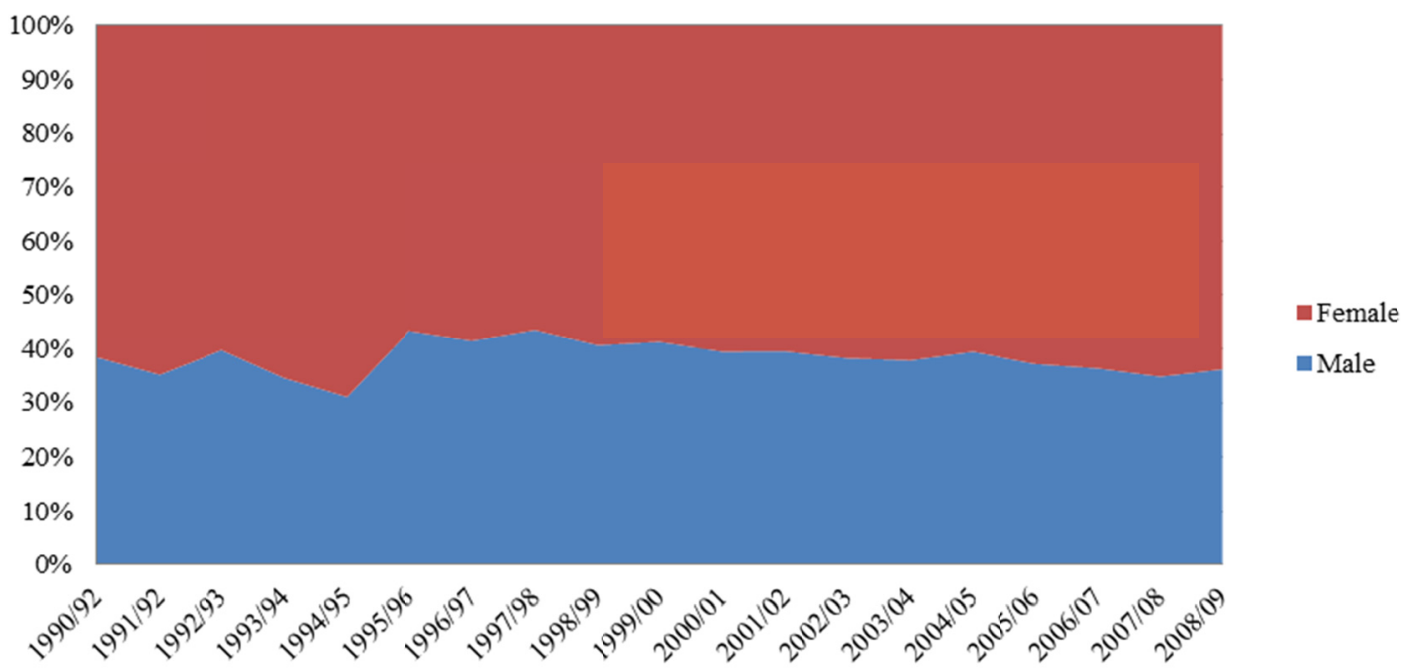

Figure 34: Total Tertiary Enrollment 1990-2008

Source: (Barbados Ministry of Education n.d.)

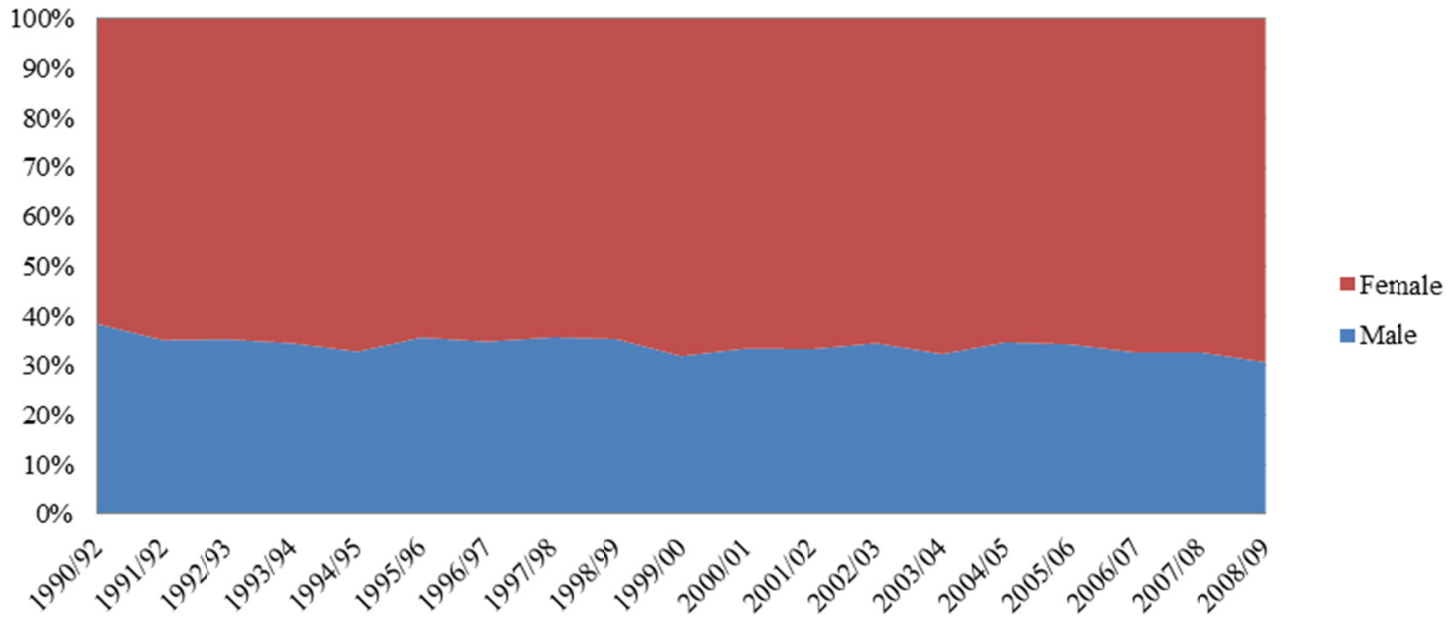

Figure 35: Enrollment at BCC 1990-2008

Source: (Barbados Ministry of Education n.d.) 


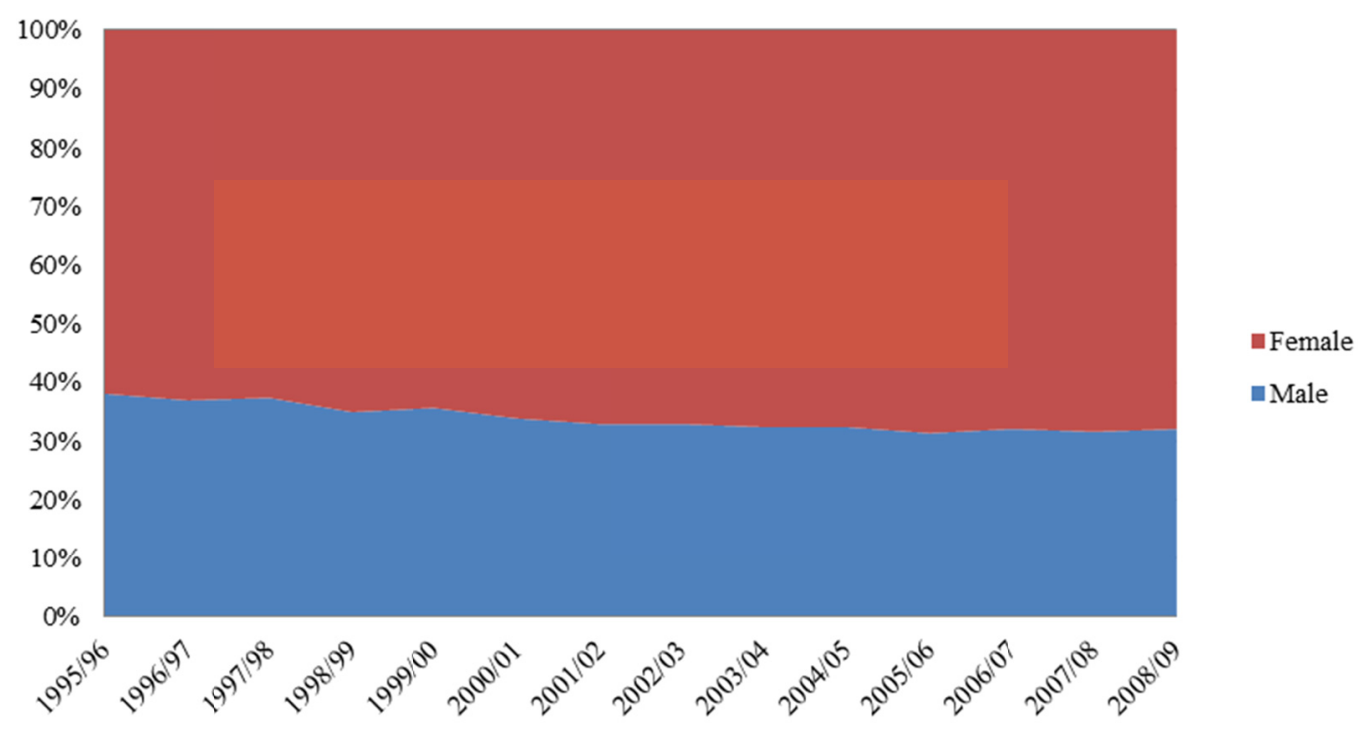

Figure 36: Enrollment at UWI 1995-2008

Source: (Barbados Ministry of Education n.d.)

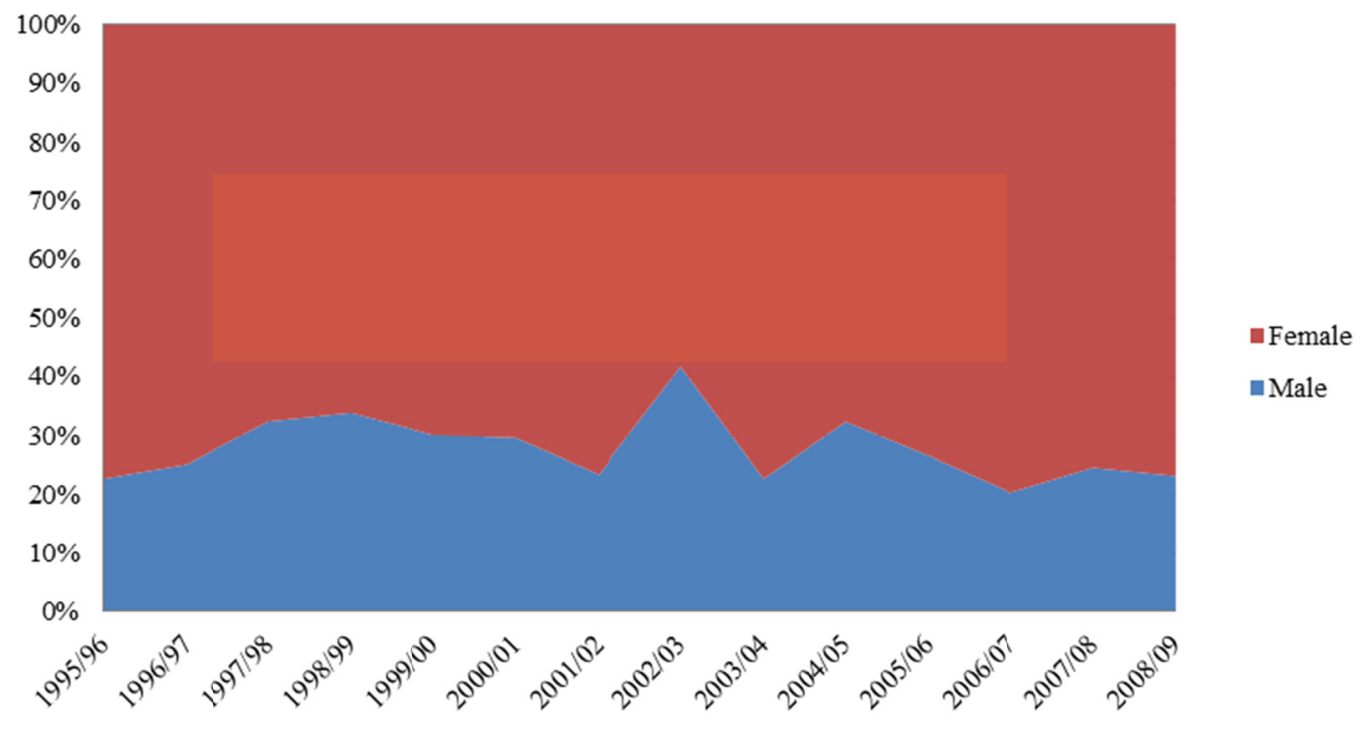

Figure 37: Enrollment at Erdiston Teachers' College 1995-2008

Source: (Barbados Ministry of Education n.d.) 


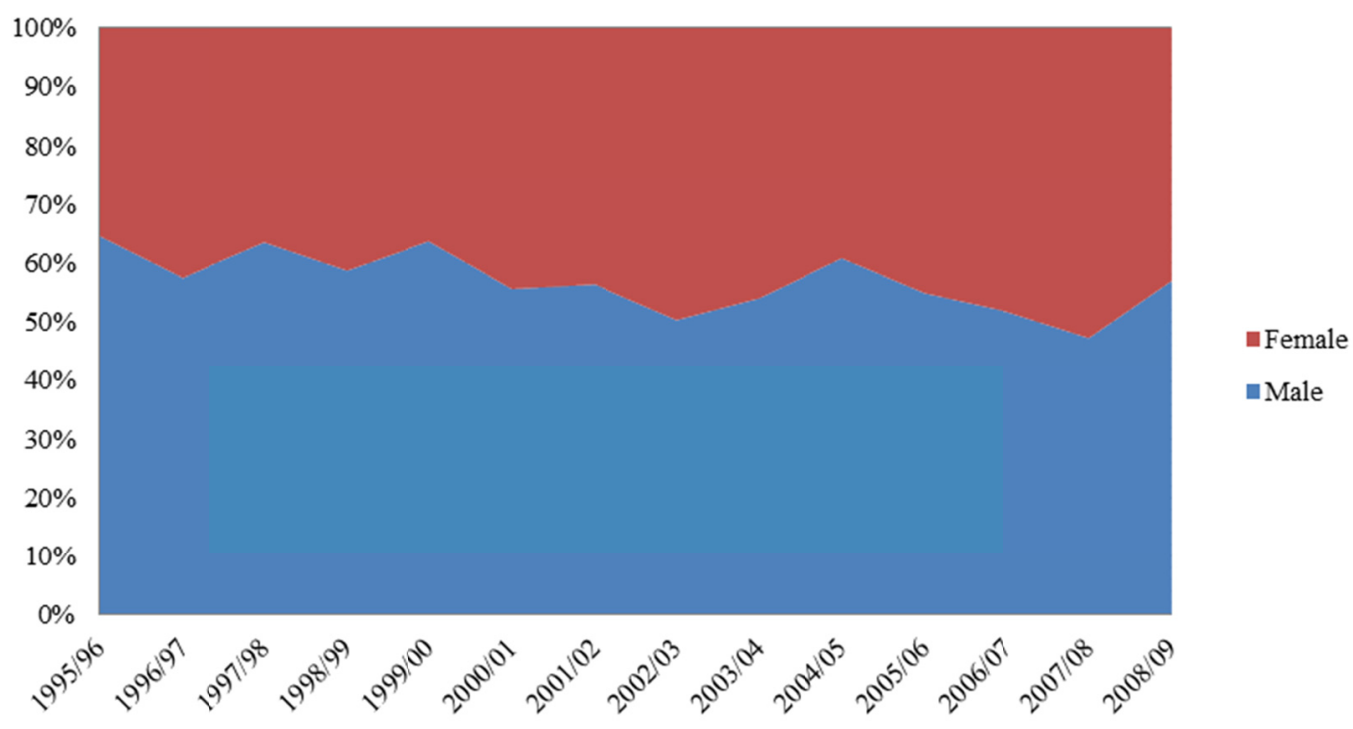

Figure 38: Enrollment at SJPP 1995-2008

Source: (Barbados Ministry of Education n.d.)

These findings complement the discussion on gender and education presented in the news media in the 1990s and 2000s, as discussed in Chapter III, with reference to growing male under performance in education. At a time of heightened international discussion and national government attention to female empowerment, males appeared to be having a more difficult transition to both secondary and tertiary education than were their female counterparts. At both the secondary and tertiary levels, males were outperformed by their more numerous female counterparts. Males have also consistently undersubscribed to the secondary level examinations necessary for tertiary level entry and mainstream employment options.

\section{Gender and Employment in Barbados: Reality and Perception}

Attention to the gender dimensions of education at both the domestic and international levels, not only address access to education as an end in itself, but as a means to future access to employment and improved social standing. Gender analysis of 
educational access and outcome do reflect some elements of a "falling off" in positive outcomes for males. Males appear to be accessing the system at a lesser rate, and performing comparatively poorly, especially with regard to the completion of CXCs, and transition to and graduation from tertiary institutions. However, how do the differences in male and female educational performance translate into social and economic productivity?

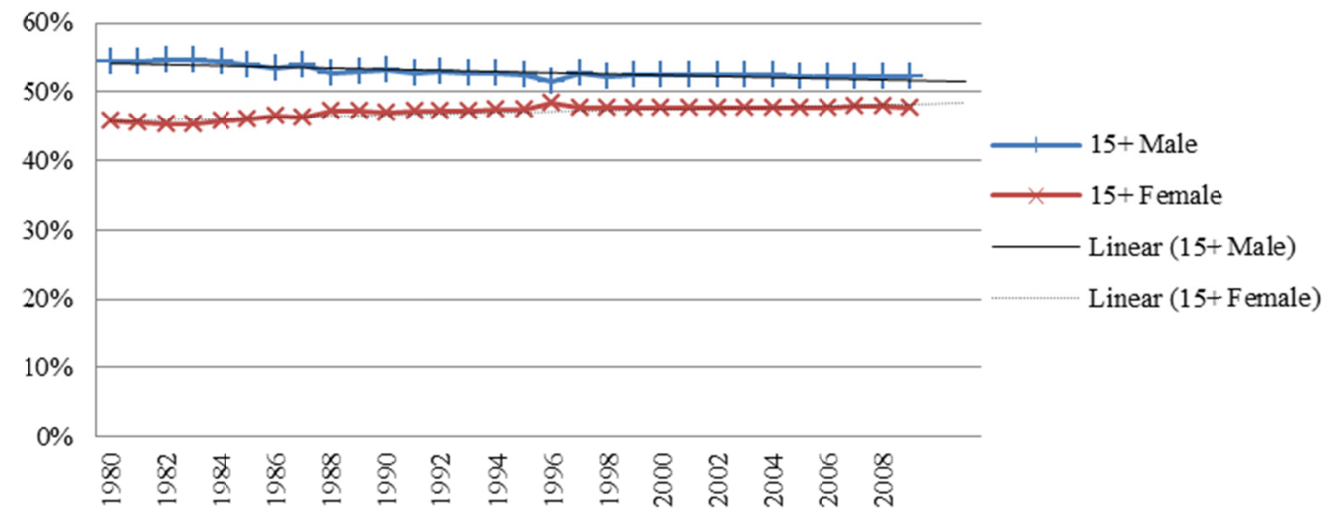

Figure 39: Percentage of Labor Force

Source: (International Labour Organization 2009)

As illustrated in Figure 39, at least since 1980, males in Barbados have been a consistent majority of the labor force. Males have also maintained consistently higher labor force participation rates than their female counterparts (see Figure 40). Barbadian males fifteen years and older, averaged 53 percent of the labor force from 1980 through 2009 , with a range of 52-55 percent. They also averaged a77 percent labor force 
participation rate from 1980-2009, while the female participation rate averaged 62 percent for the same period (International Labour Organization 2009).

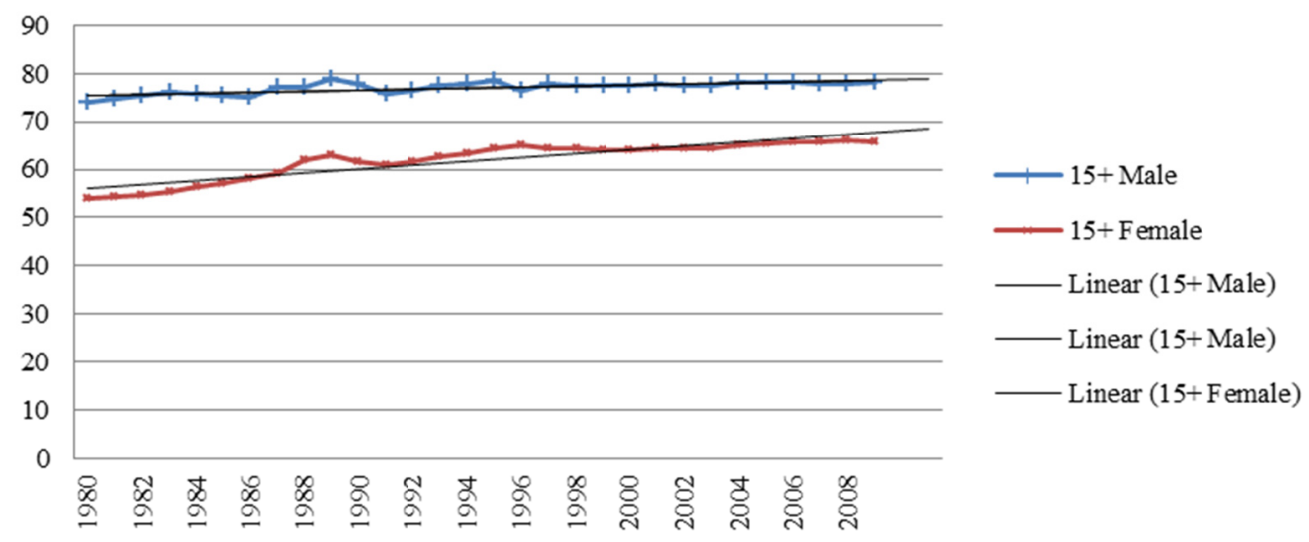

Figure 40: Labor force Participation for Ages 15+ by Sex

Source: (International Labour Organization 2009)

Males have also maintained much lower unemployment rates than females in Barbados (see Figure 41 below). Males averaged an 11.8 percent unemployment rate from 1980-2008, while females averaged a rate of 18 percent. The data on labor force participation and unemployment thus challenge the concern shown on the domestic front regarding male socioeconomic status. The numbers could suggest that females' strong educational performance is not necessarily translating to economic empowerment. However, a closer look at labor force dynamics on the island points to both real and perceptual evidence that could be fuelling the raised concerns.

For one, the earlier outlined weakening educational involvement and outcomes of males parallels converging performance of the sexes on the employment front. During the 
1990s and 2000s, when gender dynamics featured heavily in local discourse, males averaged unemployment rates of 14 percent and 8 percent, respectively, while females averaged 21 percent and 11 percent(International Labour Organization 2009). From 1990 to 2008 , males saw their unemployment rate decline 3.5 percentage points, while that of females declined 10.8 percentage points. During the same period, while the male labor force participation rate increased by 0.1 percentage points, that of females increased 4.4 percentage points. So, just as with education, while there has been a "falling off" of male performance, women have moved forward, albeit in subtle increments.

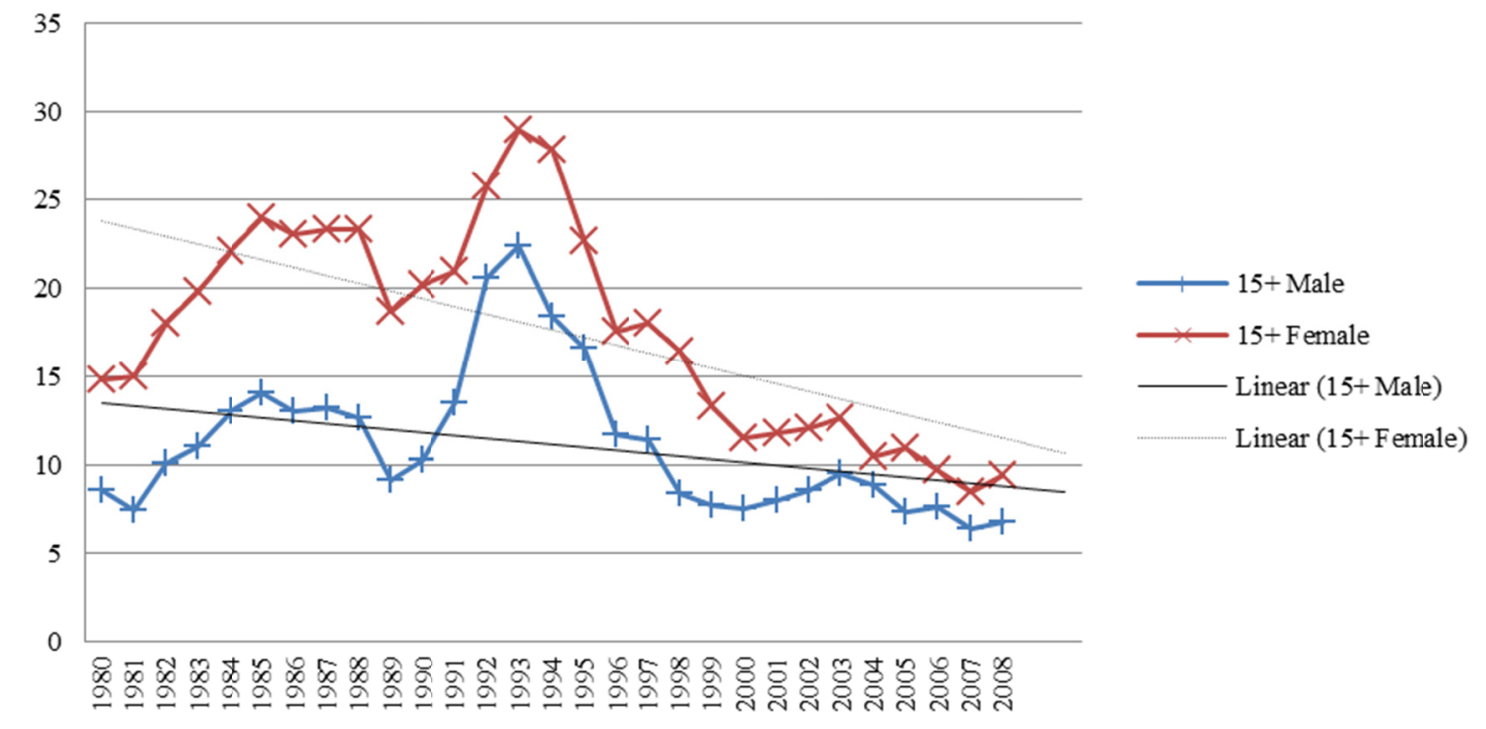

Figure 41: Unemployment Rates 1980-2008 by Sex

Source: (International Labour Organization 2009)

The convergence of male and female unemployment rates does not necessarily indicate that females are taking over, or that men are being disadvantaged as a result. So is the discussion on male marginalization outlined in Chapter III a reflection of 
discomfort with lost male privilege as suggested by some of the more hard-line critics of the concept of male marginalization? Maybe; however, a look at the distribution of the workforce across economic activity and occupation may lend a different perspective.

The ILO's LABORSTA database presents data on employment by economic activity and occupation from 1981-2004. As illustrated by Figures 42 and 43 below, employment segregation across economic activities has been a running trend at least since 1981. For both sexes, employment has been most concentrated in "Community Social and Personal Services," Making up an average 35 percent of male employment and 43 percent of female employment. This category includes employees in public administration and defense, social and community services, recreational and cultural services, and personal and household services. ${ }^{17}$ The next greatest concentrations for males have been in "Construction" and "Wholesale and Retail Trade and Restaurants and Hotels" accounting for 16 and 15 percent of male employment respectively. For females, the next highest concentrations have been in "Wholesale and Retail Trade and Restaurants and Hotels" and "Manufacturing," accounting for an average 20 and 12 percent, respectively.

At the international level, labor force segregation is often highlighted for the limitations it places on female economic activity, with females often relegated to less stable sectors, however, things have played out a bit differently in the Barbadian labor market. As illustrated by Figure 44 below, since 1981, overall employment activity has grown fastest in uncategorized activities (related mainly to the tourism industry), "Community Social and Personal Services," "Financing, Insurance, Real Estate and

\footnotetext{
${ }^{17}$ See Appendices 2 and 3
} 
Business Services" and "Construction". These have increased by 9, 6, 4 and 4 percentage points respectively. Three of these areas, uncategorized activities (related mainly to the tourism industry), "Community Social and Personal Services," and "Financing, Insurance, Real Estate and Business Services" are also the fastest growing employment activities for females, increasing 11, 8 and 6 percentage points, respectively. Male employment activity has grown 8 percentage points in the area of "Construction," but in the faster growing areas, uncategorized activities (related mainly to the tourism industry), "Community Social and Personal Services," and "Financing, Insurance, Real Estate and Business Services" they have increased their activity at slower rates than their female counterparts. Males increased their activity in these areas at rates of 7, 3 and 3 percentage points, respectively. The fields in which females are increasing their shares are also those with consistently high and/or growing shares in the Gross Domestic Product (see Figures $45 \& 46)$. Males have been concentrated in declining areas of employment activity, with female dominated activities increasing their shares. As such, as activities in other areas level off, or decrease, and these areas continue to increase, the perspective of females taking over the employment market is created.

Also of note are the related effects of this sectoral segregation on income patterns. On average, males in Barbados make 14 to 27 percent more than their female peers (Bellony, Hoyos and Nupo 2010); however, as suggested by both the international and domestic level discourse, there is certainly no overall domination by males with regard to wage levels and income security. As demonstrated by Bellony and others (2010), while males do generally earn more than their female peers, females are prevalent at both ends 
of the earnings distribution. In addition, a greater proportion of females work in the highest paying occupational group (Professionals), than do males.

In addition to these numerical observations, also of interest is the nature of the industries and occupations in which males and females are concentrated. If employment activity and occupations are thought of in terms of likely daily interaction with the public, an interesting pattern emerges. Of the ten categories of economic activity, four could easily be categorized as having low daily interaction with the public, "Agriculture, Hunting, Forestry and Fishing," "Manufacturing," "Electricity, Gas and Water" and "Construction." By the beginning of the 1990s these accounted for more than one-third of male economic activity and accounted for around 30 percent in 2004. On the other hand, these accounted for only 18 percent of female activity in 1990, and by 2004 only 10 percent. Males thus appear to be more concentrated in less visible forms of economic activity.

In looking at occupations, the issue of visibility becomes even more pronounced. From 1981 to 1993, ILO classifications of occupational types were "Professional, technical and related workers," "Administrative and managerial workers," "Clerical and related workers," "Sales workers," "Service workers," "Agriculture, animal husbandry and forestry workers," and "Production and related workers, transport equipment operators and labourers". On the basis of the descriptions given, of these six groupings, "Administrative and managerial workers," "Agriculture, animal husbandry and forestry workers," and "Production and related workers, transport equipment operators and labourers" would incur little daily interaction with the general public. By 1990, these accounted for 56 percent of employed males and 42 percent of all employment, while 
they accounted for only 24 percent of female employment. The nature of male occupational segregation reconfirms the lack of visibility of working males in daily activity.

By the beginning of the 2000 s, the classifications had been changed to allow for clearer delineation of the types of tasks involved in a given occupational grouping. The groupings were then "Legislators, senior officials and managers," "Professionals," "Technicians and associate professionals," "Clerks," "Service workers and shop and market sales workers," "Skilled agricultural and fisheries workers," "Craft and related trade workers," "Plant and machine operators and assemblers," "Elementary Occupations" and non-classifiables. On the basis of the main tasks performed in these groupings (see Appendix 3) "Skilled agricultural and fisheries workers," "Craft and related trade workers," and "Plant and machine operators and assemblers" would have little interaction with the general public on a daily basis, and "Legislators and senior officials" would have limited interaction. On the other hand workers in the other categories are more likely to perform tasks in which they directly serve the general public on a daily basis. Except for males in "Elementary Occupations," who comprised an average 12 percent of the employed labor force from 1994-2004, females in high visibility jobs comprise higher proportions of working Barbadians than males. For example, from 1994-2004 females employed as "Service workers and shop and market sales workers" averaged 11 percent of the labor force, while males in that category made up 7 percent of the labor force. Female "Clerks," made up 10 percent, versus 3 percent for males in that category, and female "Professionals" comprised an average 6 percent of the labor force, versus 4 percent of male "Professionals" (see Figure 47). In short, in the 
Barbadian context, sectoral and occupational segregation very easily creates the perception of a female dominated labor force.

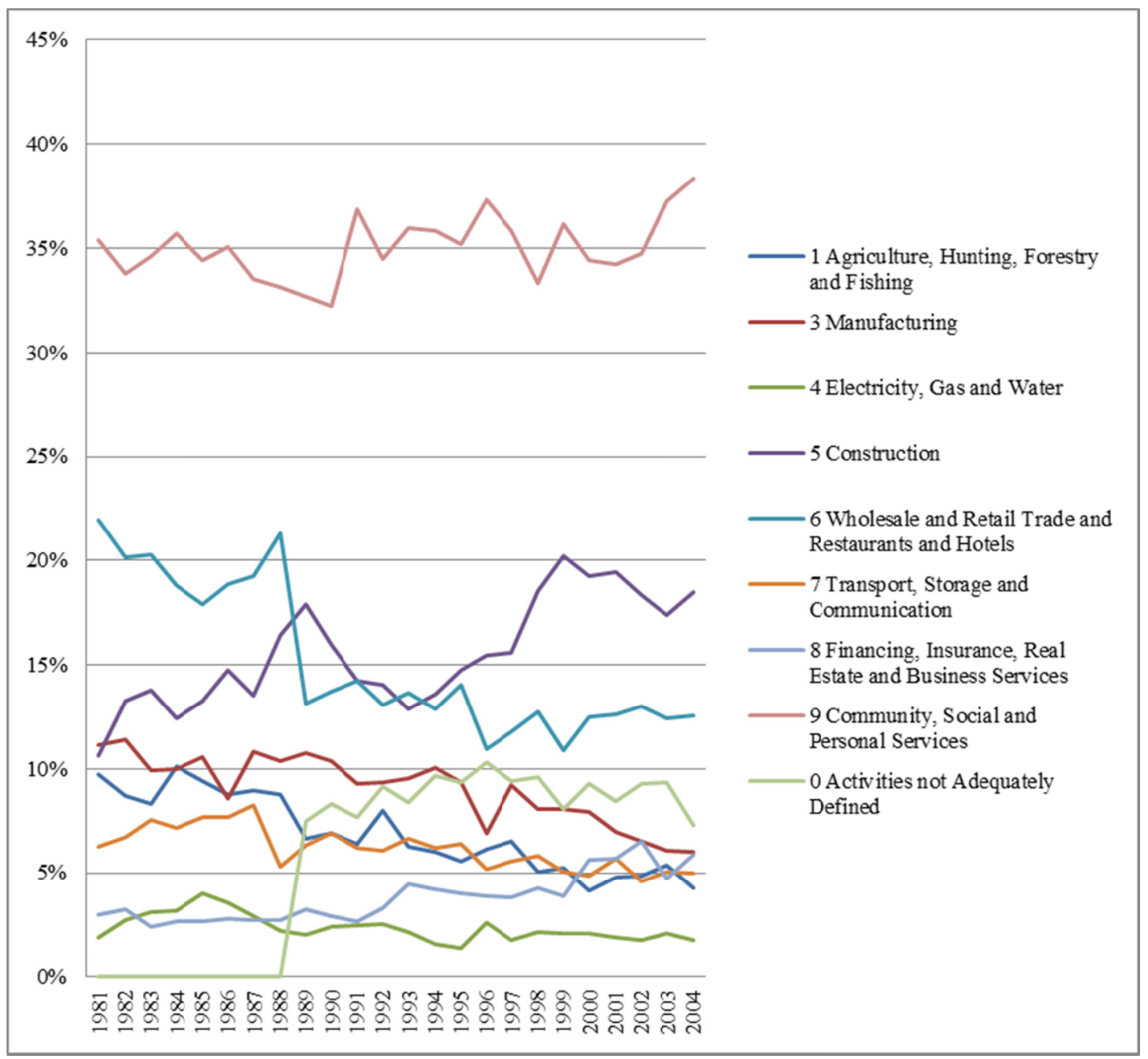

Figure 42: Male Employment by Economic Activity

Source: (International Labour Organization 2010) 


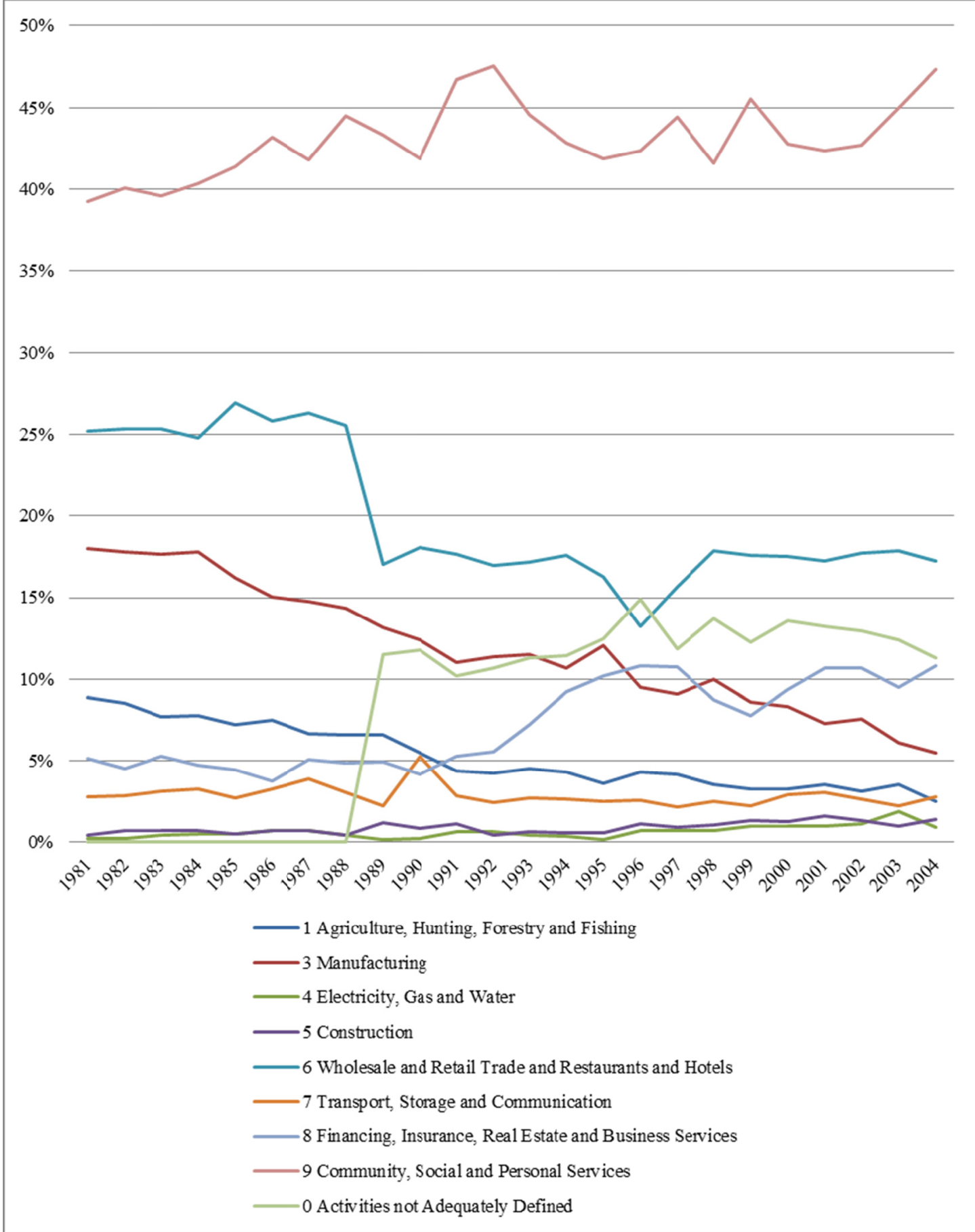

Figure 43: Female Employment by Economic Activity

Source: (International Labour Organization 2010) 


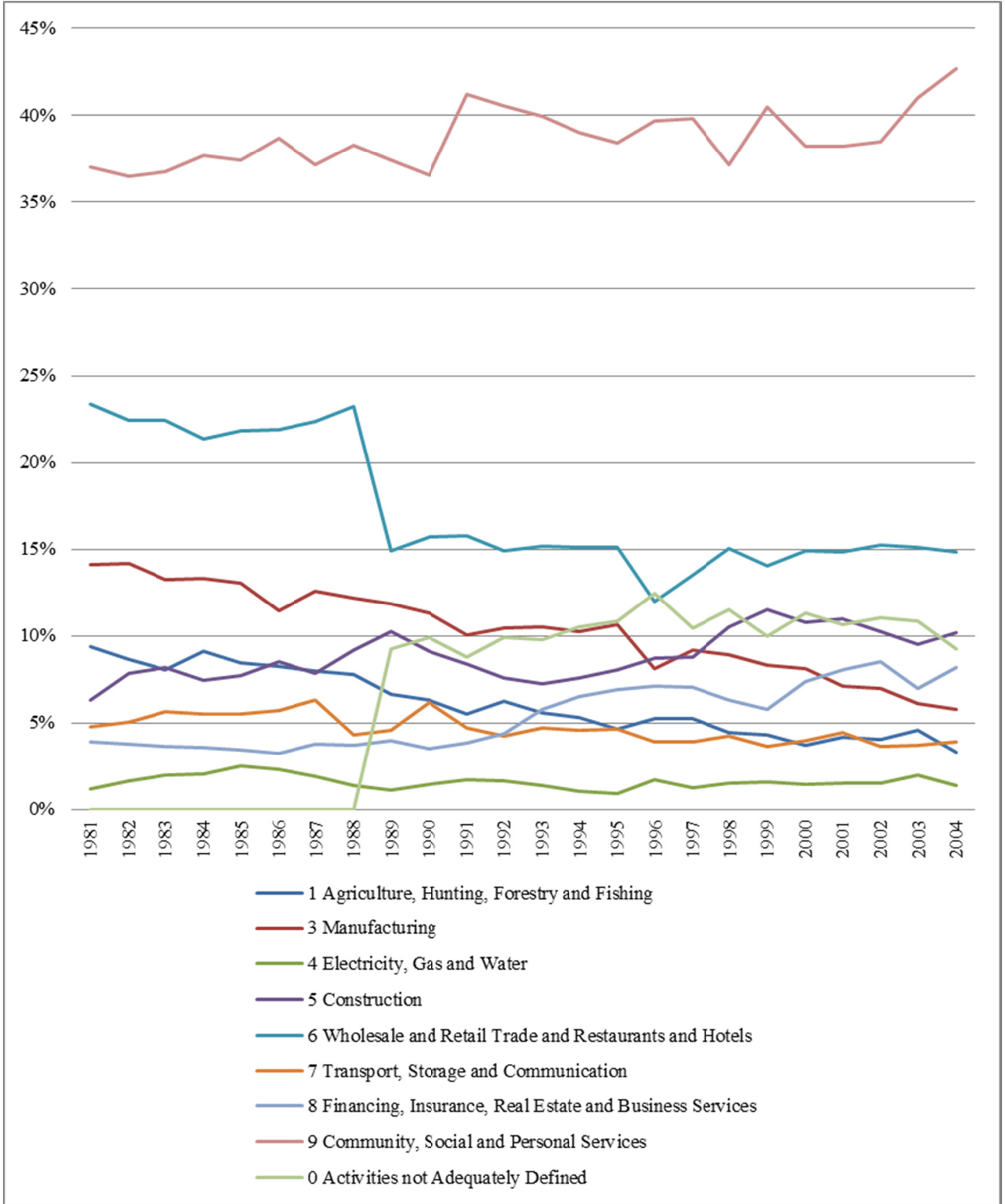

Figure 44: Employment Activity as a Share of Total Employment Source: (International Labour Organization 2010) 


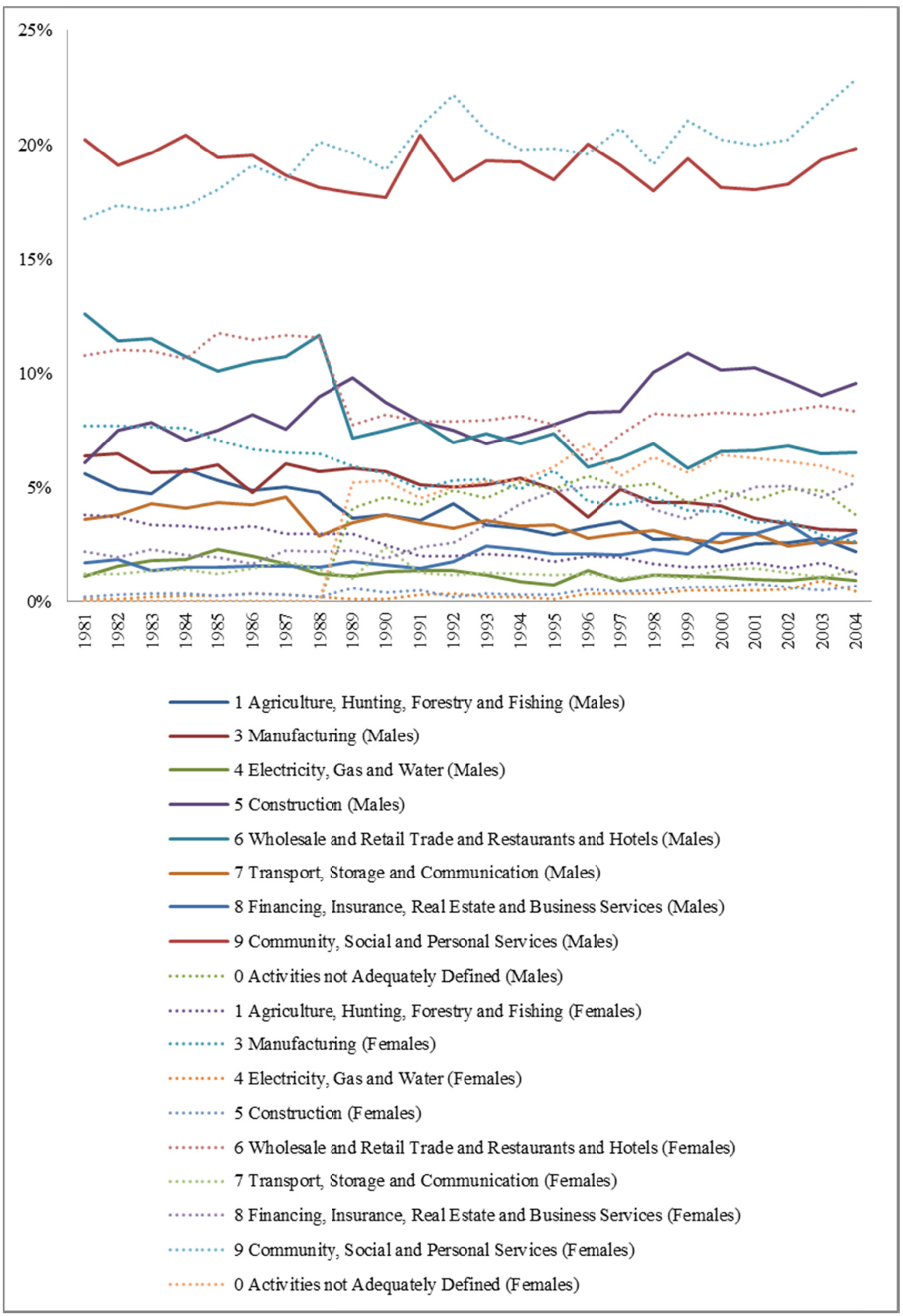

Figure 45: Employment Activity as a Share of Employment (by sex) Source: (International Labour Organization 2010) 


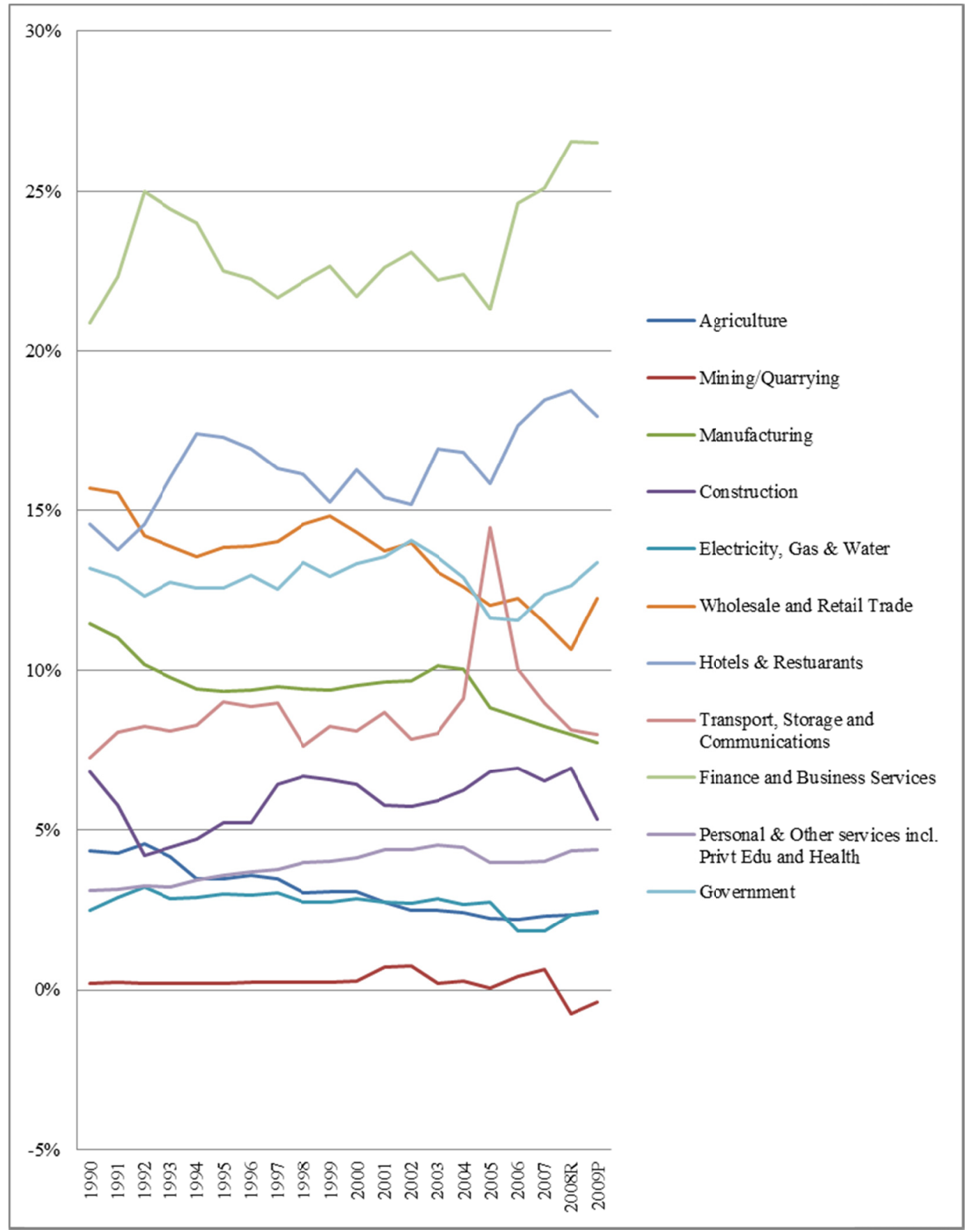

Figure 46: Economic Activity as a Share of GDP Source: (Ministry of Finance and Economic Affairs [Barbados] 2010) 
$16 \%$

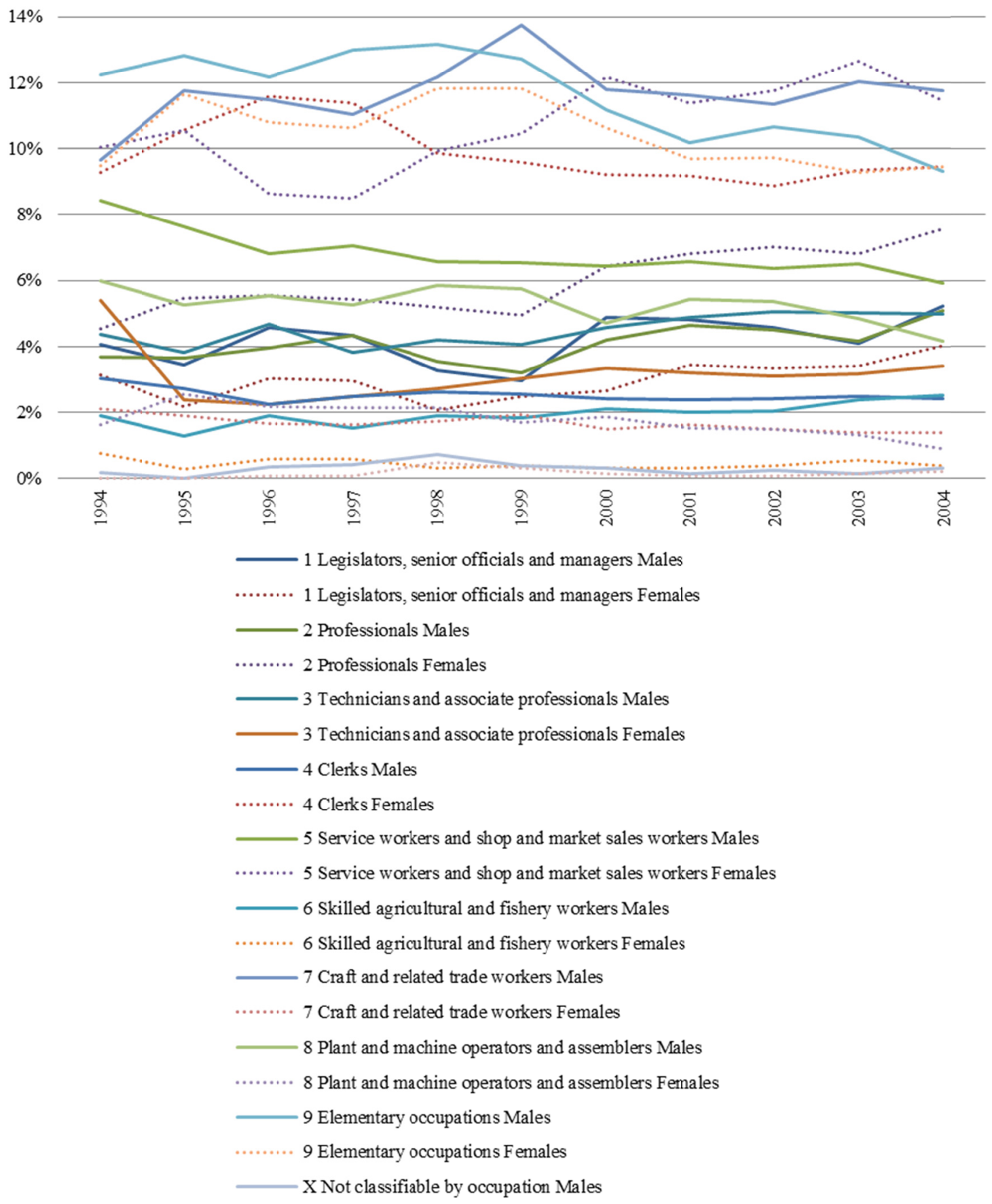

Figure 47: Proportion of Total Employment by Occupation and Sex Source: (International Labour Organization 2010) 


\section{Gender on the Political Front}

In both the international and domestic discourse the discussion on gender and politics suggested a situation in which women show mixed levels of power in decision making. As presented in Chapter II, at the international level, Barbados is often chided for its consistently low representation of females in elected government office. Indeed, this reality is not to be denied. In 2008, only 13.7 percent of parliamentary seats in Barbados were held by women (United Nations Development Programme 2010). At least since the mid-1990s women have held an average 11 percent of seats in the Lower House in Barbados (United Nations Statistical Division 2011). At the same time, not only have females comprised the majority of voter turn-out in all elections for which data are available (see Figure 48 below) but, at least since the 1981 general election, they have also tended to have higher turn-out rates than their male peers (see Figure 49).

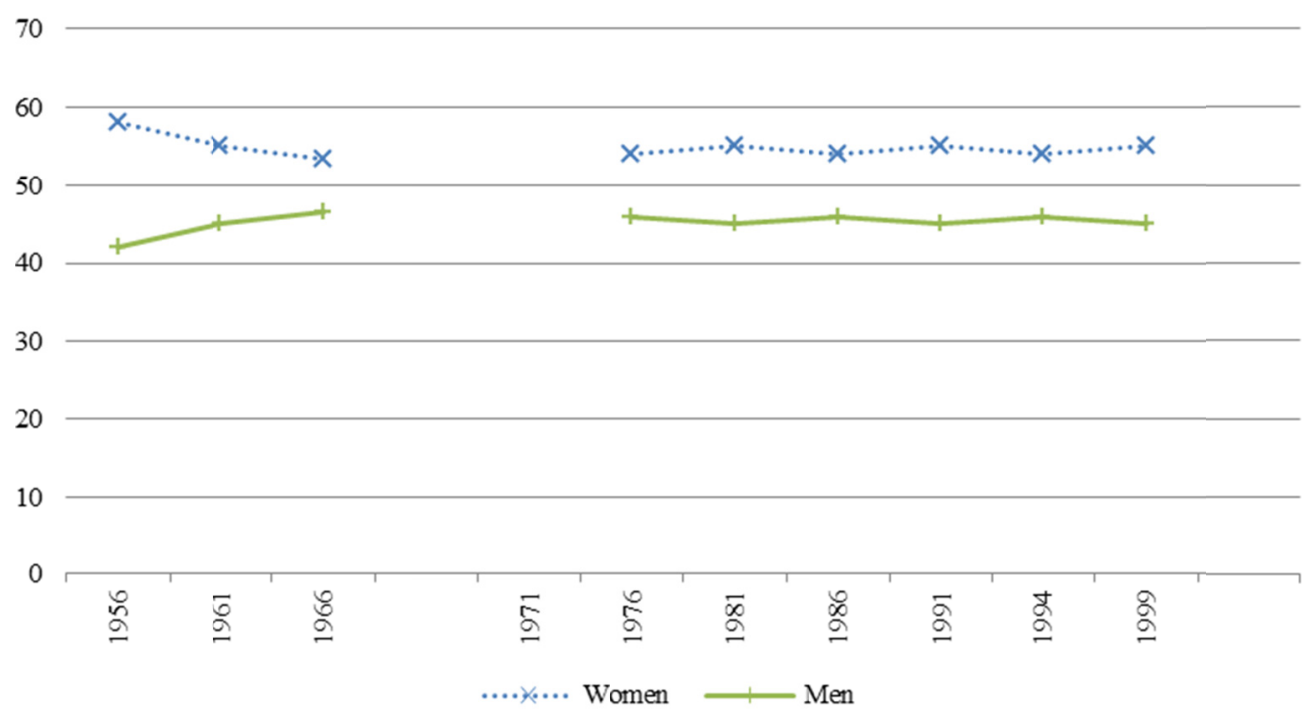

Figure 48: Voter Turnout by Sex

Source: (International Institute for Democracy and Electoral Assistance 2008) 
As such, though males remain more visible in elected office, women have not been alienated from the political process. In the last Parliamentary election in 2008, sixtyeight candidates competed for thirty Parliamentary seats. Eight women ran for office, comprising around twelve percent of the candidates. Of these, three (or 38 percent) were elected to parliament (Knowledgewalk Institute 2011). In addition, though males have continued to head parliament, women have held almost all other leading positions in the government including the ministerial portfolios for Economic Affairs, Foreign Affairs, International Business, Education and the Environment, as well as served as Attorney General, Leader of the House and Deputy Prime Minister. As outlined in the discourses presented in Chapter III, lack of visibility in elected positions would thus appear to be more a matter of psycho-social preferences, than of systemic/institutionalized blocks.

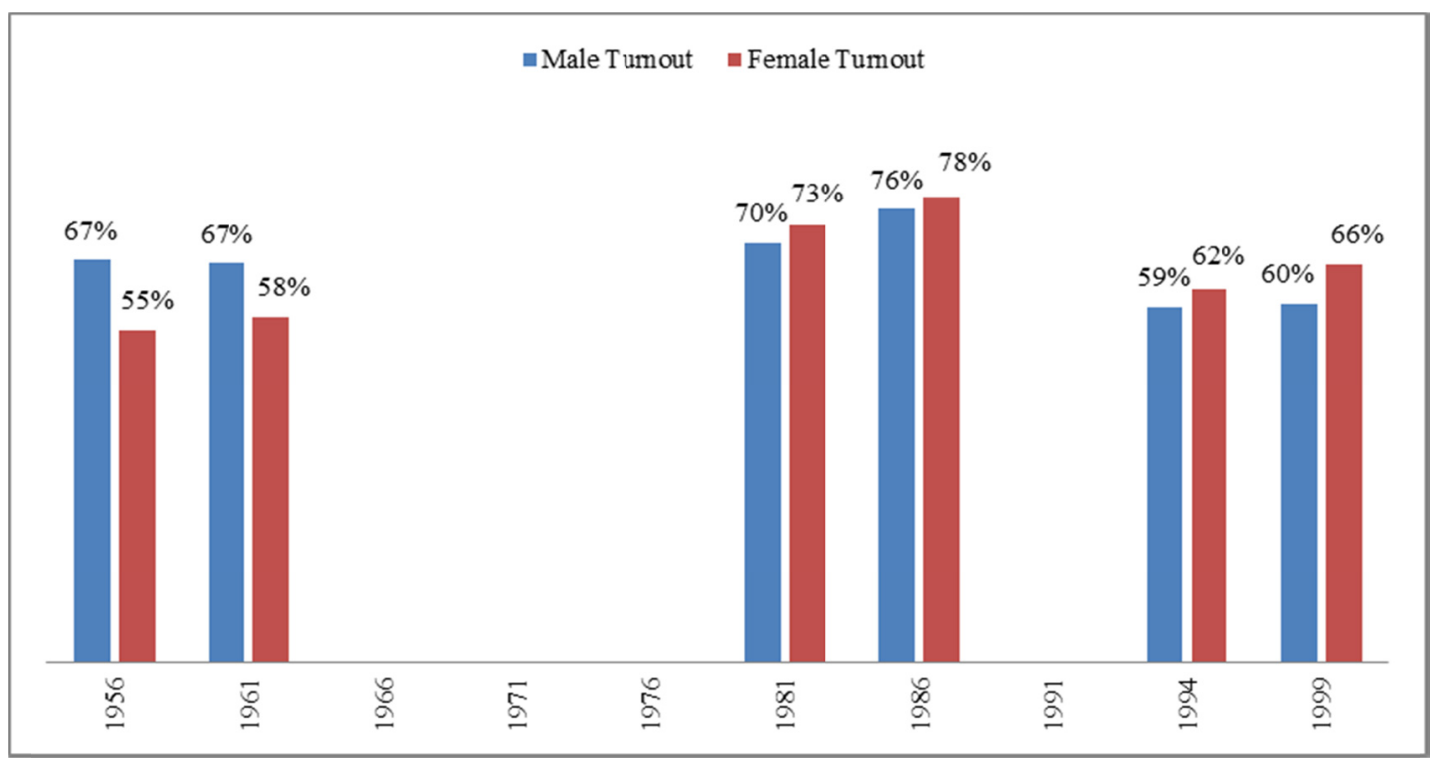

Figure 49: Voter Participation Rate by Sex

Source: (International Institute for Democracy and Electoral Assistance 2008) 


\section{Conclusion: Does the Reality of Barbadian Gender Dynamics Match the Perspectives Observed at the State and Local Levels?}

This brief analysis of the gender dynamics of social and economic status in Barbados corroborates the paradoxical assessment presented in both the state-level and local-level discourse. The socioeconomic data examined do indicate a rolling back of male performance within all sectors explored, especially in the area of education; however, the analysis of social and economic status data in Barbados does not point to the level of social and economic disempowerment and systemic marginalization of males alluded to in the domestic discourse. Though becoming increasingly outnumbered and outperformed by their female peers at all levels of education, men continue to have higher workforce participation, lower rates of unemployment, and even higher wages. They also continue to be the majority in the "seats of power," comprising the majority of Parliamentary representatives in the country. Nevertheless, the findings do challenge one of the continuing assumptions of the international paradigm, that is, that "men are better educated and trained than women who belong to the same social and national groups" (Boserup 1986). In addition, a look into some of the more qualitative factors of available SES data does point to some notable trends that would undoubtedly create the perception of female dominance across many sectors of society.

Females are increasingly outnumbering and outperforming their male counterparts in education, and are more likely to delay entry into the labor market to seek higher education. They are a greater proportion of tertiary level graduates, across all institutions, and as such, are increasing their shares in professional fields and knowledge-heavy sectors. In addition, female unemployment rates and labor force participation are 
converging with those of males. While they do make comparatively less than male employees, especially in lower-paid fields, they are increasing their concentrations in the higher income brackets. In addition, though holding a small percentage of governmental decision-making positions, those who choose to compete in the electoral processes, compete well, and female expertise has been used across diverse aspects of the government portfolio. In addition, and not to be undermined in a "first-past-the-post" electoral system, is the longstanding female control of the vote.

In Barbados, there is still a need to overcome some continued and significant challenges facing females; however, the realities of the gender dimensions of social and economic status observed do point to a major area of concern for males in Barbados: a destabilized social identity. Males in Barbados face increased international and national level concentration on female empowerment in a conflicted position. While international and national leaders and activists continue to point to the numerical evidence of female "under privilege" and suggest discrimination and the need for empowerment, males in Barbados look around them and see what appears to be a dominance of successful and highly achieving females. These perceptions are not to be undermined. As alluded in the brief introduction to social identity in Chapter I, where men see themselves in society, and the way they are seen by others, has real consequences for the way they interact with other social groups such as women, children, and figures of authority. The combined perspectives of male societal placement also have consequences for their interaction with social structures such as education and employment. In Barbados the effects of these perceptions have been most evident in the area of education, and may feed future destabilization of social structures if not adequately addressed. 


\section{LESSONS LEARNED}

My dissertation has done four things. It presented, however briefly, the international gender paradigm within the development context, outlining the major policies and indicators used in shaping and defining this paradigm and highlighting the framing of gender dynamics in this context. It then introduced a challenge to this dominant framing of gender dynamics highlighting a decades-long debate on gender dynamics within the Caribbean context, which suggests that the assumptions of the international paradigm overlooks critical elements of Caribbean social and economic structure and lived realities. It then used the case of Barbados, a Caribbean nation featuring heavily in the highlighted debate, to illustrate a framing of gender dynamics that straddles the lines of conformity and challenge to the dominant assumptions at the international level. Throughout the discussion, it has also aimed to draw out the tangencies and divergences in the framing of gender dynamics at the international, state and local levels, and the role of the international paradigm in shaping these overlaps and gaps. In so doing my work highlighted a dominant framing of gender dynamics that places males as privileged and empowered versus a discriminated and socioeconomically limited cohort of women. It showed how these assumptions, though somewhat modified, were absorbed into the feminist movement in the Caribbean, Barbados included, and used to inform state-level action focused on gender discrimination and other elements of gender dynamics. It showed also, how elements of the international frame, filtered through state action, were used to challenge this very frame, and prepare in Barbados (among other Caribbean nations) a case for righting gender discrimination and perceived gender imbalances that limit the social and economic prospects of boys and men. 


\section{The International Gender Paradigm is About Women}

Within the current international development paradigm, much emphasis is placed on the mainstreaming of gender into policy formulation and other development processes, as well as on the global achievement of gender equality. According to the Economic and Social Council of the United Nations the mainstreaming of gender into development processes is about eliminating inequality, by ensuring that the concerns and experiences of women and men are considered in the design, implementation, monitoring and evaluation of policies and programs across political, economic and societal contexts (United Nations 1997). Despite this affirmation, the focus on sex-based inequalities in international development discourse has continued to be about women, not gender. Very little emphasis is placed on men as gendered beings.

The specific needs of boys and young men, and the effect of international development on the fulfillment of these needs, have remained marginal to internationally driven discussions and interventions on gender empowerment. To argue for increased attention to the specific needs of boys and men within international development is a tough position to take in the face of the blatant biases against the equitable development of women and girls within many social contexts; however, the reality (and/or the perception there of), still remains. There are many social contexts that do not conform to the clearly oppressive patriarchal social and economic fabric portrayed by the gender analyses and policies advocated by the international development paradigm. This argument is especially forwarded in discussions of gender relations in West Africa and the Caribbean (Adesina 2011). As illustrated with the case of Barbados, there are contexts within which the relations of gender are much more convoluted, and where 
social and economic practices may at times lead to constraints and disadvantages for males, as well as females. It is important to the process of international development and the achievement of gender equality, that we acknowledge this reality, and explore such contexts, as there are many lessons that may be learnt, and new knowledge applied, in the shaping of international development goals and policies. As outlined in the presentation of the male marginalization literature in Chapter I, even with the greatest disadvantage still faced by girls and women, gender relations are changing throughout the world, especially with regard to employment, education and family life, where many men -especially boys, young men, and poor men -- are seeing increased vulnerability and marginalization (Chant and Gutman 2000).

\section{Filtering the International Gender Paradigm: Unequal Application}

The failure to recognize the heterogeneous and relational identities of males within the international gender paradigm has led to significant contradictions in both the conceptualization and implementation of the international gender paradigm in some national and local contexts. In Barbados, though the increased scrutiny of law and policy through a gendered lens brought to the fore some shortcomings in the sensitization of law and policy to the needs of women and girls, the status of women in independent Barbados has not been that of an oppressed class. Despite this, any shortcomings revealed by the reports of the government to the various treaty bodies and commissions continue to be addressed from an extreme position of "women as second-class citizens." For example the 2008 Universal Periodic Review of Barbados by the Human Rights Council of the United Nations General Assembly mentioned concern by the Committee on the Elimination of All forms of Discrimination Against Women about the "entrenched 
stereotypical attitudes and behaviour, which tended to reinforce women's inferior status in all spheres of life, and regretted that Barbados had not undertaken sustained programmes to change these social and cultural attitudes and patterns of behaviour that lead to stereotyping [emphasis added]" (Human Rights Council of the United Nations General Assembly 2008, para. 13). This 2008 report also spoke of the need to recognize that women could play other roles besides care-giving roles, and that they could be important community actors. Although these may be very true statements within the global understanding of gender relations, to apply them specifically to Barbados is somewhat mal prescribed. A large proportion of Barbadian women is and always has been significant actors in economic life. Female educational performance outweighs male performance and the opportunity for full political participation has existed for many years.

Although a situation of causality cannot be determined here, it is indeed evident that the increased scrutiny of male status from a gendered perspective paralleled the increased visibility of gender equality and women's empowerment on the social policy agenda of the Government of Barbados. The1990s saw many changes arise, in domestic law and policy, to rectify areas of discrimination against women. As outlined in Chapter II, this period saw changes to the country's citizenship policy and to various family related and individual protection statutes, modified to enhance and/or establish women's rights and non-discrimination at the domestic level. Attention to women's empowerment and gender equality by the Barbadian government were not new to the period, but what appears to have been new, was the high visibility of these changes in public forums. As reported to the Committee on the Elimination of Discrimination Against Women in 1994, 
the Government had stepped up its use of public forums such as newspapers and radiocall-in programs to heighten public awareness on the need for gender equality and the empowerment of women through the elimination of discriminatory policy, practice and attitudes. Barbados had become increasingly active on the issue of gender equality at the international level at this time, working to submit back-logged reports and ensuring representation within international bodies addressing these issues.

The discussion presented in my dissertation brought to light a bias in the application of the measures of gender equality to male and female subjects across all spatial levels. The discussion on gender in Barbados, and the related policy changes at the national level, focused on six of the areas of attention outlined by the Convention on the Elimination of Discrimination Against Women: the participation of women in public and political life, access to and experience of education, access to and treatment in employment, women's economic and social life, equality before the law, and equality in marriage and family life. In three of these areas - access to and experience in education, equality before the law, and equality in marriage and family life - men appear to be facing greater challenge than their female counterparts.

\section{Male Marginality: Fact or Fiction?}

The "women-as-victims" approach dominant in the international paradigm would evoke in males a need to defend themselves as it casts their social identity in a negative light. However, in the case presented the arguments go beyond mere defensive backlash. While men do not exist at the margins of Barbadian society, they appear to have a much more limited social identity than their female counterparts. As such, though the numbers show them to be the economically and politically dominant group, they do not wield the 
same measure of social power as do their female counterparts. In other words, both as individuals, and as a group, women appear to have fewer restrictions applied to the ways and means by which they experience their day-to-day lives. In addition, women are not marginal in the economic and political life of Barbados. In fact, despite their less dominant political and economic reality, the analysis here showed women to be more visible in public life than their male counterparts, especially within the work force. Though women tend to be the greater proportion of the poor and the unemployed, the margins are small, and this is juxtaposed to higher concentrations of women in the upper echelons of income, as well as a dominant female political class. In addition, as women become increasingly dominant in secondary and tertiary education, the margins of economic life are shrinking.

Within the Barbadian context, these counterfactuals shaping women's lives interact with a matrifocal social structure, and increased political attention to women's advancement to form a shrinking psychosocial box in which the majority of Barbadian males find themselves sitting.

\section{Leveraging the Lessons Learned}

As my work's exploration of Barbadian gender dynamics reveals, when the international gender paradigm met with Barbadian society it found a place in which the freedom to work, the ability to support children financially and emotionally, and to be independent (not dependent on a male partner), were already integral to what it means to be a woman (Mohammed and Perkins 1999), but where patriarchal notions still fed ideals on what roles men ought to play in society and the family. It met with a society in which many, if not most, children - males and females alike - are raised in households where a 
female is in charge, both domestically and economically. It met with a society in which classrooms are dominated by females both intellectually and logistically. It met with this society, and it unhinged or at least problematized the one legitimating element of a dominant male social identity: male privilege.

The paradigm however, has problematized this element of the gender dynamic without creating space for addressing relations of gender in which male privilege is waning, and masculine social identity is no longer the standard by which all else is measured. As such, there is no guidance for negotiating interactions between males and females that are not about pitting the failures and successes of one group against that of the other, nor for recognizing when perspectives of male gender place men and boys at a disadvantage.

As seen with the Barbados case, the failure to address male gender perspectives in a relational manner has led to a diminishing of the significance to society of the psychosocial challenges that men are increasingly facing, as former socioeconomic norms quickly dissolve. In the Barbados case, challenges that men faced in education and employment have been framed as resulting from their own attitudes and not warranting system-level intervention. On the other hand issues of low political representation and labor force segregation for women, though recognized as more engrained in attitudes than access, have met with suggestions for state-level intervention through awareness raising, and state-supported re-skilling.

As such, to continue to approach gender dynamics and the achievement of gender equality within the dominant frame of the international gender paradigm, that is, to look at men and women in competing positions, and measure the roles against each other, is at 
this point a cul-de-sac to effecting just gender dynamics in any society. "A global women's movement - whatever the situation of at local levels - must show that its goal is not to build the women's movement per se but to contribute to strengthening the movement for global justice" (Antrobus 2004, 143). The male side of the equation must be fully understood and figured into any analysis of the equality of social and economic relations (White 1997). As such, I argue for equal recognition of the effects of gender dynamics on the lives of women and men and a transformative framing of social relations that allows males and females to assume a shared social identity, seeing themselves as members of a singular group working towards a shared goal of an equitable society.

The complex of gender relations presented in the case of Barbados was once seen as an anomalous structure - an outlier in the understanding of social relations across the globe (Momsen 1993). However, as the combination of globalization and growing women's empowerment continues to shift women's "place" and challenge the dominance of patriarchy in other societies around the world (Chant and Gutman 2000, Domosh and Seager 2001), an understanding of how gender defines itself in Barbados and other similar social contexts will prove invaluable. 


\section{WORKS CITED}

Abassi, Jennifer, and Sheryl L. Lutjens. 2002.Reading Women in Latin America and the Caribbean: The Political Economy of Gender. Lanham; Boulder, Colorado; New York; Oxford, UK: Rowman and Littlefeld.

Adésínà, 'Jìmí O. 2010. "Re-appropriating Matrifocality: Endogeneity and African Gender Scholarship.” African Sociological Review, 14 no. 1: 2-19

Andaiye. 2003."Smoke and Mirrors: The Illusion of CARICOM Women's Growing Economic Empowerment, Post- Beijing." In Gender Equality in the Caribbean: Reality or Illusion? edited by gemma Tang Nain and Barbara Bailey Kingston, 73107. Jamaica: Ian Randle (in collaboration with the CARICOM Secretariat and UNIFEM.

Antrobus, Peggy. 2004. The Global Women's Movement: Origins Issues and Strategies. London: Zed Books

Atwell, Carlos. 2007. "Women still Being Sidelined." Daily Nation, November 2: 26.

Banfield, Jackie. 1995. "25 Years of Flying the Banner." Daily Nation, August 23: 1C.

Barbados Bureau of Gender Affairs. 2004. "Response to Beijing 10-year Review." United Nations Division for the Advancement of Women. Accessed September 17, 2010. http://www.un.org/womenwatch/daw/Review/responses/BARBADOSEnglish.pdf.

Barbados Community College. 2011. Programmes of Study.Accessed July 4, 2011.http://www.bcc.edu.bb/ProspectiveStudents/ProgrammesOfStudy/Associate DegreeProgrammes.aspx\#MajorInArts.

Barbados Ministry of Education. 2000. Education in Barbados Information Handbook. Accessed September 10, 2011. http://www.mes.gov.bb/UserFiles/File/Education_in_Barbados.pdf.

—. n.d."Compilation of Statistics 1990-2009" (Unpublished Data)

Barbados. 2008. Statement by John Holllingsworth, Director Bureau of Gender Affairs, Barbados at the Fifty-Second Meeting of the Commission on the Status of Women. New York: Permanent Mission of Barbados to the United Nations.

Barriteau, Eudine. 2001. The Political Economy of Gender in the Twentieth Century Caribbean. Hampshire, UK: Palgrave.

Barrow, Christine. 1998. Caribbean Portraits: Essays on Gender Ideologies and Identities. Kingston, Jamaica: Ian Randle Publishers, in association with the Centre for Gender and Development Studies, the University of the West Indies. 
Bellony, Annelle, Alejandro Hoyos, and Hugo Nupo. 2010. "Gender Earnings Gaps in the Caribbean: Evidence from Barbados and Jamaica." IDB Working Paper Series No. IDB-WP-210.August. Washington, D.C.: Inter-American Development Bank (Department of Research and Chief Economist).

Benetti, Raffaello. 2003. Survival of Weak Countries in the Face of Globalization: Puerto Rico and the Caribbean. San Juan: Editorial de la Universidad de Puerto Rico.

Benton, Marc, and P. Jean Frazier. 1976. "The Agenda Setting Function of the Mass Media at Three Levels of "Information Holding"." Communication Research 3, no. 3: 261-274.

Best, Robert. 1997. "Solutions for Young Males." Daily Nation, September 30: 6.

Best, Tony. 2007. "Prescod - More Women Sliding into Poverty." Daily Nation, March 21: 6 .

—. 2008. "Some More Equal..." Sunday Sun, March 30: 24A.

Blackman, John. 1997a. "Girls Always Top Performers." Sunday Sun, October 26: 24A.

—. 1997b. "Labour Market Law Biased Against Women." Sunday Sun, November 9: 12A.

—. 2003. "Taking Our Women for Granted." Sunday Sun, January 26: 8A.

Bolles, Lynn. 1998. "Working on Equality: Commonwealth Caribbean Trade Union Leaders." In Caribbean Portraits: Essays on Gender Ideologies and Identities, edited by Christine Barrow. Kingston, Jamaica: Ian Randle.

Boserup, Esther. 1986. Woman's Role in Economic Development. Gower Edition. Hants, England; Vermont, USA: Gower in Association with London School of Economis and Political Science.

Brandford, Albert. 2007. "Women Moving Up." Daily Nation, August 17: 48.

Caesar, Richard. 2006. "MESA Now Wants to Help Gays." Sunday Sun, April 2: 5A.

Central Bank of Barbados. 2010. The Barbados Economy in 2009 and Prospects for 2010. Bridgetown, Barbados: Central Bank of Barbados.

Chaffee, Steven, and Stacey Frank. 1996. "How Americans Get Political Information: Print versus Broadcast News." Annals of the American Society of Political and Social Science 546, no. The Media and Politics (July): 58-48.

Chant, Sylvia, and Matthew Gutman. 2000. Mainstreaming Men into Gender and Development. London: Oxfam. 
Chant, Sylvia. 2001. "Men in Crisis? Reflections on Masculinities, Work and Family in North-West Costa Rica." In Men at Work: Labour, Masculinities, Development, edited by Cecile Jackson. London; Portland, OR: Frank Cass.

Charlton, Sue Ellen.1997. "Development as History and Process." In The Women, Gender and Development Reader, edited by Nalini Visvanathan, Lynn Duggan, Laurie Nisonoff and Nan Wiegersma. London, UK; New Jersey, USA: Zed Books.

Cohen, Bernard C. 1963. The Press and Foreign Policy. Princeton: Princeton University Press.

Committee on the Elimination of Discrimination against Women. 1992a. Consideration of Reports Submitted by States Parties Under Article 18 of the Convention:

Second and Third Periodic Review of the States Parties Barbados(CEDAW/C/BAR/2-3). New York: United Nations.

—. 1992b. Summary Record of the 190th Meeting Held at Headquarters, New York on Monday, 20 January 1992. New York: United Nations.

—. 1992c. Summary Record of the 194th Meeting, Held at Headquarters, New York on Thursday, 23 January 1992. New York: United Nations.

- 1993. Report of Eleventh Session of the Committee on the Elimination of Discrimintaion against Women (A/47/38). New York: United Nations.

—. 1994. Summary Record of the 245th Meeting (CEDAW/C/SR.245). New York: United Nations.

-. 2000. Consideration of Reports Submitted by States Parties Under Article 18 of the Convention on the Elimination of All Forms of Discrimination Against Women: Fourth Periodic Report of the State Parties - Barbados, $C E D A W / C / B a r / 4$.NewYork: United Nations

-. 2002. Reports Provided by the Specialized Agencies on the Implementation of the Convention in Areas Falling Within the Scope of Their Activies: Note by the Secretary-General, Addendum - International Labour Organization (CEDAW/C/2002/EXC/3/Add.4). New York: United Nations.

- 2003. Summary Record of the 579th Meeting: Consideration of Reports Submitted by States Parties Under Article 18 of the Convention on the Elimination of All Forms of Discrimination against Women, Fourth Periodic Report of Barbados. New York: United Nations.

—. 2010.Status of Submission of Reports by States Parties Under Article 18 of the Convention: Report of the Secretary-General (CEDAW/C/2010/46/2). Geneva: United Nations. 
Committee on the Rights of the Child. 1999. Summary Record of the 536th Meeting: Consideration of the Reports of States Parties: Initial Report of Barbados (CRC/C/SR.536). Geneva: United Nations.

Commonwealth Secretariat. 2000. "Report of the 6th Annual Meeting of the Commonwealth Ministers Responsible for Women's Affairs, New Delhi, 17-19 April 2000." Commonwealth Secretariat. Accessed July 30, 2006. www.thecommonwealth.org.

Connell, Robert W. 2000. The Men and the Boys. Cambridge: Polity.

Constitution of Barbados.L.R.O 2000.Accessed October 17, 2010.http://www.lexadin.nl/wlg/legis/nofr/oeur/lxwebar.htm.

Crichlow, Harold. 2000. "Co-ed Here to Stay." Daily Nation, March 29: 8A.

Da Silva, Frank. 2010. "Women - No. 1 Gender." Nationnews.com. September 17. Accessed September 17, 2010.

http://www.nationnews.com/index.php/articles/view/guest-column-women-no.-1gender/ .

Daily Nation.2002a. "Attracting More Male Teachers." July 22: 8.

—. 2002b. "Men's Forum: Support for Gender Parity." October 9: 22A.

—. 2003. "'Ease Up' on the Boys." February 27: 5.

Daniel, Patrice. 2006. "Give Males a Chance." Daily Nation, December 20: 8A.

David, Michael. 2009. "Need for Affirmative Action." Sunday Sun, March 29: 9A.

De Alburquerque, Klaus, and Sam Ruark. 1998. "'Men Day Done': Are Women Really Ascendant in the Caribbean." In Caribbean Portraits: Essays on Gender Ideologies and Identities, edited by Christine Barrow. Kingston, Jamaica: Ian Randle.

Des Champs, Jean Claude. 1982. "Social Identity and Relations of Power between Groups." In Social Identity and Intergroup Relations, edited by Henri Tajfel, 8598. New York: Cambridge.

Dobson, James (submitted by the Men's Educational Support Association). 2005.

"Bringing up Boys (Part 2)." Daily Nation, March 23: 17A.

Domosh, Mona, and Joni Seager. 2001. Putting Women in Place: Feminist Geographers Make Sense of the World. New York: Guilford Press. 
Drummond-Hoyos, Ella. 2003. "Working With The Female Factor." Daily Nation, May 12: 9.

ECLAC-Caribbean. 2001. An Analysis of Economic and Social Development in Barbados: A Model for Small Island Development States (LC/CAR/G.652).Portof-Spain, Trinidad: ECLAC-Caribbean

- 2010. Caribbean Synthesis Review and Appraisal Report in the Context of the 15th Anniversary of the Adoption of the Beijing Declaration and Plan of Action (LC/CAR/L.259). Port-of-Spain, Trinidad: ECLAC-Caribbean.

Economic and Social Council Commission on the Status of Women. 2005. Measures Taken and Progress Achieved in the Follow-up to and Implementation of the Fourth World Conference on Women and to the Twenty-third Special Session of the General Assembly (E/CN.6/2006/2). New York: United Nations.

Edward, Geralyn. 2005. "Glass Ceiling Keeping Them Out." Business Authority, April 25: 11 .

Ejimofor, Patience. 1998. "Laws Ahead of Attitudes Toward Women." Daily Nation, December 16: 17A.

—. 2003a. "Griffith-Watson - No Harm in Co-ed." Daily Nation, April 7: 2.

—. 2003b. "Missus More Than Massa." Sunday Sun, April 13: 16A.

—. 2004. "Not Just For Women!" Daily Nation, February 26: 30.

Ellis, Patricia. 2003. Women, Gender and Development in the Caribbean. Kingston, Jamaica: Ian Randle.

Entman, R. 1993. "Framing: Toward Clarification of a Fractured Paradigm." Journal of Communication 43, no. 4: 51-58.

Epstein, Debbie, Janette Elwood, Valerie Hey, and Janet Maw, Eds. 1998.Failing Boys? Issues in Gender and Achievement. Buckingham, UK: Open University Press.

Family Talk. 2011. About Family Talk.Accessed February 27, 2011. www.myfamilytalk.com.

Farley, Matthew. 2008. "The Trouble with Black Boys." Sunday Sun, October 5: 8A.

Focus on the Family. 2011.About Focus on the Family.Accessed February 27, 2011. www.focusonthefamily.com. 
Foster, Victoria, Michael Kimmel and Christine Skelton. 2001. In What About the Boys? Issues of Masculinity in Schools, edited by Wane Martino and Bob Meyen. Buckingham: Open University Press.

Gaye, Amie, Jeni Klugman, Milorad Kovacevic, Sarah Twigg, and Eduardo Zambrano. 2010. "Measuring Key Disparities in Human Development: the Gender Inequality Index (HDR Research Paper 2010/46)." United Nations Development Programme Human Development Reports Research Papers, December.

Gibbons, Wade. 2004. "Sir Keith - Gender Not the Problem." Sunday Sun, May 30: 32A.

Griffith, Derek L. V. 2004. "Punishment No Answer." Daily Nation, February 19: 10.

Gruenfeld, Deborah H., M. Ena Inesi, Joe C. Magee, and Adam D. Galinsky. 2008. "Power and the Objectification of Social Targets." Journal of Personality and Social Psychology 95, no. 1 (July): 111-127.

Hardt, D. Brent. 2009. "It's Violence Against Us All." Daily Nation, December 1: 9.

Haynes, Carmel. 2003. "Gender a 'Man Thing' Too." Sunday Sun, September 21: 12A.

Headley, Nicholas. 1995. "Statistics Say a Lot about Boys in Crisis." Daily Nation, November 6: 14A.

—. 1996. "Our Boys are Being Mauled." Weekend Nation, April 19: 11.

Hinds, Cobin. 1998. "The Endangered Male." Weekend Nation, October 16: 8.

Ho, Christine. 2002. "Caribbean Transnationalism as a Gendered Process." In Reading Women in Latin America and the Caribbean: The Political Economy of Gender, edited by Jennifer Abassi and Sheryl L. Lutjens, 112-128. Lanham; Boulder, Colorado; New York, NY; Oxford, UK: Rowman and Littlefield.

Holder, Kenya. 2007. “Where Are the Ball Girls?” Daily Nation, March 19.

Human Rights Committee of the International Covenant on Civil and Political Rights. 2006. Consideration of Reports Submitted by States Parties Under Article 40 of the Covenant: Third Periodic Reports of the States Parties Due on 11 April 1991 Barbados (CCPR/C/BRB/3). Geneva: United Nations.

Human Rights Council of the United Nations General Assembly. 2008a. Compilation Prepared by the Office of the High Commissioner for Human Rights, in Accordance with Paragraph 15(b) of the Annex to Human Rights Council Resolution 5/1 (A/HRC/WG.6/3/BRB/2). Geneva: United Nations. 
-. 2008b. National Report Submitted in Accordance with Paragraph 15(a) of the Annex to Human Rights Council resolution 5/1 * - Barbados

$(A / H R C / W G .6 / 3 / B R B / 1)$. Geneva: United Nations.

International Human Rights Instruments. 1995. Core Document Forming Report of States Parties - Barbados (HRI/CORE/1/Add.64). United Nations.

International Institute for Democracy and Electoral Assistance. 2008. "Voter Turnout By Gender and Country: Barbados." April.

http://www.idea.int/gender/vt_by_country.cfm\#barbados (accessed August 10, 2011).

International Labour Organization. 2004. "Summary of Major Groups." ISCO: International Standard Classification of Occupations. September 15. http://www.ilo.org/public/english/bureau/stat/isco/isco88/publ4.htm (accessed July 30, 2011).

—. 2010.Main Statistics [Annual]. laborsta.ilo.org (accessed July 30, 2011).

-. 2009. Key Indicators of the Labour Market. 6th Edition. Computer Software and File. Geneva: International Labour Office.

International Monetary Fund. 2011.World Economic Outlook Database (September 20). Accessed November 1, 2011.http://www.imf.org/external/pubs/ft/weo/2011/02/weodata/index.aspx.

Jackman, Oliver. 1996. "The Oliver Jackman Column: The Feminising of Bim." Sunday Sun, September 29: 6A.

Jackson, S. 1998. "Feminist Social Theory". In Contemporary Feminist Theories, edited by Stevi Jackson and Sheryl Jones. New York: New York University Press.

Kimmel, Michael S. 1987. The Contemporary Crisis of Masculinity in Historical Perspective." In The Making of Masculinities: The New Men's Studies, edited by Harry Brod. Boson: Allen \&Unwin.

Knowledgewalk Institute. 2011. "Vote Barbados 2008." Caribbean Elections:

Barbados.Accessed Auguts 10, 2011. http://www.caribbeanelections.com/barbados/results/default.asp.

Levine, Ruth, Cynthia Lloyd, Margaret Greene, and Caren Grown. 2008. Girls Count: A Global Investment and Action Agenda. Washington, D.C.: Center for Global Development.

Lewis, Wayne. 1993. "Women Taking over Lead Roles." Nation Business, October 29: 10. 
Lippman, Walter. 1922. Public Opinion. New York: Macmillan.

Lynch-Foster, Amanda. 2004a. "Bajans Eager to Adopt." Daily Nation, May 11: 3.

—. 2004b. "Women Making Presence Felt." Daily Nation, June 16.

Maingot, Anthony P., Wilfredo Lozano. 2005.The United States and the Caribbean:

Transforming Hegemony and Sovereignty. New York: Routledge.

Mason, Cara. 2000. "Helping Boys Become Educated Men in Barbados." In World Education Forum 2000, edited by Inter Press Service. Paris: UNESCO. http://www.unesco.org/education/wef/en-news/barbados.shtm (accessed July 4, 2011).

McCarthy, Charmaine. 2003. "Paternity Leave Plea." Daily Nation, March 13: 5.

McCombs, Maxwell E, and Donald L. Shaw. 1972. "The Agenda-Setting Function of Mass Media." Public Opinion Quarterly 36, no. 2: 176-187.

McDowell, Linda. 2003.Redundant Masculinities? Employment Change and White Working Class Youth. Malden, MA: Blackwell Publishers.

McQuail, Denis, and Sven Windahl. 1993.Communication Models: For the Study of Mass Communication. 2nd Edition. London and New York: Longman.

Men's Educational Support Association. 2001. "Mens Forum: Striking a Gender Balance." Daily Nation, November 14: 20A.

—. 2002. "Flaws in Co-ed System." Daily Nation, November 13: 21A.

Miller, Errol.1991.Men at Risk. Kingston: Jamaica Publishing House Limited.

—. 1994.The Marginalization of the Black Male: Insights from the Development of the Teaching Profession. 2nd Edition. Barbados; Jamaica; Trinidad \& Tobago: Canoe Press (First published in 1986 by the Institute of Social and Economic Research, Mona).

Ministry of Finance and Economic Affairs [Barbados]. 2010.Barbados SocioEconomic Data: 2010 Pocket Statistics. Warrens, St. Michael: Ministry of Finance and Economic Affairs, Research and Planning Unit.

Mohammed, Patricia. 2004. "Engendering Masculinity: Cross Cultural Caribbean Research Inititiatives. [Paper presented to the Latin American Studies Association Annual Conference, March 2000]." In Interrogating Caribbean Masculinity: Theoretical and Empirical Analyses, edited by Rhoda Reddock. Mona, Jamaica; Cavehill, Barbados; St. Augustine, Trinidad \& Tobago: University of the West Indies Press. 
Mohammed, Patricia, and Althea Perkins. 1999. The Paradox of Motherhood among Women of Barbados, St. Lucia and Dominica. Kingston, Jamaica: Canoe Press, University of the West Indies.

Momsen, Janet H. 1993. "Introduction." In Women and Change in the Caribbean, edited by Janet H. Momsen. Kingston: Ian Randle: 1-12

Morgan, Dawn. 1998a. "Girls Not Forcing Boys Into Failure." Weekend Nation, September 28: 29.

—. 1998b. "Feminsim - Nothing New." Weekend Nation, December 24: 21.

—. 1999a. "Gender 'Erases Women'." Sun on Saturday, June 5: 20.

—. 1999b. "Single Mums 'Since Slavery'." Sunday Sun, June 13: 15A.

—. 2000. "Slow Progress on Gender Bureau." Sunday Sun, November 26,: 15B.

Morrissey, Marietta. 1998. "Explaining the Caribbean Family: Gender Ideologies and Gender Relations." In Caribbean Portraits: Essays on Gender Ideologies and Identities, edited by Christine Barrow, 78-90. Kingston, Jamaica: Ian Randle Publishers, in association with the Centre for Gender and Development Studies, the University of the West Indies.

Morton, Tom. 1997, Altered Mates: The Man Question. New South Wales, Australia: Allen \&Unwin.

Mullings, Beverley. 1998. "Jamaica's Information Processing Services: Neoliberal Niche or Structural Limitation?" In Globalization and Neoliberalism: The Caribbean Context, edited by Thomas Klak. Lanham, 135-154. Boulder; New York; Oxford: Rowman \& Littlefield.

Nurse, Keith. 2004. "Masculinities in Transition: Gender and the Global Problematique." In Interrogating Caribbean Masculinities: Theoretical and Empirical Analyses, edited by Rhoda Rheddock, 3-37.Jamaica; Barbados; Trinidad and Tobago: University of the West Indies Press

Pantin, Denis A. 2003. "The Economies of the Caribbean." In Understanding the Contemporary Caribbean, edited by Richard S. Hillman and Thomas J.

D'Agostino. Boulder, Colorado; London, UK: Lynne Reiner.

Parry, Odette. 1996. "In One Ear and Out the Other: Unmasking Masculinities in the Caribbean Class Room." Sociological Research Online 1, no.2

Quinlan, Robert J. 2006. "Gender and Risk in a Matrifocal Caribbean Community: A View from Behavioral Ecology." American Anthropologist, 108 no. 3: 464-479 
Reddock, Rhoda. 1999. "Feminism and Feminist Thought: A Historical Overview." In Gender in Caribbean Development: Papers Presented at the Inaugural Seminar of the University of the West Indies, Women and Development Studies Project, edited by Patricia Mohammed and Catherine Shepherd, 53-73. Cavehill, Barbados: Canoe Press. (First Published 1988 by The Women and Development studies Project.)

Reese, Stephen D. 2008. "Prologue - Framing Public Life: A Bridging Model for Media Research." In Framing Public Life: Perspectives on Media and our Understanding of the Social World, edited by Stephen D. Reese, Oscar H. Gandy Jr. and August E. Grant, 7-32. Mahwah, NJ: Lawrence Erlbaum Associates.

Russell, Stacey. 2008a. "Women Striking out on Their Own." Business Authority, March 17, 2008: 23.

—. 2008b"BEC Wants More Boardroom Doors Open to Women." Business Authority, March 24: 12.

Samuel Jackman Prescod Polytechnic. 2011. Samuel Jackman Prescod

Polytechnic. Accessed July 4, 2011.

http://www2.sjpp.edu.bb/index.php?option=com_content\&task=view\&id=56\&Ite $\operatorname{mid}=50$.

Scott, J. 1998. Gender and the Politics of History (Revised Edition). New York:

Columbia University Press. Quoted in Rereading Women in Latin America and the Caribbean: The Political Economy of Gender, edited by J. Abassi\& S. Lutjens, 2002.Lanham, MD: Rowman\& Littlefield Publishers, Inc.

Sealy, Donna. 2003. "Liz - Train Women for Men's Jobs." Daily Nation, March 24: 22.

—. 2004. "Maintenance Act Is 'Criminal'." Daily Nation, April 21: 5A.

Senior, Olive. 1991. Working Miracles: Women's Lives in the English-Speaking Caribbean. Cave Hill, Barbados: Institute of Social and Economic Research in Association with James Currey Ltd. and Indiana University Press

Simmons, Peter. 2009. "Ladies on the Move." Sunday Sun, November 15: 8A.

Solien de González, Nanciel. 1965. "The Consanguineal Household and Matrifocality." American Anthropologist, New Series, 67, no. 6: 1541-1549. Blackwell Publishing on behalf of the American Anthropological Association.

Smith, Raymond T. 1956. The Negro Family in British Guiana: Family Structure and Social Status in the Villages. London: Routledge\& Paul.

Springer, Michelle. 2009. "Caribbean 'Not Safe for Women.'" Sunday Sun, March 8: $23 \mathrm{~A}$. 
Sunday Sun.1998. "Caribbean Boys in Crisis." December 20: 20.

-.2003. "Burdens of the Caribbean Man." November 23: 44A.

Tafari, Ikael. 2005. "African Crossroads: Black Masculinity." Daily Nation, September 5: 8.

The Barbados Advocate.2009. "Adoption Plea -Boys Need Homes Too." October 2. Accessed September 18, 2011. www.barbadosadvocate.com/newsitem.asp?more=local\&NewsID $=6497$.

The Nation Publishing Co. Limited. 2005. "The Nation's Market Reach." The Nation Publishing Co. Limited. http://www.nationpublishing.com/advertising/advertising.html (accessed January $8,2011)$.

The University of The West Indies. 2010. "Undergraduate Admissions." University of the West Indies at Cave Hill. October 29.

http://www.cavehill.uwi.edu/admissions/requirements.htm (accessed July 4, 2011).

The World Bank Group. 2009. World Development Indicators Online. www.world bank .org accessed via FIU Library http://library.fiu.edu (accessed June 1, 2010).

Tinker, Irene. 2004. "Challenging Wisdom, Changing Policies: The Women in Development Movement." In Developing Power: How Women Transformed International Development, edited by Arvonne S. Fraser and Irene Tinker. New York: The Feminist Press at the City University of New York.

Tunåker, Carin. 2011. "The Matrifocal Household: Santería Religious Practice and Gender Relations Explored. Graduate Journal of Social Science, 8, no. 2 (October): 137-138. Ipswich, MA: EBSCO.

Turner, J. C., and K. J. Reynolds. 2010. "The Story of Social Identity." In Rediscovering Social Identity: Core Sources.Edited by T. Postmes and N Banscome. Psychology Press.

UNESCO Bangkok. 2005. Exploring and Understanding Gender in Education: A Qualitative Research Manual for Education Practitioners and Gender Focal Points. Bangkok, Thailand: UNESCO Asia and Pacific Regional Bureau for Education.

United Nations. 1976. Report of the World Conference of the International Women's Year, Mexico City, 19 June - 2 July, 1975 (E/Conf.66/34). New York: United Nations. 
-. 1980. Convention on the Elimination of All Forms of Discrimination Against Women, GA res. 34/180, 34 UN GAOR Supp. (No. 46) at 193, UN Doc. A/34/46; 1249 UNTS 13; 19 ILM 33. New York: United Nations.

- 1995. Report of the Fourth World Conference on Women, Beijing, 4-15 September 1995 (A/CONF.177/20/Rev.1. New York: United Nations.

-. 1997. Report of the Economic and Social Council for 1997 (A/52/3). Report to the General Assembly of the United Nations. New York: United Nations.

-.2006. Charter of the United Nations and Statute of the International Court of Justice. Vol. Reprint. New York: United Nations Department of Public Information.

United Nations Development Fund for Women (UNIFEM). 2007. CEDAW and the Human Rights Based Approach to Programming: A UNIFEM Guide. New York: UNIFEM.

United Nations Development Programme. 1997. Human Development Report 1997: Human Development to Eradicate Poverty. New York: United Nations Development Programme —. 2002. Human Development Report 2002: Deepening Democracy in a Fragmented World. New York: UNDP.

—. 2005. Human Development Report 2005: International Coooperation at a Crossroads: Aid, Trade and Security in an Unequal World. New York: UNDP.

-. 2007. Human Development Report 2007/2008: Fighting Climate Change: Human Solidarity in a Divided World.New York: Palgrave Macmillan. —. 2009. Human Development Report 2009: Overcoming Barriers: Human Mobility and Development. New York: Palgrave MacMillan for the United Nations Development Programme.

-. 2010a.Human Development Report 2010: The Real Wealth of Nations: Pathways to Human Development. New York: United Nations Development Programme.

—. 2010b. Women's Empowerment. http://www.undp.org/women (accessed July $18,2010)$.

United Nations Educational, Scientific and Cultural Organization . 2003. Gender and Education for All: The Leap to Equality. Education for All Global Monitorin Report 2003/2004, Paris: UNESCO. 
—. 2011.Employment For All Global Monitoring Report 2011 - The Hidden

Crisis: Armed Conflict and Education. Paris: UNESCO

United Nations Office on Drugs and Crime and World Bank - Latin America and Caribbean Regional Office. 2007. Crime, Violence and Development: Trends, Costs and Policy Options in the Caribbean. Report 37820. UNODC.

United Nations Statistics Division. 2008. Official List of MDG Indicators. January 15. Accessed June 9, 2011.

http://unstats.un.org/unsd/mdg/Host.aspx?Content=Indicators/OfficialList.htm.

—.2010. "Barbados Country Profile." UNdata.Accessed July 18, 2010. http://data.un.org .

—. 2011. "Table 6a: Women in Parliament." Statistics and Indicators on Women and Men. June. Accessed August 10, 2011. unstats.un.org.

United Nations, Department of Economic and Social Affairs, Population Division. 2011.World Population Prospects: The 2010 Revision, CD ROM Edition..

United States Agency for International Development. 2005. Education Strategy: Improving Lives Through Learning. USAID, Washington, D.C.: USAID.

United States Central Intelligence Agency. 2010. CIA World Factbook.Accessed Jukly 18, 2011. https://www.cia.gov/library/publications/the-world-factbook/.

United States Department of State. 2010. "Background Note: Barbados." U.S. Department of State: Diplomacy in Action. July 14.Accessed July 20, 2010. http://www.state.gov.

Vassel, Linette. 2003. "Women, Power and Decision-Making in CARICOM Countries: Moving Forward from a Post Beijing Assessment." In Gender Equality in the Caribbean: Reality or Illusion?, edited by Gemma Tang and Barbara Bailey. Kingston, Jamaica: Ian Randle (in collaboration with CARICOM and UNIFEM)

Visvanathan, Nalini. 1997. "General Introduction." In The Women, Gender and Development Reader, edited by Nalini Visvanathan, Lynn Duggan, Laurie Nisonoff and Nan Wiegersma. London, UK; New Jersey, USA: Zed Books.

Wagstaff, Adam. 2011. "Whither the Development Agency's Flagship Report?" Let's Talk Development: A Blog Hosted by the World Banks Chief Economist. January 25. Accessed June 9, 2011. http://blogs.worldbank.org/developmenttalk/whitherthe-development-agency-s-flagship-report.

Waldrond, E. R. "Mickey". 2000. "Co-ed More than Gender Equality." Daily Nation, 24 April: 9. 
White, Sarah C. 1997. "Men, Masculinities and the Politics of Development." Gender and Development 5, no. Taylor \& Francis on behalf of Oxfam Great Britain.

Wickham, Peter. 2001. "People \& Things: Women in Control." Daily Nation, March 21: $8 \mathrm{~A}$.

Wiley, James. 1998."Dominica's Economic Diversification: Microstates in a Neoliberal Era?" In Globalization and Neoliberalism: The Caribbean Context, edited by Thomas Klak. Lanham; Boulder; New York; Oxford: Rowman \& Littlefield.

Wilkie, Angus. 2000. "From Co-ed to Crisis." Sunday Sun, April 23: 6A.

—. 2006. "What Gender Equality?" Sunday Sun, November 5: 6A.

—. 2007. "Boys on Block Need More Opportunities." Daily Nation, August 22: $10 \mathrm{~A}$.

Wilson, Julie. 2001. "Educators in Support of Co-ed." Weekend Nation, January 19: 16.

Wiltshire-Brodber, Rosina. 1988. "Gender, Race and Class in the Caribbean." In Gender in Caribbean Development: Papers Presented at the Inaugural Seminar of the University of the West Indies Women and Development Studies Project, edited by Patricia Mohammed and Catherine Shepherd. Mona, Jamaica; St. Augustine, Trinidad; Cavehill, Barbados: The UWI Women and Development Studies Project.

Yearwood, Terrel. 2001. "Too Focused on Women." Daily Nation, January 25: 5. 
APPENDICES 
1. Request for Information from Barbados Ministry of Education

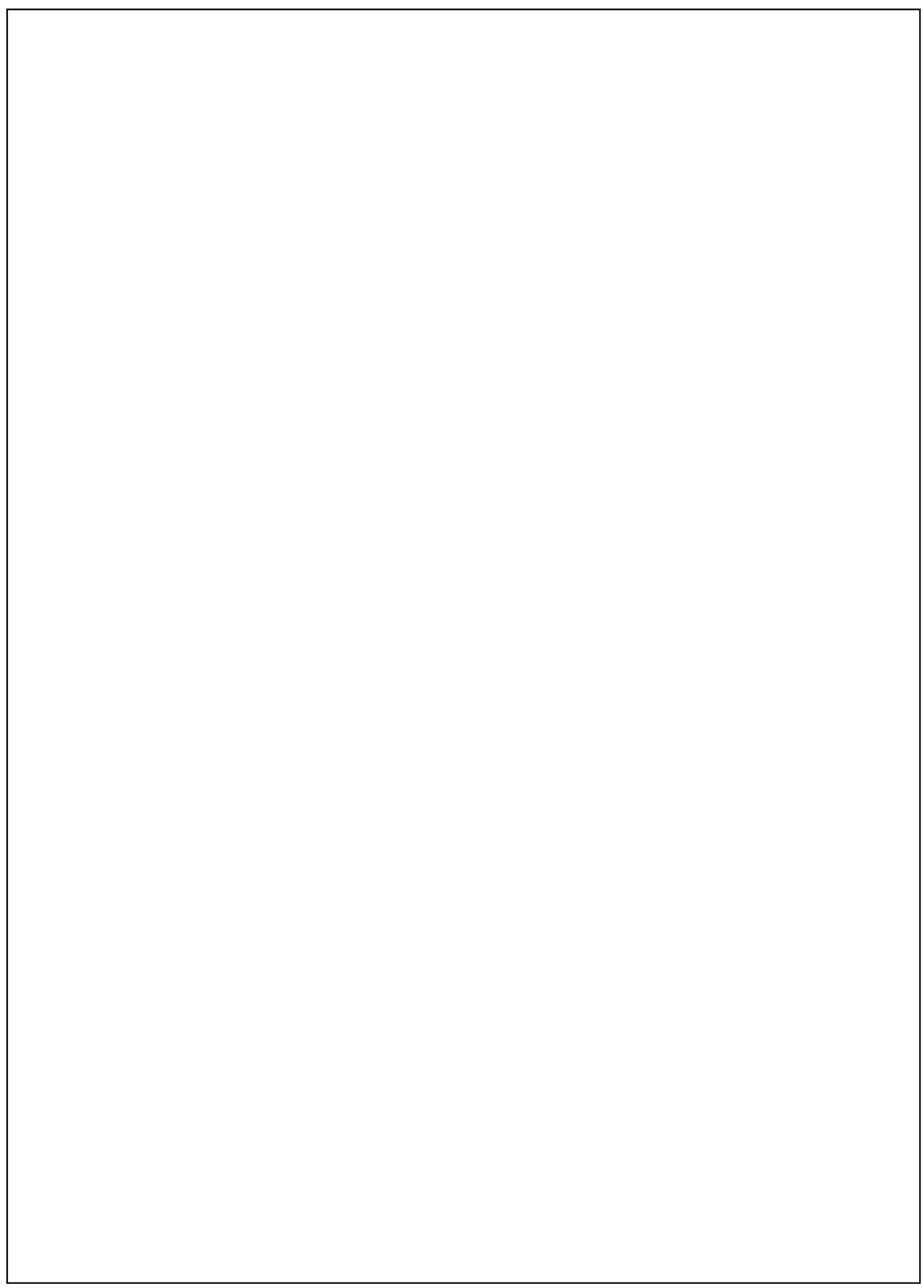




\section{Information Received from the Barbados Ministry of Education}

\section{COMPILATION OF STATISTICS}

$\underline{\text { Male and Female Ratios: Primary, Secondary, Vocational, and Tertiary }}$

\begin{tabular}{|c|c|c|c|}
\hline \multicolumn{5}{|c|}{ Public Nursery and Primary Schools Enrollment* } \\
\hline Year & Male & Female & Total \\
\hline $1990-1991$ & 13686 & 13523 & $\mathbf{2 7 2 0 9}$ \\
\hline $1991-1992$ & 13180 & 14042 & $\mathbf{2 7 2 2 2}$ \\
\hline $1992-1993$ & 13646 & 13212 & $\mathbf{2 6 8 5 8}$ \\
\hline $1993-1994$ & 13557 & 12980 & $\mathbf{2 6 5 3 7}$ \\
\hline $1994-1995$ & 12808 & 13097 & $\mathbf{2 5 9 0 5}$ \\
\hline $1995-1996$ & 13361 & 13100 & $\mathbf{2 6 4 6 5 9}$ \\
\hline $1997 / 1998$ & 13576 & 13083 & $\mathbf{2 6 5 8 0}$ \\
\hline $1998 / 1999$ & 13477 & 13103 & $\mathbf{2 6 6 2 7}$ \\
\hline $1999 / 2000$ & 13538 & 13089 & $\mathbf{2 6 0 6 9}$ \\
\hline $2000 / 2001$ & 13221 & 12848 & $\mathbf{2 5 7 2 1}$ \\
\hline $2001 / 2002$ & 13069 & 12652 & $\mathbf{2 4 8 2 4}$ \\
\hline $2002 / 2003$ & 12923 & 12368 & $\mathbf{2 4 6 7 3}$ \\
\hline $2003 / 2004$ & 12674 & 12150 & $\mathbf{2 5 0 9 7}$ \\
\hline $2004 / 2005$ & 12547 & 12126 & $\mathbf{2 5 3 9 6}$ \\
\hline $2005 / 2006$ & 12840 & 12257 & $\mathbf{2 5 3 6 8}$ \\
\hline $2006 / 2007$ & 12978 & 12414 & $\mathbf{2 5 2 8 2}$ \\
\hline $2007 / 2008$ & 12942 & 12426 & \\
\hline $2008 / 2009$ & 12905 & 12380 & \\
\hline
\end{tabular}

*Includes Special Schools and Special Units

\begin{tabular}{|c|c|c|c|}
\hline \multicolumn{5}{|c|}{ Public Secondary Schools Enrollment } \\
\hline Year & Male & Female & Total \\
\hline $1990-1991$ & 10374 & 11279 & $\mathbf{2 1 6 5 3}$ \\
\hline $1991-1992$ & 10735 & 11177 & $\mathbf{2 1 9 1 2}$ \\
\hline $1992-1993$ & 10608 & 10638 & $\mathbf{2 1 2 4 6}$ \\
\hline $1993-1994$ & 10685 & 10793 & $\mathbf{2 1 4 7 8}$ \\
\hline $1994-1995$ & 10775 & 10753 & $\mathbf{2 1 6 3 2}$ \\
\hline $1995-1996$ & 10804 & 10828 & $\mathbf{2 1 7 0 8}$ \\
\hline $1996 / 1997$ & 10826 & 10882 & $\mathbf{2 1 6 1 7}$ \\
\hline $1997 / 1998$ & 10684 & 10933 & $\mathbf{2 0 4 2 3}$ \\
\hline $1998 / 1999$ & 10558 & 10675 & $\mathbf{2 0 1 9 1}$ \\
\hline $1999 / 2000$ & 10172 & 10251 & $\mathbf{2 0 2 0 4}$ \\
\hline $2000 / 2001$ & 10277 & 9914 & $\mathbf{2 0 3 7 5}$ \\
\hline $2001 / 2002$ & 10278 & 9926 & $\mathbf{2 0 8 4 8}$ \\
\hline $2002 / 2003$ & 10323 & 10052 & $\mathbf{2 0 8 5 9}$ \\
\hline $2003 / 2004$ & 10617 & 10231 & $\mathbf{2 0 4 7 0}$ \\
\hline $2004 / 2005$ & 10729 & 10130 & $\mathbf{1 9 9 5 5}$ \\
\hline $2005 / 2006$ & 10361 & 10109 & $\mathbf{1 9 6 9 4}$ \\
\hline $2006 / 2007$ & 10339 & 9942 & 9883 \\
\hline $2007 / 2008$ & 10072 & 9718 & \\
\hline $2008 / 2009$ & 9976 & &
\end{tabular}


$\underline{\text { Male and Female Teachers: Primary and Secondary }}$

Public Pre-Primary \& Primary Teachers

\begin{tabular}{|c|c|c|c|}
\hline Year & Males & Females & Total \\
\hline $1995 / 1996$ & 311 & 1060 & 1371 \\
\hline $1996 / 1997$ & 343 & 1171 & 1514 \\
\hline $1997 / 1998$ & 350 & 1185 & 1535 \\
\hline $1998 / 1999$ & 348 & 1179 & 1527 \\
\hline $1999 / 2000$ & 340 & 1208 & 1548 \\
\hline $2000 / 2001$ & 335 & 1200 & 1535 \\
\hline $2001 / 2002$ & 355 & 1228 & 1583 \\
\hline $2002 / 2003$ & 341 & 1224 & 1565 \\
\hline $2003 / 2004$ & 329 & 1205 & 1534 \\
\hline $2004 / 2005$ & 336 & 1254 & 1590 \\
\hline $2005 / 2006$ & 316 & 1275 & 1591 \\
\hline $2006 / 2007$ & 315 & 1308 & 1623 \\
\hline $2007 / 2008$ & 326 & 1433 & 1759 \\
\hline $2008 / 2009$ & 344 & 1400 & 1744 \\
\hline
\end{tabular}

\begin{tabular}{|c|c|c|c|}
\hline \multicolumn{5}{|c|}{ Public Secondary Teachers } \\
\hline Year & Males & Females & Total \\
\hline $1997 / 1998$ & 564 & 729 & $\mathbf{1 2 9 3}$ \\
\hline $1998 / 1999$ & 575 & 719 & $\mathbf{1 2 9 4}$ \\
\hline $1999 / 2000$ & 564 & 740 & $\mathbf{1 3 0 4}$ \\
\hline $2000 / 2001$ & 553 & 719 & $\mathbf{1 2 7 2}$ \\
\hline
\end{tabular}




\begin{tabular}{|c|c|c|c|}
\hline $2001 / 2002$ & 551 & 737 & $\mathbf{1 2 8 8}$ \\
\hline $2002 / 2003$ & 537 & 755 & $\mathbf{1 2 9 2}$ \\
\hline $2003 / 2004$ & 497 & 711 & $\mathbf{1 2 0 8}$ \\
\hline $2004 / 2005$ & 537 & 763 & $\mathbf{1 3 0 0}$ \\
\hline $2005 / 2006$ & 535 & 750 & 1285 \\
\hline $2006 / 2007$ & 515 & 774 & 1289 \\
\hline $2007 / 2008$ & 586 & 825 & 1441 \\
\hline $2008 / 2009$ & 553 & 799 & 1352 \\
\hline
\end{tabular}

\begin{tabular}{|c|c|c|c|c|c|c|}
\hline \multicolumn{7}{|c|}{ Tertiary Enrollment } \\
\hline$\underline{\text { Year }}$ & Gender & $\underline{\mathrm{BCC}}$ & Erdiston & $\underline{\text { SJPP }}$ & $\underline{\text { UWI }}$ & TOTAL \\
\hline \multirow[t]{3}{*}{ 1990/91 } & $\mathrm{M}$ & 915 & - & - & - & 915 \\
\hline & $\mathrm{F}$ & 1467 & - & - & - & 1467 \\
\hline & $\mathbf{T}$ & 2382 & 168 & 1723 & 2408 & 6681 \\
\hline \multirow[t]{3}{*}{ 1991/92 } & $\mathrm{M}$ & 891 & - & - & - & 891 \\
\hline & $\mathrm{F}$ & 1643 & - & - & - & 1643 \\
\hline & $\mathbf{T}$ & 2534 & 145 & 1629 & 2580 & 6888 \\
\hline \multirow[t]{3}{*}{$1992 / 93$} & $\mathrm{M}$ & 777 & 72 & 611 & 1024 & 2484 \\
\hline & $\mathrm{F}$ & 1423 & 22 & 775 & 1548 & 3768 \\
\hline & $\mathbf{T}$ & 2200 & 94 & 1386 & 2572 & 6252 \\
\hline \multirow[t]{3}{*}{ 1993/94 } & M & 790 & - & - & - & 790 \\
\hline & $\mathrm{F}$ & 1496 & - & - & - & 1496 \\
\hline & $\mathbf{T}$ & 2286 & 573 & 1500 & 2811 & 7170 \\
\hline \multirow[t]{2}{*}{$1994 / 95$} & $\mathrm{M}$ & 835 & - & 385 & - & 1220 \\
\hline & $\mathrm{F}$ & 1705 & - & 1006 & - & 2711 \\
\hline
\end{tabular}




\begin{tabular}{|c|c|c|c|c|c|c|}
\hline \multicolumn{7}{|c|}{ Tertiary Enrollment } \\
\hline \multirow[t]{2}{*}{ Year } & Gender & $\underline{\mathrm{BCC}}$ & Erdiston & $\underline{\text { SJPP }}$ & $\underline{\text { UWI }}$ & TOTAL \\
\hline & $\mathbf{T}$ & 2540 & 400 & 1394 & 2883 & 7214 \\
\hline \multirow[t]{3}{*}{ 1995/96 } & $\mathrm{M}$ & 993 & 37 & 1242 & 1187 & 3459 \\
\hline & $\mathrm{F}$ & 1790 & 126 & 679 & 1929 & 4524 \\
\hline & $\mathbf{T}$ & 2783 & 163 & 1921 & 3116 & 7983 \\
\hline \multirow[t]{3}{*}{$1996 / 97$} & M & 1044 & 44 & 1323 & 1195 & 3606 \\
\hline & $\mathrm{F}$ & 1950 & 131 & 976 & 2038 & 5095 \\
\hline & $\mathbf{T}$ & 2994 & 175 & 2299 & 3233 & 8701 \\
\hline \multirow[t]{3}{*}{ 1997/98 } & $\mathrm{M}$ & 1019 & 57 & 1457 & 1334 & 3867 \\
\hline & $\mathrm{F}$ & 1834 & 119 & 835 & 2234 & 5022 \\
\hline & $\mathbf{T}$ & 2853 & 176 & 2292 & 3568 & 8889 \\
\hline \multirow[t]{3}{*}{ 1998/99 } & $\mathrm{M}$ & 1344 & 44 & 1335 & 1273 & 3996 \\
\hline & $\mathrm{F}$ & 2454 & 86 & 937 & 2368 & 5845 \\
\hline & $\mathbf{T}$ & 3798 & 130 & 2272 & 3641 & 9841 \\
\hline \multirow[t]{3}{*}{$1999 / 00$} & $\mathrm{M}$ & 1131 & 28 & 1596 & 1425 & 4180 \\
\hline & $\mathrm{F}$ & 2409 & 65 & 908 & 2570 & 5952 \\
\hline & $\mathbf{T}$ & 3540 & 93 & 2404 & 3995 & 10132 \\
\hline \multirow[t]{3}{*}{$2000 / 01$} & M & 1288 & 32 & 1571 & 1334 & 4225 \\
\hline & $\mathrm{F}$ & 2556 & 76 & 1250 & 2604 & 6486 \\
\hline & $\mathbf{T}$ & 3844 & 108 & 2821 & 3938 & 10711 \\
\hline \multirow[t]{3}{*}{$2001 / 02$} & $\mathrm{M}$ & 1228 & 22 & 1679 & 1310 & 4239 \\
\hline & $\mathrm{F}$ & 2455 & 72 & 1294 & 2672 & 6493 \\
\hline & $\mathbf{T}$ & 3683 & 94 & 2973 & 3982 & 10732 \\
\hline \multirow[t]{2}{*}{$2002 / 03$} & $\mathrm{M}$ & 1277 & 93 & 1498 & 1436 & 4304 \\
\hline & $\mathrm{F}$ & 2420 & 130 & 1474 & 2927 & 6951 \\
\hline
\end{tabular}




\begin{tabular}{|c|c|c|c|c|c|c|}
\hline \multicolumn{7}{|c|}{ Tertiary Enrollment } \\
\hline \multirow[t]{2}{*}{ Year } & $\underline{\text { Gender }}$ & $\underline{\mathrm{BCC}}$ & Erdiston & $\underline{\text { SJPP }}$ & $\underline{\text { UWI }}$ & TOTAL \\
\hline & $\mathbf{T}$ & 3697 & 223 & 2972 & 4363 & 11255 \\
\hline \multirow[t]{3}{*}{ 2003/04 } & $M$ & 1116 & 37 & 1593 & 1589 & 4335 \\
\hline & $\mathrm{F}$ & 2332 & 126 & 1351 & 3315 & 7124 \\
\hline & $\mathbf{T}$ & 3448 & 163 & 2944 & 4904 & 11459 \\
\hline \multirow[t]{3}{*}{ 2004/05 } & $\mathrm{M}$ & 1429 & 32 & 1726 & 1874 & 5061 \\
\hline & $\mathrm{F}$ & 2685 & 67 & 1110 & 3910 & 7772 \\
\hline & $\mathbf{T}$ & 4114 & 99 & 2836 & 5784 & 12833 \\
\hline \multirow[t]{3}{*}{$2005 / 06$} & $\mathrm{M}$ & 1326 & 50 & 1524 & 1948 & 4848 \\
\hline & $F$ & 2539 & 138 & 1248 & 4266 & 8191 \\
\hline & $\mathbf{T}$ & 3865 & 188 & 2772 & 6214 & 13039 \\
\hline \multirow[t]{3}{*}{ 2006/07 } & $\mathrm{M}$ & 1402 & 49 & 1632 & 2193 & 5276 \\
\hline & $\mathrm{F}$ & 2886 & 192 & 1516 & 4642 & 9236 \\
\hline & $T$ & 4288 & 241 & 3148 & 6835 & 14512 \\
\hline \multirow[t]{3}{*}{$2007 / 08$} & $\mathrm{M}$ & 1459 & 74 & 1360 & 2310 & 5203 \\
\hline & $\mathrm{F}$ & 3001 & 227 & 1512 & 5001 & 9741 \\
\hline & $\mathbf{T}$ & 4460 & 301 & 2872 & 7311 & 14944 \\
\hline \multirow[t]{3}{*}{ 2008/09 } & $\mathrm{M}$ & 1406 & 67 & 1648 & 2495 & 5616 \\
\hline & $F$ & 3170 & 222 & 1239 & 5286 & 9917 \\
\hline & $\mathbf{T}$ & 4576 & 289 & 2887 & 7781 & 15533 \\
\hline
\end{tabular}


Tertiary Graduates by Gender 2008/2009

\begin{tabular}{|c|c|c|c|c|c|c|}
\hline \multicolumn{7}{|c|}{ Tertiary Graduates by Gender 2008/2009 } \\
\hline Year & Gender & $\begin{array}{l}\text { Barbados } \\
\text { Community } \\
\text { College }\end{array}$ & $\begin{array}{l}\text { Erdiston } \\
\text { Teachers } \\
\text { Training } \\
\text { College }\end{array}$ & $\begin{array}{l}\text { Samuel } \\
\text { Jackman } \\
\text { Prescod } \\
\text { Polytechnic }\end{array}$ & $\begin{array}{l}\text { University of } \\
\text { West Indies } \\
\text { (Cave Hill) }\end{array}$ & TOTAL \\
\hline $2008 /$ & Male & 328 & 57 & 78 & 396 & 859 \\
\hline \multirow[t]{2}{*}{09} & Female & 580 & 158 & 112 & 1117 & 1967 \\
\hline & $\begin{array}{l}\text { TOTA } \\
\mathrm{L}\end{array}$ & 908 & 215 & 190 & 1513 & $\underline{2826}$ \\
\hline
\end{tabular}

Barbados Secondary Schools' Entrance Examination (BSSEE)

\begin{tabular}{|c|c|c|c|}
\hline \hline YEAR & MALE & FEMALE & TOTAL \\
\hline $\mathbf{1 9 9 9}$ & 1852 & 1759 & $\mathbf{3 6 1 1}$ \\
\hline $\mathbf{2 0 0 0}$ & 1979 & 1847 & $\mathbf{3 8 2 6}$ \\
\hline $\mathbf{2 0 0 1}$ & 2085 & 2061 & $\mathbf{4 1 4 6}$ \\
\hline $\mathbf{2 0 0 2}$ & 2033 & 2019 & $\mathbf{4 0 5 2}$ \\
\hline $\mathbf{2 0 0 3}$ & 2078 & 2119 & $\mathbf{4 1 9 7}$ \\
\hline $\mathbf{2 0 0 4}$ & 1986 & 1884 & $\mathbf{3 8 7 0}$ \\
\hline $\mathbf{2 0 0 5}$ & 1764 & 1793 & $\mathbf{3 5 5 7}$ \\
\hline $\mathbf{2 0 0 6}$ & 1832 & 1762 & $\mathbf{3 5 9 4}$ \\
\hline $\mathbf{2 0 0 7}$ & 1752 & 1740 & $\mathbf{3 4 9 2}$ \\
\hline
\end{tabular}




\begin{tabular}{|c|c|c|c|c|c|c|}
\hline \multicolumn{7}{|c|}{ Barbados Vocational Training Board } \\
\hline & \multicolumn{3}{|c|}{$\begin{array}{c}\text { Persons Registered for the Skills } \\
\text { Training Programme }\end{array}$} & \multicolumn{3}{|c|}{ Apprenticeship Programme } \\
\hline & $\mathbf{M}$ & $\mathbf{F}$ & $\mathbf{T}$ & $\mathbf{M}$ & $\mathbf{F}$ & $\mathbf{T}$ \\
\hline $1994-1995$ & 505 & 305 & 810 & 147 & 7 & 154 \\
\hline $1995 / 1996$ & 347 & 229 & 576 & - & - & 143 \\
\hline $1996 / 1997$ & - & - & - & - & - & - \\
\hline $1997 / 1998$ & 429 & 279 & 708 & 171 & 19 & 190 \\
\hline $1998 / 1999$ & 553 & 341 & 894 & 192 & 18 & 210 \\
\hline
\end{tabular}

\begin{tabular}{|c|c|c|c|c|c|c|c|c|c|c|c|}
\hline \multicolumn{12}{|c|}{$\begin{array}{l}\text { CSEC Results by Subject } 1993 \text { [SAMPLE: Results were also provided for the years } \\
1994-2009\}\end{array}$} \\
\hline \multicolumn{3}{|l|}{$\begin{array}{l}\text { Count of } \\
\text { CANDIDATE_NBR }\end{array}$} & \multicolumn{9}{|c|}{ OVERALL_GRADE } \\
\hline SUBJECT & PROFICIENCY & SEX & 1 & 2 & 3 & 4 & 5 & A & $\mathrm{U}$ & (blank) & $\begin{array}{l}\text { Grand } \\
\text { Total }\end{array}$ \\
\hline \multirow[t]{2}{*}{$\begin{array}{l}\text { *AGRICULTURAL } \\
\text { SCIENCE DA }\end{array}$} & \multirow[t]{2}{*}{ G } & $\mathrm{F}$ & & 1 & 14 & & & & & 1 & 16 \\
\hline & & M & & 2 & 23 & 7 & 2 & & & 2 & 36 \\
\hline $\begin{array}{l}\text { *INTEGRATED } \\
\text { SCIFNCE DA }\end{array}$ & $G$ & $F$ & & & & & & & & 2 & 2 \\
\hline \multirow[t]{2}{*}{$\begin{array}{l}\text { AGRICULTURAL } \\
\text { SCIENCE(CS) }\end{array}$} & G & $\mathrm{F}$ & 1 & 10 & 26 & 8 & & & & 1 & 46 \\
\hline & & M & 1 & 12 & 17 & 4 & & & & 2 & 36 \\
\hline \multirow[t]{2}{*}{ ART } & G & $\mathrm{F}$ & 4 & 11 & 4 & 2 & & 1 & 1 & & 23 \\
\hline & & M & 25 & 47 & 17 & 6 & 2 & 13 & 6 & & 116 \\
\hline \multirow[t]{2}{*}{ ART \& CRAFT } & G & $\mathrm{F}$ & 14 & 58 & 14 & 3 & 7 & 10 & 8 & & 114 \\
\hline & & M & 12 & 58 & 27 & 6 & 2 & 21 & 6 & & 132 \\
\hline \multirow[t]{2}{*}{ BIOLOGY } & G & $\mathrm{F}$ & 42 & 191 & 173 & 41 & 2 & & & 6 & 455 \\
\hline & & M & 22 & 100 & 107 & 15 & 1 & & & 6 & 251 \\
\hline \multirow[t]{2}{*}{ BOOKKEEPING } & B & $\mathrm{F}$ & 7 & 39 & 38 & 27 & 6 & & & 5 & 122 \\
\hline & & M & 6 & 8 & 16 & 4 & & & & 6 & 40 \\
\hline \multirow[t]{2}{*}{$\begin{array}{l}\text { BUILDING } \\
\text { TECHNOLOGY }\end{array}$} & $\mathrm{T}$ & $\mathrm{F}$ & & & & & & & & 1 & 1 \\
\hline & & M & & 6 & 7 & 2 & & & & & 15 \\
\hline
\end{tabular}




\begin{tabular}{|c|c|c|c|c|c|c|c|c|c|c|}
\hline \multirow[t]{4}{*}{ CARIBBEAN HISTORY } & B & $\mathrm{F}$ & 1 & 20 & 14 & 7 & & & 2 & 44 \\
\hline & & M & 1 & 12 & 10 & 3 & & & 3 & 29 \\
\hline & $\mathrm{G}$ & $\mathrm{F}$ & 112 & 132 & 83 & 36 & 1 & & 7 & 371 \\
\hline & & $\mathrm{M}$ & 45 & 85 & 67 & 42 & 5 & & 12 & 256 \\
\hline \multirow[t]{2}{*}{ CHEMISTRY } & G & $\mathrm{F}$ & 30 & 125 & 64 & 27 & 1 & & 1 & 248 \\
\hline & & M & 33 & 94 & 61 & 25 & 1 & 1 & 3 & 218 \\
\hline \multirow[t]{4}{*}{$\begin{array}{l}\text { CLOTHING \& } \\
\text { TEXTILES }\end{array}$} & B & $\mathrm{F}$ & 13 & 9 & 4 & & & & 1 & 27 \\
\hline & & $\mathrm{M}$ & & 1 & & & & & 1 & 2 \\
\hline & $\mathrm{G}$ & $\mathrm{F}$ & 8 & 42 & 5 & 2 & & & 3 & 60 \\
\hline & & M & & 5 & & & & & & 5 \\
\hline \multirow[t]{2}{*}{ CRAFT } & G & $\mathrm{F}$ & 23 & 36 & 8 & & & 10 & 4 & 81 \\
\hline & & $\mathrm{M}$ & 19 & 42 & 8 & 3 & & & 7 & 86 \\
\hline \multirow[t]{3}{*}{$\begin{array}{l}\text { ELECTRICITY/ } \\
\text { ELECTRONICS }\end{array}$} & $\mathrm{B}$ & $\mathrm{M}$ & 4 & 8 & 6 & 4 & 5 & & 9 & 36 \\
\hline & G & $\mathrm{F}$ & & 1 & 2 & & & & 1 & 4 \\
\hline & & M & & 16 & 21 & 5 & & 1 & 2 & 45 \\
\hline \multirow[t]{4}{*}{ ENGLISH (A) } & B & $\mathrm{F}$ & 23 & 118 & 137 & 89 & 9 & & 14 & 390 \\
\hline & & M & 28 & 99 & 92 & 90 & 12 & & 14 & 335 \\
\hline & G & $\mathrm{F}$ & 142 & 464 & 474 & 163 & & 1 & 22 & 1266 \\
\hline & & M & 71 & 248 & 375 & 153 & 5 & & 23 & 875 \\
\hline \multirow[t]{2}{*}{ ENGLISH (B) } & G & $\mathrm{F}$ & 151 & 257 & 160 & 30 & 8 & & 7 & 613 \\
\hline & & $\mathrm{M}$ & 67 & 170 & 115 & 16 & 2 & & 7 & 377 \\
\hline \multirow[t]{4}{*}{ FOOD \& NUTRITION } & B & $\mathrm{F}$ & 5 & 15 & 1 & & & & 3 & 24 \\
\hline & & M & 1 & 1 & & & & & & 2 \\
\hline & $\mathrm{G}$ & $\mathrm{F}$ & 40 & 119 & 32 & 5 & & & 7 & 203 \\
\hline & & $\mathrm{M}$ & 2 & 21 & 8 & 1 & & & 2 & 34 \\
\hline \multirow[t]{4}{*}{ FRENCH } & B & $\mathrm{F}$ & 3 & 22 & 32 & 25 & 19 & & 11 & 112 \\
\hline & & $\mathrm{M}$ & 2 & 18 & 11 & 4 & 4 & & 7 & 46 \\
\hline & $\mathrm{G}$ & $\mathrm{F}$ & 33 & 98 & 109 & 50 & 3 & & 3 & 296 \\
\hline & & $\mathrm{M}$ & 11 & 33 & 38 & 20 & 2 & & 3 & 107 \\
\hline \multirow[t]{4}{*}{ GEOGRAPHY } & B & $\mathrm{F}$ & 1 & 20 & 32 & 21 & 1 & & 4 & 79 \\
\hline & & $\mathrm{M}$ & 3 & 34 & 18 & 10 & 2 & & 4 & 71 \\
\hline & $\mathrm{G}$ & $\mathrm{F}$ & 44 & 149 & 121 & 25 & & & 4 & 343 \\
\hline & & $\mathrm{M}$ & 42 & 220 & 113 & 28 & 4 & & 7 & 414 \\
\hline \multirow[t]{4}{*}{$\begin{array}{l}\text { HOME ECON. } \\
\text { MANAGEMENT }\end{array}$} & B & $\mathrm{F}$ & 3 & 11 & 2 & 1 & & & 1 & 18 \\
\hline & & $\mathrm{M}$ & & & 1 & & & & 1 & 2 \\
\hline & $\mathrm{G}$ & $\mathrm{F}$ & 7 & 21 & 9 & & & & 2 & 39 \\
\hline & & $\mathrm{M}$ & 1 & 6 & 4 & & & & & 11 \\
\hline \multirow[t]{3}{*}{$\begin{array}{l}\text { INFORMATION } \\
\text { TECHNOLOGY }\end{array}$} & $\mathrm{G}$ & $\mathrm{F}$ & & & 1 & 16 & 10 & 1 & 1 & 29 \\
\hline & & $\mathrm{M}$ & 1 & 1 & 10 & 10 & 6 & & & 28 \\
\hline & $\mathrm{T}$ & $\mathrm{F}$ & 8 & 28 & 21 & 9 & & 2 & 4 & 72 \\
\hline
\end{tabular}




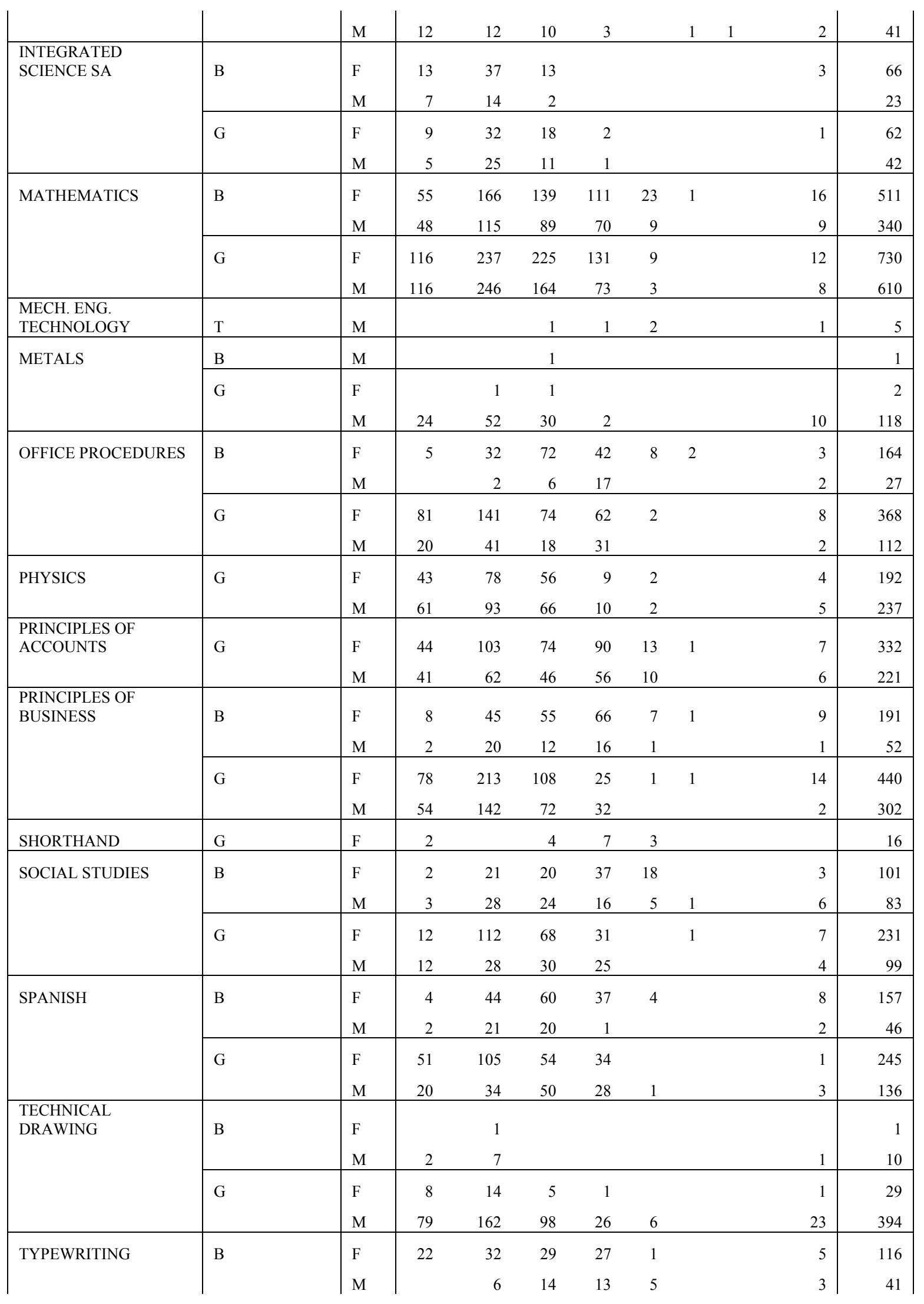




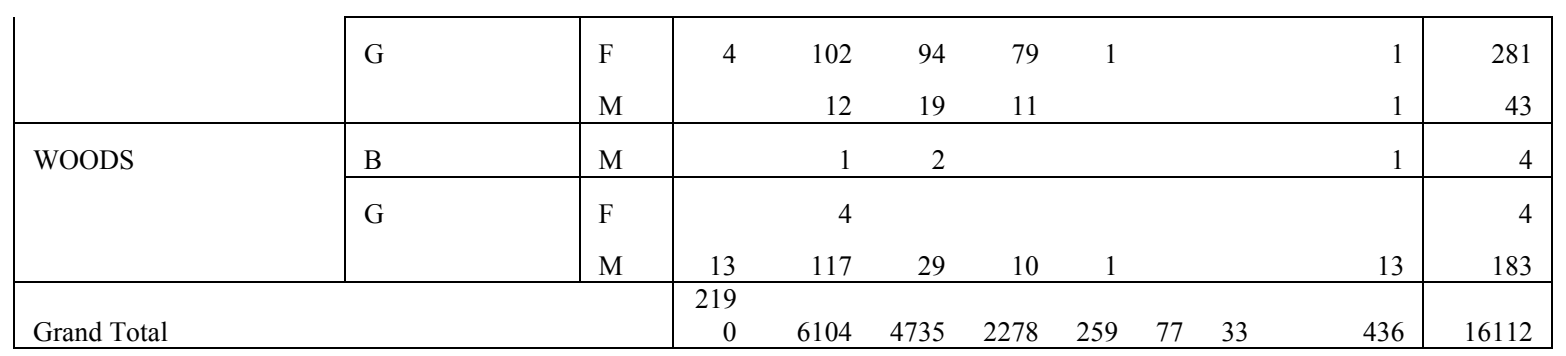




\section{International Standard Industrial Classification of all Economic Activities (ISIC-Rev.2, 1968) ${ }^{18}$}

\section{Major Division 1. Agriculture, Hunting, Forestry and Fishing}

11. Agriculture and Hunting

111. Agricultural and livestock production

112. Agricultural services

113. Hunting, trapping and game propagation

12. Forestry and Logging

121. Forestry

122. Logging

13.

130. Fishing

\section{Major Division 2. Mining and Quarrying}

21.

210. Coal Mining

22.

220. Crude Petroleum and Natural Gas Production

23.

230. Metal Ore Mining

29.

290. Other Mining

\section{Major Division 3. Manufacturing}

31. Manufacture of Food, Beverages and Tobacco

311-312. Food manufacturing

313. Beverage industries

314. Tobacco manufactures

32. Textile, Wearing Apparel and Leather Industries

321. Manufacture of textiles

322. Manufacture of wearing apparel, except footwear

323. Manufacture of leather and products of leather, leather substitutes and fur, except footwear and wearing apparel

324. Manufacture of footwear, except vulcanized or moulded rubber or plastic footwear

33. Manufacture of Wood and Wood Products, Including Furniture

331. Manufacture of wood and wood and cork products, except furniture

332. Manufacture of furniture and fixtures, except primarily of metal

34. Manufacture of Paper and Paper Products, Printing and Publishing

\footnotetext{
${ }^{18}$ This Classification consists of Major Divisions (one-digit codes), Divisions (two-digit codes), Major Groups (three-digit codes) and Groups (four-digit codes); the last are not shown separately in this Appendix. For full details see United Nations (1968), Statistical Papers, Series M, No. 4, rev. 2. United Nations: New York
} 
341. Manufacture of paper and paper products

342. Printing, publishing and allied industries

35. Manufacture of Chemicals and Chemical, Petroleum, Coal, Rubber and Plastic

Products

351. Manufacture of industrial chemicals

352. Manufacture of other chemical products

353. Petroleum refineries

354. Manufacture of miscellaneous products of petroleum and coal

355. Manufacture of rubber products

356. Manufacture of plastic products not elsewhere classified

36. Manufacture of Non-Metallic Mineral Products, except Products of Petroleum and Coal

361. Manufacture of pottery, china and earthenware

362. Manufacture of glass and glass products

369. Manufacture of other non-metallic mineral products

37. Basic Metal Industries

371. Iron and steel basic industries

372. Non-ferrous metal basic industries

38. Manufacture of Fabricated Metal Products, Machinery and Equipment

381. Manufacture of fabricated metal products, except machinery and equipment

382. Manufacture of machinery except electrical

383. Manufacture of electrical machinery apparatus, appliances and supplies

384. Manufacture of transport equipment

385. Manufacture of professional and scientific and measuring and controlling

equipment not elsewhere classified, and of photographic and optical goods

39.

390. Other Manufacturing Industries

\section{Major Division 4. Electricity, Gas and Water}

41.

42.

410. Electricity, Gas and Steam

420. Water Works and Supply

\section{Major Division 5. Construction}

50 .

500. Construction

\section{Major Division 6. Wholesale and Retail Trade and Restaurants and Hotels}

61.

610. Wholesale Trade

62.

620. Retail Trade

63. Restaurants and Hotels

631. Restaurants, cafés and other eating and drinking places 
632. Hotels, rooming houses, camps and other lodging places

\section{Major Division 7. Transport, Storage and Communication}

71. Transport and Storage

711. Land transport

712. Water transport

713. Air transport

719. Services allied to transport

72.

720. Communication

\section{Major Division 8. Financing, Insurance, Real Estate and Business Services}

81.

810. Financial Institutions

82.

820. Insurance

83. Real Estate and Business Services

831. Real estate

832. Business services except machinery and equipment rental and leasing

833. Machinery and equipment rental and leasing

\section{Major Division 9. Community, Social and Personal Services}

91.

910. Public Administration and Defence

92.

920. Sanitary and Similar Services

93. Social and Related Community Services

931. Education services

932. Research and scientific institutes

933. Medical, dental, other health and veterinary services

934. Welfare institutions

935. Business, professional and labour associations

939. Other social and related community services

94. Recreational and Cultural Services

941. Motion picture and other entertainment services

942. Libraries, museums, botanical and zoological gardens, and other cultural services not elsewhere classified

949. Amusement and recreational services not elsewhere classified

95. Personal and Household Services

951. Repair services not elsewhere classified

952. Laundries, laundry services, and cleaning and dyeing plants

953. Domestic services

959. Miscellaneous personal services 
96.

960. International and Other Extra-Territorial Bodies

\section{Major Division 0. Activities not Adequately Defined}

00 .

000. Activities not adequately defined 


\section{International Standard Industrial Classification of Occupations (ISCO 88): Summary}

1. Legislators, senior officials and managers

Workers in this group determine and formulate government policies, laws and public regulations, and oversee their implementation. They may also represent governments and act on their behalf, or plan, direct and coordinate the policies and activities of enterprises and organizations, or departments. No skill level is assigned to this group.

\section{Professionals}

Workers in this group require a high level of professional knowledge and experience in the fields of physical and life sciences, or social sciences and humanities. Their main tasks consist of increasing the existing stock of knowledge, applying scientific and artistic concepts and theories to the solution of problems, and teaching about the foregoing in a systematic manner. Most occupations in this major group would require university or post-graduate level education to acquire the necessary skills.

\section{Technicians and associate professionals}

Workers in this group require technical knowledge and experience in one or more fields of physical and life sciences, or social sciences and humanities. The main tasks consist of carrying out technical work connected with the application of concepts and operational methods in these fields, and in teaching at certain educational levels. Most occupations in this major group require post-secondary/tertiary education though not necessarily needing a first-level university degree.

\section{Clerks}

Workers in this group require the knowledge and experience necessary to organize, store, compute and retrieve information. They mainly perform secretarial duties, operate word processors and other office machines, record and compute numerical data, and perform a number of customer-oriented clerical duties, mostly in connection with mail services, money-handling operations and appointments. Workers in this group are likely to need a full course of secondary education as well as some on-the-job training.

\section{Service workers and shop and market sales workers}

Workers in this group provide personal and protective services, and/or sell goods in shops or at markets. Their main tasks include providing services related to travel, housekeeping, catering, personal care, protection of individuals and property, and maintaining law and order, or selling goods in shops or at markets. Workers in this group are likely to need a full course of secondary education as well as some on-the-job training. 


\section{Skilled agricultural and fishery workers}

This major group includes occupations whose tasks require the knowledge and experience to produce farm, forestry and fishery products. The main tasks consist or growing crops, breeding or hunting animals, catching or cultivating fish, conserving and exploiting forests and, especially in the case of market-oriented agricultural and fishery workers, selling products to purchasers, marketing organisations or at markets. Most occupations in this major group require skills at the second ISCO skill level. This major group has been divided into two sub-major groups, six minor groups and 17 unit groups, reflecting differences in tasks associated with differences between market-oriented and subsistence agricultural and fishery workers.

\section{Craft and related trades workers}

This major group includes occupations whose tasks require the knowledge and experience of skilled trades or handicrafts which, among other things, involves an understanding of materials and tools to be used, as well as of all stages of the production process, including the characteristics and the intended use of the final product. The main tasks consist of extracting raw materials, constructing buildings and other structures and making various products as well as handicraft goods. Most occupations in this major group require skills at the second ISCO skill level. This major group has been divided into four sub-major groups, 16 minor groups and 70 unit groups, reflecting differences in tasks associated with different areas of specialisation.

\section{Plant and machine operators and assemblers}

Workers in this group operate and monitor large scale, and often highly automated, industrial machinery and equipment. They mainly operate and monitor mining, processing and production machinery and equipment, as well as drive vehicles, or assemble products from component parts. Workers in this group are likely to need a full course of secondary education as well as some on-the-job training.

\section{Elementary occupations}

Workers in this group perform mostly simple and routine tasks, which involve the use of hand-held tools and in some cases considerable physical effort, and, with few exceptions, only limited personal initiative or judgment. Their main tasks consist of selling goods in streets, door-keeping and property watching, as well as cleaning, washing, pressing, and working as laborers in the fields of mining, agriculture and fishing, construction and manufacturing. Workers in this group are likely to need more than a primary education and require little to no additional training. 


\section{Armed forces}

Members of the armed forces are those personnel who are currently serving in the armed forces, including auxiliary services, whether on a voluntary or compulsory basis, and who are not free to accept civilian employment. Included are regular members of the army, navy, air force and other military services, as well as conscripts enrolled for military training or other service for a specified period, depending on national requirements. Excluded are persons in civilian employment of government establishments concerned with defense issues: police (other than military police); customs inspectors and members of border or other armed civilian services; persons who have been temporarily withdrawn from civilian life for a short period of military training or retraining, according to national requirements, and members of military reserves not currently on active service. Various skill levels may be involved.

Source: (International Labour Organization 2004) 
VITA

April 4, 1980

2000

2002

2000-2002

2002-2004

2003

2004-2006

2005

2006

2006-2011
Born, St. Michael, Barbados

B.A., Organizational Communication/Public Relations The University of Texas at El Paso El Paso Texas

Master of Public Administration

The University of Texas at El Paso

El Paso Texas

Teaching Assistant in Political Science

The University of Texas at El Paso

El Paso Texas

Teaching Assistant in International Relations and Geography Florida International University Miami, Florida

Recipient Latin American and Caribbean Center Scholarship Florida International University

Miami, Florida

Lecturer (Adjunct) in International Relations

Florida International University

Miami, Florida

Graduate Certificate in Latin American and Caribbean Studies Florida International University Latin American and Caribbean Center Miami, Florida

Best Graduate Paper 2005-2006, FIU Department of International Relations \& Geography

Miami, Florida

Doctoral Candidate in International Relations

Florida International University

Miami, Florida 
2008-2009

Associate Social Affairs Officer

United Nations Programme on Youth

Division for Social Policy and Development

United Nations Department of Economic and Social Affairs

New York, New York

2009-2011

Social Affairs Officer

Social Perspective on Development Branch

Division for Social Policy and Development

United Nations Department of Economic and Social Affairs

New York, New York

PUBLICATIONS AND PRESENTATIONS

"Hegemonic Masculinity and the 'Crisis' of the Barbadian Male." - Abriendo Brecha III: Activist Scholarship Conference on Crisis, Politics and Performance in the Americas, February 16-18, 2006, Austin, Texas

"Putting Gender in Place? Hegemonic Masculinity and the 'Crisis' of the Barbadian Male.”- FIU Women's Studies Conference, March 31, 2004, Miami, Florida 